\title{
Ages of 24 widespread tephras erupted since 30,000 years ago in New Zealand, with re-evaluation of the timing and palaeoclimatic implications of the Lateglacial cool episode at Kaipo bog
}

\author{
David J. Lowe ${ }^{\mathrm{a} *}$, Maarten Blaauw ${ }^{\mathrm{b}}$, Alan G. Hogg ${ }^{\mathrm{c}}$, and Rewi M. Newnham ${ }^{\mathrm{d}}$ \\ ${ }^{a}$ Department of Earth and Ocean Sciences, University of Waikato, Private Bag 3105, \\ Hamilton 3240, New Zealand \\ ${ }^{b}$ School of Geography, Archaeology and Palaeoecology, Queen's University Belfast, Belfast \\ Northern Ireland BT7 1NN, UK \\ ${ }^{c}$ Radiocarbon Dating Laboratory, University of Waikato, Private Bag 3105, Hamilton 3240, \\ New Zealand \\ ${ }^{d}$ School of Geography, Environment and Earth Sciences, Victoria University of Wellington, \\ P.O. Box 600, Wellington 6140, New Zealand
}

Quaternary Science Reviews

Australasian INTIMATE issue

Article JQSR_3505 accepted for publication: 21 Nov 2012

http://dx.doi.org/10.1016/j.quascirev.2012.11.022

(available online 19 Feb 2013)

This is final pre-publication manuscript version.

Definitive version is that published by $Q S R$

* Corresponding author. Tel.: +647 838 4438; fax: +647 8560115 .

E-mail address: d.lowe@waikato.ac.nz (D.J. Lowe). 
Contents

\section{Introduction}

1.1. The question of timing of the Lateglacial cool episode at Kaipo bog

2. Age models for 24 marker tephras erupted since 30,000 cal. yr BP

2.1. Wiggle-match dating of two late Holocene tephras using ${ }^{14} \mathrm{C}$ and tree-ring sequences

2.2. Flexible depositional age-modelling of 16 Lateglacial to Holocene tephras at Kaipo peat sequence using Bacon and the IntCal09 data set

2.2.1. Kaipo bog: origin, environment, and tephra-peat section

2.2.2. Flexible depositional age-modelling of 16 tephras at Kaipo using Bacon

2.3. Flexible depositional age-modelling of 16 Lateglacial to Holocene tephras at Kaipo peat sequence using $P \_S e q u e n c e$ function in OxCal4.1.7 and the IntCal09 data set

2.4. Calibrating ages of six Holocene tephras using Tau_Boundary function in OxCal4.1.7 with the SHCal04 and IntCal09 data sets

2.5. Calibrating ages of eight pre-Holocene tephras using using Tau_Boundary function in OxCal4.1.7 and the IntCal09 data set

3. Stratigraphic proximity of tephra marker beds to key climatic changes

4. Timing of the Lateglacial cool episode at Kaipo bog and palaeoclimatic implications

4.1. New ages for the onset and ending of the cool episode derived using Bacon and $P \_$Sequence function in OxCal4.1.7 and the IntCal09 data set

4.2. Palaeoclimatic implications and discussion

\section{Conclusions}

\section{Acknowledgements}

Appendix A. Supplementary data

\section{References}




\section{Abstract}

Tephras are important for the NZ-INTIMATE project because they link all three records comprising the composite inter-regional stratotype developed for the New Zealand climate event stratigraphy (NZ-CES). Here we firstly report new calendar ages for 24 widespread marker tephras erupted since 30,000 calendar (cal.) years ago in New Zealand to help facilitate their use as chronostratigraphic dating tools for the NZ-CES and for other palaeoenvironmental and geological applications. The selected tephras comprise 12 rhyolitic tephras from Taupo, nine rhyolitic tephras from Okataina, one peralkaline rhyolitic tephra from Tuhua, and one andesitic tephra each from Tongariro and Egmont/Taranaki volcanic centres. Age models for the tephras were obtained using three methods: (i) ${ }^{14} \mathrm{C}$-based wigglematch dating of wood from trees killed by volcanic eruptions (these dates published previously); (ii) flexible depositional modelling of a high-resolution ${ }^{14} \mathrm{C}$-dated age-depth sequence at Kaipo bog using two Bayesian-based modelling programs, Bacon and OxCal's $P \_S e q u e n c e$ function, and the IntCal09 data set (with SH offset correction $-44 \pm 17 \mathrm{yr}$ ); and (iii) calibration of ${ }^{14} \mathrm{C}$ ages using OxCal's Tau_Boundary function and the SHCal04 and IntCal09 data sets. Our preferred dates or calibrated ages for the 24 tephras are as follows (youngest to oldest, all mid-point or mean ages of $95 \%$ probability ranges): Kaharoa AD $1314 \pm$ 12; Taupo (Unit Y) AD $232 \pm 10$; Mapara (Unit X) $2059 \pm 118$ cal. yr BP; Whakaipo (Unit V) $2800 \pm 60$ cal. yr BP; Waimihia (Unit S) $3401 \pm 108$ cal. yr BP, Stent (Unit Q) 4322 \pm 112 cal. yr BP; Unit K $5111 \pm 210$ cal. yr BP; Whakatane $5526 \pm 145$ cal. yr BP; Tuhua $6577 \pm 547$ cal. yr BP; Mamaku $7940 \pm 257$ cal. yr BP; Rotoma $9423 \pm 120$ cal. yr BP; Opepe (Unit E) $9991 \pm 160$ cal. yr BP; Poronui (Unit C) 11,170 \pm 115 cal. yr BP; Karapiti (Unit B) 11,460 \pm 172 cal. yr BP; Okupata 11,767 \pm 192 cal. yr BP; Konini (bed b) 11,880 \pm 183 cal. yr BP; Waiohau 14,009 \pm 155 cal. yr BP; Rotorua 15,635 \pm 412 cal. yr BP; 
Rerewhakaaitu 17,496 \pm 462 cal. yr BP; Okareka 21,858 \pm 290 cal. yr BP; Te Rere 25,171 \pm 964 cal. yr BP; Kawakawa/Oruanui 25,358 162 cal. yr BP; Poihipi 28,446 \pm 670 cal. yr BP; and Okaia $28,621 \pm 1428$ cal. yr BP.

Secondly, we have re-dated the start and end of the Lateglacial cool episode (climate event NZce-3 in the NZ-CES), previously referred to as the Lateglacial climate reversal, as defined at Kaipo bog in eastern North Island, New Zealand, using both Bacon and OxCal P_Sequence modelling with the IntCal09 data set. The ca. 1200-yr-long cool episode, indicated by a lithostratigraphic change in the Kaipo peat sequence to grey mud with lowered carbon content, and a high-resolution pollen-derived cooling signal, began 13,739 \pm 125 cal. yr BP and ended 12,550 \pm 140 cal. yr BP (mid-point ages of the $95 \%$ highest posterior density regions, Bacon modelling). The OxCal modelling, generating almost identical ages, confirmed these ages. The Lateglacial cool episode (ca. 13.8-12.6 cal. ka BP) thus overlaps a large part of the entire Antarctic cold reversal chronozone (ca. 14.1-12.4 cal. ka BP or ca. 14.6-12.8 cal. ka BP), and an early part of the Greenland Stadial-1 (Younger Dryas) chronozone (ca. 12.9-11.7 cal. ka BP). The timing of the Lateglacial cool episode at Kaipo is broadly consistent with the latitudinal patterns in the Antarctic cold reversal signal suggested for the New Zealand archipelago from marine and terrestrial records, and with records from southern South America.

\section{Keywords}

Tephras, tephrochronology, tephrostratigraphy, isochron, age modelling, Bayesian, Bacon, OxCal, radiocarbon, NZ-INTIMATE, Lateglacial cool episode, Lateglacial reversal, climate events, Termination 1, Kaipo bog, ACR, GS-1, YD, NZ-CES, NZce-3, marine reservoir, palaeoenvironmental reconstruction, volcanic eruptions, New Zealand, Patagonia 


\section{Introduction}

Tephrochronology is the use of tephra layers as isochrons to correlate and synchronize sequences in different places by providing precise chronostratigraphic tie-points, and to transfer numerical ages to such sequences where the tephras have been dated by radiometric, incremental, or other methods (Lowe, 2011). The role of tephrochronology as a linking and dating tool in palaeoenvironmental reconstructions, including INTIMATE projects (INTegration of Ice-core, MArine, and TErrestrial records) centred in both hemispheres, is well established (e.g. D.J. Lowe et al., 2008; J.J. Lowe et al., 2008; Moriwaki et al., 2011; Blockley et al., 2012; Davies et al., 2012). In New Zealand, the NZ-INTIMATE community developed an initial climate event stratigraphy based on identifying a series of well-dated, onshore and offshore proxy records from a variety of latitudes and elevations on a common calendar (cal.) timescale extending from 30,000 cal. yr BP to the present (Barrell et al., 2005; Alloway et al., 2007). A major advantage of these records (apart from those derived from speleothems) is that they are linked precisely by one or more tephra layers. Twenty-two tephras, derived from Taupo, Okataina, Tuhua, Tongariro, and Egmont/Taranaki volcanic centres (Fig. 1), were selected as marker beds for the NZ-INTIMATE project, and their stratigraphic relationships, distribution, composition, and ages were reported by D.J. Lowe et al. (2008). The ages were developed via Bayesian-based modelling using both OxCal and Bpeat programs, and utilised IntCal04 for tephras $<26,000$ cal. yr BP and 'comparison curves' for those $>26,000$ cal. yr BP. The 22 tephras were originally chosen in part because of their widespread distribution, each occurring $\sim 250 \mathrm{~km}$ or more from source. The close stratigraphic and temporal relationships of various tephra layers to signals of climatic or environmental change since 30,000 cal. yr BP were also documented (Alloway et al., 2007; D.J. Lowe et al., 2008). 
Fig. 1 about here

An important conclusion reached by the NZ-INTIMATE community is that no single climate record provides a definitive INTIMATE reference standard for the New Zealand region and, consequently, Alloway et al. (2007) used an array of proxy records from the New Zealand region to develop a composite stratigraphic framework of climatic events. The most recent initiative has been to formalise a New Zealand climate event stratigraphy (NZ-CES), tied to a composite inter-regional stratotype of three high-quality proxy records, that will facilitate enquiry into event regionality, and leads or lags in the timing of events (Barrell et al., in press). Clearly, it is essential that the chronology supporting the NZ-CES is as robust as possible, and also that the derivation and limitations of the chronological controls are well documented so that future modifications can be readily accommodated. Consequently, we tabulate here the age data underpinning the age calibrations and modelling of the marker tephras in detail.

In this paper, therefore, we have two main aims. Firstly, we revise the ages for the 22 marker tephras relevant to the NZ-CES by using the IntCal09 data set (Reimer et al., 2009), which extends to 50,000 cal. yr BP, using two Bayesian-based age-modelling programs, Bacon (Blaauw and Christen, 2011) and the P_Sequence function in OxCal4.1.7 (Bronk Ramsey, 2008, 2009a, 2009b) of the Kaipo bog tephra-peat sequence (following Hajdas et al., 2006). We also use the Bayesian Tau_Boundary function in OxCal4.1.7 to calibrate ages for both Holocene and pre-Holocene tephras (and ${ }^{14} \mathrm{C}$ wiggle-match dating of two late-Holocene tephras) using SHCal04 or IntCal09 data sets. Thus, 24 key tephras erupted in the past ca. 30,000 cal. years have now been dated. The use of such Bayesian-based modelling (and ${ }^{14} \mathrm{C}$ wiggle matching) techniques provides enhanced and more precise chronologies (e.g. Buck et al., 2003; Turney et al., 2003; Wohlfarth et al., 2006; Blockley et al., 2008, 2012; Olsen et al., 
2010). Ours is the first paper to apply these two different Bayesian flexible depositional modelling programs (Bacon, $P \_$Sequence) to develop the chronology of a long sequence. As well as providing new ages necessary for the NZ-CES (especially the Lateglacial transition) and other paleoenvironmental or archaeological applications, the tephra ages are also useful for volcanological, palaeoseismological, tectonic, and other studies in New Zealand (e.g. see Lowe, 2011).

Our second aim is to improve the accuracy and precision of the ages of onset and ending of the Lateglacial cool episode (Barrell et al., in press), previously referred to as the Lateglacial climate reversal, as recorded at Kaipo bog, an elevated, montane site in eastern North Island (Fig. 1), using Bacon and OxCal's $P \_S e q u e n c e$ function, and the IntCal09 data set. Such improvements are needed because the Kaipo sequence is a designated stratigraphic type record for the Lateglacial cool episode ('cool episode' hereafter), namely climate event NZce-3 in the NZ-CES, and the bracketing climate events NZce-4 and NZce-2 (Barrell et al., in press). In addition, the new ages obtained for the cool episode at Kaipo allow comparisons to be made with records from elsewhere in the New Zealand region, and enable their significance with respect to climatic change in the southern middle-latitudes - especially southern South America - during Termination 1 to be evaluated.

\subsection{The question of timing of the Lateglacial cool episode at Kaipo bog}

The onset of the cool episode, based on changes in pollen spectra and carbon content from high-resolution sampling, was dated in our initial study in 2000 at ca. 13,600 cal. yr BP, about 200 years after deposition of the Waiohau tephra, one of 16 visible tephras in the sequence; the ending was dated at ca. 12,600 cal. yr BP (Newnham and Lowe, 2000). That original Kaipo chronology comprised 14 tephrochronological and 20 conventional 
radiometric ages. To develop a finer-resolution age model, we added 20 new AMS-derived ${ }^{14} \mathrm{C}$ ages, giving 51 independently dated points in total. These 51 stratigraphically-ordered age-points were then modelled against IntCal04 (Reimer et al., 2004) using OxCal3 (Bronk Ramsey, 2001). The results, published in 2006, showed that Kaipo cooling began between 13,820-13,590 cal. yr BP and ended between 12,780-12,390 cal. yr BP (95\% probability ranges) (Hajdas et al., 2006), consistent with the findings of Newnham and Lowe (2000), even though they were based on relatively imprecise ages.

Subsequently, Lowe et al. (2007) used another Bayesian program, Bpeat (Blaauw and Christen, 2005), to re-date the cool episode at Kaipo. The Bpeat model (95\% probability ranges) showed that cooling began 13,472-13,351 cal. yr BP (13,450 cal. yr BP single-best iterative point-age estimate, known also as the maximum a posteriori estimator, MAP), somewhat later than the age range reported by Hajdas et al. (2006), and ceased 12,74812,416 cal. yr BP (MAP 12,645 cal. yr BP), similar to the age range estimated via OxCal3 by Hajdas et al. (2006) for the end of the cool episode.

Therefore, some uncertainty remained regarding the timing of the cool episode, especially the onset. That uncertainty related in part to considerable imprecision in the IntCal04 calibration curves around the Lateglacial period, and to assumptions regarding sedimentation rates. Moreover, the Bpeat analyses indicated that the age on Waiohau tephra, the key marker bed deposited several centuries before the onset of the cool episode at Kaipo (Newnham and Lowe, 2000), had a moderately high posterior outlier probability of $26.3 \%$, meaning that the chronology of this crucial interval was still open to question (D.J. Lowe et al., 2008). Thus, to allow valid comparisons of the timing of the cool episode at Kaipo bog with the timing of cooling events recorded at several other sites in New Zealand, including those from pollen-derived records (Turney et al., 2003; McGlone et al., 2004, 2010; Newnham et al., 2007b, 2012; Vandergoes et al., 2008), a chironomid-based temperature 
reconstruction (Vandergoes et al., 2008), speleothem-derived stable isotope records (Williams et al., 2005), and with glacier advances (Anderson and Mackintosh, 2006; Turney et al., 2007; Kaplan et al., 2010; Putnam et al., 2010; Barrell et al., 2011), we considered it essential to improve the ages on the cool episode signal at Kaipo (discussed also by Alloway et al., 2007; Newnham et al., 2012). The advent of IntCal09 has helped significantly to reduce the dating imprecision for this time period (Reimer et al., 2009), and the development of Bacon by Blaauw and Christen (2011), together with P_Sequence in OxCal (Bronk Ramsey 2008, 2009a, 2009b), provide modelling tools for us therefore to re-evaluate the chronology of Kaipo sequence, both for its constituent tephras and their relationship to climatic events, and for the timing of the cool episode, as reported below in sections 2 to 4 .

\section{Age models for 24 marker tephras erupted since 30,000 cal. yr BP}

The 24 tephras selected for the NZ-INTIMATE project, together with their source volcanoes and new ages, are summarised in Table 1. Note that numerous other tephras have been erupted from volcanoes in New Zealand in this time period (and earlier) - the 24 tephras selected are currently the most useful widespread marker beds for NZ-INTIMATE objectives. New work extending the known distribution of these tephras through cryptotephra studies is currently in progress (e.g. Gehrels et al., 2006, 2008; Holt et al., 2011). Of the 24 selected tephras, 22 are rhyolitic (silica-rich) and two are andesitic in composition: 12 of the rhyolitic tephras were derived from Taupo Volcanic Centre, nine were erupted from Okataina Volcanic Centre, and one peralkaline rhyolitic tephra was erupted from Tuhua Volcanic Centre (Mayor Island) (Fig. 1). One of the two andesitic tephras was derived from Egmont/Taranaki Volcano and the other from Tongariro Volcanic Centre (Fig. 1). Most of the tephras are widespread, the Kawakawa/Oruanui exceptionally so (Vandergoes et al., in 
press a), occupy a stratigraphic position that supports regional correlations, or are notably distinctive compositionally (e.g. Whakaipo and Tuhua tephras) (D.J. Lowe et al., 2008).

Five approaches have been used to develop the age models, reported as $95 \%$ probability age ranges, for the 24 tephras as indicated in Table 1, and these are described below in sections 2.1 to 2.5 .

Table 1 about here

\subsection{Wiggle-match dating of two late Holocene tephras using ${ }^{14} \mathrm{C}$ and tree-ring sequences}

Calendar dates on the two youngest tephras, Kaharoa and Taupo, were obtained (prior to our study) by wiggle matching log-derived tree-ring sequences dated by radiocarbon $\left({ }^{14} \mathrm{C}\right)$. Kaharoa tephra was dated $(2 \sigma)$ at AD $1314 \pm 12(636 \pm 12$ cal. yr BP mean age) by Hogg et al. (2003), the main plinian phases of the Kaharoa eruption occurring during the austral winter, approximately June-August (on the basis of tree-ring data). Taupo tephra (Unit Y) was dated $(2 \sigma)$ at AD $232 \pm 10(1718 \pm 10$ cal. yr BP mean age) by Hogg et al. (2012). Treering data and preserved plant macrofossils show that the eruption took place during the austral late summer to early autumn period, approximately March-April (Clarkson et al., 1988; Palmer et al., 1988). In comparison, ages derived independently for these eruptives by the flexible depositional modelling using Bacon (section 2.2 below) were $631 \pm 19$ cal. yr BP (mid-point age) and 633 cal. yr BP (weighted mean age, WMA) for Kaharoa, and $1699 \pm 51$ cal. yr BP (mid-point age) and 1710 cal. yr BP (WMA) for Taupo (Table 1). The WMA is a single-age representation that aims to take into account the general outcome of all Markov

Chain Monte Carlo (MCMC) iterations in the Bacon modelling (Blaauw and Christen, 2011; Blaauw and Heegaard, 2012). 


\subsection{Flexible depositional age-modelling of 16 Lateglacial to Holocene tephras at Kaipo peat}

sequence using Bacon and the IntCal09 data set

\subsubsection{Kaipo bog: origin, environment, and tephra-peat section}

Kaipo bog lies in a basin formed at the trailing edge of an extensive (ca. $\left.55 \mathrm{~km}^{2}\right)$ landslide complex of large-scale block slides (in which Lake Waikareiti has formed) in hilland mountain-country near Lake Waikaremoana in the Urewera ranges of Te Urewera National Park, eastern North Island (Fig. 1; Ward, 1995; Lowe et al., 1999; Beetham et al., 2002; Leonard et al., 2010). Sediment derived from the surrounding debris and bedrock slopes, which are composed of sandstone and soft, blue-grey siltstone or mudstone (Moore, 1979; Leonard et al., 2010), appears to have substantially infilled the Kaipo basin before peat bog development began ca. 18,000 cal. yr BP (Lowe et al., 1999). With an area of 73 ha, Kaipo bog is an ombrogenous shrub bog dominated by rushes (mainly Empodisma minus) and ferns (Gleichenia dicarpa), with occasional Sphagnum spp., which form low hummocks amongst numerous small, permanent pools (Fig. 2) (Lowe et al., 1999). Beyond a narrow marginal zone of scrub-forest at its edges, the bog is surrounded largely by montanesubalpine beech forest (mainly Nothofagus menziesi and N. fusca) and shrubland (McKelvey, 1973). It lies at an elevation of ca. $980 \mathrm{~m}$ with contemporary treeline ca. $400 \mathrm{~m}$ higher (Newnham and Lowe, 2000). Mean summer temperature at Kaipo is ca. $13.2^{\circ} \mathrm{C}$, mean winter temperature is ca. $4.2^{\circ} \mathrm{C}$, and mean annual precipitation is ca. $2688 \mathrm{~mm}$ (after data in Leathwick et al., 2002, 2003).

At the southwestern end of the bog, where a salient of beech forest protrudes into it (Fig. 2), surface drainage, together with headward erosion, have incised and eroded the peat deposits to expose a series of low scarps comprising a ca. 4.4-m high sequence of peats and 
inorganic muds containing 16 visible tephra layers spanning Lateglacial and Holocene time (Fig. 3) (Lowe et al., 1999; see Fig.7 in Alloway et al., 2007, p. 20). Although the full sequence is difficult to see in any one section because of differing watertable levels, and because fallen trees and debris covered with forest undergrowth limit access, the physical properties of the tephra layers and other lithological features, together with stratigraphic relationships, allow the adjacent sections (only ca. 5-10 m apart) to be readily linked to one another (Lowe et al., 1999).

Fig. 2 about here

Fig. 3 about here

\subsubsection{Flexible depositional age-modelling of 16 tephras at Kaipo using Bacon}

We obtained new calendar ages on each tephra using Bacon (Blaauw and Christen, 2011) and IntCal09 (Reimer et al., 2009) after first subtracting $44 \pm 17$ years from the ${ }^{14} \mathrm{C}$ ages in the modelling to correct for the Southern Hemisphere offset (Hogg et al., 2011; Supplementary materials Table S1). These new ages in Table 1 are reported as mid-points of the extremes of the $95 \%$ confidence intervals, i.e. the mid-points of the highest posterior density (HPD) regions. An HPD region is the shortest possible range of parameter values within which all values are more likely than those outside (Buck et al., 2003; Blaauw and Heegaard, 2012). Typically, such regions are computed so that they contain a fixed percentage of the posterior probability, often (as applied here) so that all age intervals reported are the shortest needed to contain $95 \%$ of the posterior distribution. The $95 \%$ HPD region is not necessarily continuous (i.e. it can be multi-modal) (Buck et al., 2003). Bacon uses a gamma autoregressive semiparametric model with an arbitrary number of subdivisions through the sediment. Outliers were addressed using a new Student- $t$ model for radiocarbon 
data (Christen and Pérez, 2009; Blaauw and Heegaard, 2012). The posterior ages derived from Bacon depend to a degree on the prior assumptions provided. For example, prior information regarding variability in accumulation rate can be set in Bacon by changing the 'memory' (the mean and shape of a beta distribution). We used the default settings for Bacon's memory (Blaauw and Christen, 2011).

In the previous age modelling at Kaipo, we had used $40{ }^{14} \mathrm{C}$ ages obtained from the Kaipo sequence (effectively 37 ages because three pairs of ages on three samples were combined; see Fig. 3) together with ${ }^{14} \mathrm{C}$ ages on 14 of the 16 tephra layers (Hajdas et al., 2006; D.J. Lowe et al., 2008). Here we have added the two youngest tephra layers, Kaharoa (AD $1314 \pm 5,1 \sigma$-range) at $13 \mathrm{~cm}$ depth, and Taupo (AD $232 \pm 5,1 \sigma$-range) at $18 \mathrm{~cm}$ depth, to the depositional age-modelling sequence (Fig. 3, Table S1). These two tephras provide very precise and well-dated stratigraphic points and so ages on all 16 identified tephra layers at Kaipo now underpin the modelling. The total of 53 stratigraphically-ordered, independent age-points (i.e. 37 local ${ }^{14} \mathrm{C}$ ages, 16 tephrochronological ages) used in the age modelling represents one point per ca. 330 calendar years on average (Table S1).

We additionally revised the pooled mean ${ }^{14} \mathrm{C}$ ages associated with six of the tephras in the Kaipo sequence, namely Rerewhakaaitu, Rotorua, Waiohau, Konini, Opepe, and Tuhua, using OxCal-based Tau_Boundary combining procedures as described in sections 2.4 and 2.5 below, before undertaking the Bacon and $P \_$Sequence modelling. This revision, in part, of the fundamental Kaipo age-depth sequence (Fig. 3) was undertaken for three reasons. Firstly, we wanted to enhance the age modelling pertaining especially to the Lateglacial transition which includes the New Zealand Lateglacial cool episode. Secondly, our previous age-depth modelling at Kaipo using Bpeat had indicated that the mean ${ }^{14} \mathrm{C}$ ages on three tephras had outlier probabilities that exceeded $15 \%$ : Waiohau (outlier probability $26.3 \%$ ), Konini (16.6\%), and Opepe (100\%) (D.J. Lowe et al., 2008). Therefore we re-evaluated all ${ }^{14} \mathrm{C}$ ages 
used to derive the pooled mean ages attributed previously to each of these tephras. Thirdly, our preliminary age modelling using Bacon identified a large error associated with the age of Tuhua tephra ( \pm ca. 500 years). Consequently, we re-evaluated the original ${ }^{14} \mathrm{C}$ ages used to derive the mean age for this tephra as well. The revised mean calibrated ages $( \pm 1 \sigma)$ on all six tephras are listed in Fig. 3. The mean ages on five of them differ by only 100-200 years from those used by Hajdas et al. (2006) and D.J. Lowe et al. (2008), but the age on Waiohau tephra is substantially older by about $600{ }^{14} \mathrm{C}$ years (discussed further below).

Finally, to optimise the age-modelling process, we split the Kaipo age-depth data set (Table S1) arbitrarily into two segments, upper (0 to $50 \mathrm{~cm}$ depth, tephra-free basis) and lower (50 to $281 \mathrm{~cm}$ depth, tephra-free basis). There is a marked change in average sedimentation rates at around this point, the upper segment reflecting very slow rates of ca. $0.07 \mathrm{~mm} / \mathrm{yr}$ on average whereas faster rates, between ca. 0.17 and $0.52 \mathrm{~mm} / \mathrm{yr}$, characterize the lower segment (Lowe et al., 1999; Newnham and Lowe, 2001). The Bacon-derived posterior age-depth models (in grey) for these upper and lower segments are given in Figs. 4 and 5, respectively. The calibrated distributions of the individual dates are shown in blue or green $\left({ }^{14} \mathrm{C}\right.$ or cal. yr BP, respectively, in Fig. 3), and the grey dots indicate the models' $95 \%$ probability intervals. The three insets at the top of each graph show (i) the number of MCMC iterations used to generate the grey-scale graphs (top left), (ii) the prior (green) and posterior (grey) distributions of accumulation rates (top centre), and (iii) memory R (top right) for the Kaipo sequence (see Blaauw and Christen, 2011).

Fig. 4 about here

Fig. 5 about here 
The Bacon-derived age models for all 16 tephras in the Kaipo sequence are depicted as histograms in Fig. 6 (upper segment) and Fig. 7 (lower segment).

Fig. 6 about here

Fig. 7 about here

The new calendar ages derived via Bacon for the 16 tephras at Kaipo (Table 1) are generally indistinguishable, within ca. 100 to 150 cal. years at face value, from those obtained previously by D.J. Lowe et al. (2008). At face value, three tephras, however, are ca. 200-400 cal. years older, namely Waiohau, Konini, and Okupata, whereas Tuhua tephra is ca. 400 cal. years younger than the age derived from the earlier modelling, but with a notably large $2 \sigma-$ error of ca. 550 cal. years. There are several possible reasons why the Bacon-derived age on the Tuhua tephra is so imprecise in comparison with the precision attained for the other Holocene tephras. One possibility is that differential deposition or erosion of bog sediments has confounded the modelling. For example, a 3-cm-thick layer of inorganic grey mud lies immediately beneath Tuhua tephra (Fig. 3). Such mud has not been observed in any other part of the Holocene peat sequence at Kaipo: in an earlier study at a nearby section, Lowe and Hogg (1986) found neither Tuhua nor Mamaku tephras, and hence Lowe et al. (1999) suggested that these tephras had been eroded from that part of the sequence. Thus, local erosion of the peat may have occurred at around the time of deposition of Tuhua tephra in the sequence currently under study. Secondly, we comment that in developing the posterior agedepth model, Bacon effectively reflects a trade-off between using dates on the one hand, and using prior information about accumulation rate and variability on the other. Given that Bacon addresses outliers using a Student- $t$-based model, the dates have longer probability tails than if the usual Gaussian distributions were used. In the case here for Tuhua tephra, the 
models have to fit through the ages around $8000 \mathrm{cal}$. yr BP (at 44 and $45 \mathrm{~cm}$ depths, tephrafree basis) and around $5300 \mathrm{cal}$. yr BP (at 38 and $39 \mathrm{~cm}$ depths, tephra-free basis), and then 'bend' to reach the dates around 35 and $36 \mathrm{~cm}$ depths. In order to do so while obeying the accumulation rate variability (set at 'very variable', 'low memory' in Bacon), the models cannot concomitantly go straight through the Tuhua tephra age point. The result is a wide uncertainty range and ages that do not agree well with the original age on Tuhua (of Table S1). As a sensitivity test, we artificially increased the precision of Tuhua tephra to just 1 year, and removed the Student- $t$ distribution just for that date (none of the other ones). The result was, unsurprisingly, that the age-models ran closer to the Tuhua date (graphical output not shown). But obviously we cannot assume that sort of precision for this flexible depositional age modelling. Acquiring more dates from the sequence around the time of eruption of Tuhua tephra (i.e. in the zone between ca. 6000 and 8000 cal. years ago) would help to resolve the uncertainty.

\subsection{Flexible depositional age-modelling of 16 Lateglacial to Holocene tephras at Kaipo peat} sequence using P_Sequence function in OxCal4.1.7 and the IntCal09 data set

As a check on the Bacon-derived ages for the tephras at Kaipo, we obtained calendar ages on each tephra using the Bayesian $P_{-}$Sequence function in OxCal4.1.7 (Bronk Ramsey, 2008, 2009a, 2009b) and IntCal09 (Reimer et al., 2009) after initially correcting for the Southern Hemisphere offset (Table S1). The new P_Sequence-derived mean ages are given in Table 1. As for Bacon, the posterior ages derived from OxCal's $P_{-}$Sequence depend to a degree on the prior assumptions provided. For example, prior information regarding variability in accumulation rate, assumed to be a Poisson process (Bronk Ramsey, 2008), can be set by changing OxCal's ' $\mathrm{k}$ ' parameter in the $P_{-}$Sequence function (the larger the k 
parameter, the more rigid the model). We set $\mathrm{k}$ to 10 for the upper segment $(0-50 \mathrm{~cm}$ depth, tephra-free basis) (Supplementary material Fig. S1), and to 2 for the lower one (50 to $281 \mathrm{~cm}$ depth) (Supplementary material Fig. S2). Setting k to 5 or 10 for the lower segment resulted in a model that seemed overly rigid.

We comment on three features evident in the resultant $P \_$Sequence-derived ages on the 16 tephras. Firstly, apart from those on Rerewhakaaitu and Tuhua tephras, the mean ages at face value are very similar to the mid-point ages derived using Bacon, 12 being within 55 years and two within 95 years. Secondly, at face value, the $P \_$Sequence age on Rerewhakaaitu tephra $(17,209 \pm 249$ cal. yr BP $)$ is nearly 300 years younger than the Baconderived age $(17,496 \pm 462$ cal. yr BP $)$ and ca. 600 years younger than the Tau_Boundary age $(17,845 \pm 380$ cal. yr BP $)$; and the $P \_S e q u e n c e$ age on Tuhua tephra $(6947 \pm 150$ cal. yr BP $)$ is ca. 370 years older than the Bacon age $(6577 \pm 547$ cal. yr BP) but similar to the Tau_Boundary age $(7027 \pm 170$ cal. yr BP) (Table 1$)$. The uncertainty regarding the Bacon modelling for Tuhua tephra was discussed earlier - possibly with the settings as applied the $P \_$Sequence modelling gives greater weight to the dates at the 'cost' of age-model variability/constancy. Thirdly, the $2 \sigma$-errors on the $P \_S e q u e n c e$-derived mean ages for all tephras are smaller by $\sim 25-70 \%$ than those associated with the Bacon mid-point ages.

We adopt here the more conservative Bacon-derived ages but record that in most cases they differ little from the 95\%-age ranges derived separately using the OxCal-derived $P \_$Sequence ages, lending confidence to our new chronologies developed for the tephras at Kaipo bog.

2.4. Calibrating ages of six Holocene tephras using Tau_Boundary function in OxCal4.1.7 with SHCal04 and IntCal09 data sets 
The new ages we obtained for the five eruptions of Mapara (Unit X), Whakaipo (Unit V), Stent (Unit Q), Tuhua, and Opepe (Unit E) tephras, reported in Table 2, were calibrated using the SHCal04 data set (McCormac et al., 2002, 2004) with inbuilt interhemispheric offset correction. The new age for the eruption of bed $b$, the younger of two beds that define the Konini tephra (Alloway et al., 1995), was calibrated using the IntCal09 data set (Reimer et al., 2009) after initially correcting for the Southern Hemisphere offset (Table 2).

Radiocarbon ages pertaining to each of the six Holocene tephras were divided into three stratigraphic groups: pre-eruption, syn-eruption, and post-eruption. We then generated modelled maximum probability ages for the eruption group boundaries using the Bayesian Tau_Boundary function within OxCal4.1.7 (Bronk Ramsey, 2009b). Outliers were identified and removed from the final modelling that then generated calibrated age ranges and mean ages (95.4\% probability) for the eruption of each tephra (Table 2).

Table 2 about here

The new calendar ages derived are generally consistent with ages obtained in several recent studies including those of Briggs et al. (2006), Gehrels et al. (2006), and Page et al. (2010). The preferred age for Whakaipo tephra in D.J. Lowe et al. (2008) was $2960 \pm 190$ cal. yr BP. The new age we have derived here for Whakaipo tephra is $2800 \pm 60 \mathrm{cal}$ yr. BP (Table 2). The OxCal Tau_Boundary-derived age on Tuhua tephra $(7027 \pm 170 \mathrm{cal}$. yr BP) is somewhat at odds with that derived using Bacon modelling (6577 $\pm 547 \mathrm{cal}$. yr BP), as discussed above, but agrees better with the age derived using OxCal's $P$ _Sequence modelling $(6947 \pm 150$ cal. yr BP) (Table 1). 


\subsection{Calibrating ages of eight pre-Holocene tephras using using Tau_Boundary function in OxCal4.1.7 and the IntCal09 data set}

The new ages relevant to the eruptions of Waiohau, Rotorua, Rerewhakaaitu, Okareka, Te Rere, Kawakawa/Oruani, Poihipi, and Okaia tephras, reported in Table 3, were calibrated using the IntCal09 data set (Reimer et al., 2009) after correcting for the Southern Hemisphere offset (Table 3). The radiocarbon ages pertaining to each of the eight tephras were divided, as in Section 2.4, into three stratigraphic groups: pre-eruption, syn-eruption, and post-eruption. Using OxCal4.1.7 (Bronk Ramsey, 2008, 2009b), we generated modelled maximum probability ages for the eruption group boundaries using the Tau_Boundary function. Outliers were identified and removed from the final modelling that then generated calibrated age ranges and mean ages (95.4\% probability) for the eruption of each tephra (Table 3).

Table 3 about here

Of the five oldest tephras (Okaia, Poihipi, Kawakawa/Oruanui, Te Rere, and Okareka), the $2 \sigma$-errors on Okaia (1428 cal. yrs), Poihipi (670 cal. yrs), and Te Rere (964 cal. yrs) are notably high. Such errors indicate that these tephras remain very poorly dated in comparison with Kawakawa/Oruanui and Okareka. Because field evidence indicates significant periods of loess deposition and soil formation, and/or erosion, between the Kawakawa/Oruanui and Te Rere tephras, and between Okaia and Poihipi tephras (e.g. Vucetich and Pullar, 1969; Vucetich and Howorth, 1976; Benny et al., 1988; Lanigan, 2012; Lowe et al., 2012), then optimum carbonaceous material should be sought for new ${ }^{14} \mathrm{C}$ dating and modelling to refine these ages (as undertaken for the Kawakawa/Oruanui tephra by Vandergoes et al., in press a). 
Potential alternative tephra dating methods were discussed by D.J. Lowe et al. (2008) (see also Danišík et al., 2012).

The calibrated ages obtained for Poihipi, Te Rere, and Okareka tephras are similar to those obtained by D.J. Lowe et al. (2008); that on Okaia tephra, however, is ca. 1300 cal. years younger at face value (but with a large error of comparable magnitude). The calibrated age obtained for Kawakawa/Oruanui, ca. 25,360 cal. yr BP, is considerably younger (by ca. 1700 cal. years at face value) than the age endorsed by D.J. Lowe et al. (2008, 2010), derived from dating four carbonized branch or twig fragments from within Oruanui ignimbrite by Wilson et al. (1988). The new age is based on the dating of newly acquired, optimal sample materials (Vandergoes et al., in press a), and has much smaller errors than the previous age, partly because the new age was derived by Bayesian modelling (using Tau_Boundary) incorporating eight syn-eruption ages defining the eruption closely as well as another 14 ages on plant material deposited just before and just after the eruption (Table 3). Similarly, the new age on Okareka tephra has a smaller error, about half that reported by D.J. Lowe et al. (2008), chiefly because new dates became available that enabled us to utilise the OxCalbased modelling.

The three youngest tephras in this set (Rerewhakaaitu, Rotorua, and Waiohau) have now been dated using the Bacon and $P \_$Sequence age modelling, described already, and OxCal's Tau_Boundary modelling, with interesting results (Table 3). For Rerewhakaaitu tephra, the Bacon-derived age (at face value) is ca. 300 years older than that derived using P_Sequence; the age derived using Tau_Boundary modelling is older by ca. 300 and ca. 600 years than the Bacon and $P \_S e q u e n c e$ ages, respectively. For Rotorua tephra, the ages are effectively the same for all three approaches. For Waiohau tephra, the Bacon and P_Sequence-derived ages are identical whereas that derived using Tau_Boundary is ca. 300 years older. We adopt here the Bacon-derived ages, well supported by the $P_{-}$Sequence- 
derived ages that are similar for these three tephras. The Bacon-derived ages on Rerewhakaaitu and Rotorua tephras in Table 1 are similar to those obtained earlier by D.J. Lowe et al. (2008), but Waiohau tephra is now shown to be aged ca. 14,000 cal. yr BP using both the Bacon and $P \_S e q u e n c e$ age modelling, considerably older than previously estimated (ca. 13,650 cal. yr BP) by D.J. Lowe et al. (2008).

Several questions have therefore been resolved about the earlier age modelling undertaken with $\mathrm{OxCal}$ and Bpeat with regard to the age of the Waiohau tephra and adjacent ${ }^{14} \mathrm{C}$ ages, as discussed by D.J. Lowe et al. (2008, pp. 109-110). This older eruption age for Waiohau tephra is important, firstly, because it was deposited only a few centuries before the start of the cool episode (see Section 3 below). Secondly, the new date essentially removes the outlier in the paper by Sikes et al. (2000) on surface marine radiocarbon reservoir offsets at this time (Section 3). Note that high-resolution pollen analysis of samples from immediately above Waiohau tephra recorded an impact arising from the tephra deposition that persisted for a few decades to perhaps a century (marked lithologically by landscape instability and the initial deposition of pale brownish-grey mud in the sequence; Fig. 3). But subsequent samples showed a full recovery of the forest cover within about two centuries and stabilisation of the landscape (marked by the deposition of dark brown peaty mud, referred to as peaty mud layer A in Fig. 3) (Newnham and Lowe, 2000).

\section{Stratigraphic proximity of tephra marker beds to key climatic changes}

Although all the newly-dated tephras are useful chronostratigraphic markers in palaeoenvironmental reconstructions in New Zealand, some of the tephras are particularly important because their deposition coincided closely with boundaries between climatic events identified in the NZ-CES framework. D.J. Lowe et al. (2008) described the chronological 
relationships between such marker tephras and seven inferred climatic events established from $\delta^{18} \mathrm{O}$ and $\delta^{13} \mathrm{C}$ records from composite speleothem data published by Williams et al. (2004, 2005), and chronostratigraphically with the preliminary NZ-CES framework of Alloway et al. (2007). Because the tephras that approximate the positions of boundaries between climatic events defined in the NZ-CES composite stratotype are described by Barrell et al. (in press), only a summary is given here, along with isopach maps showing the distributions of three of these stratigraphically important tephras.

Although Poihipi tephra (ca. 28.5 cal. kilo years [ka] BP) has quite a large age uncertainty, it broadly approximates the boundary of climatic events NZce-11 and NZce-10, representing the onset of full glacial climatic conditions at ca. 28.8 cal. ka BP (Barrell et al., in press; see also Vandergoes et al., in press b). Glaciological simulation of 'maximum' Last Glacial Maximum (LGM) ice extent - with $6-6.5^{\circ} \mathrm{C}$ cooling and a precipitation regime about $25 \%$ drier than today's - by Golledge et al. (2012) probably coincides largely with glacier advances during event NZce-10 for which strong cooling is inferred from pollen and palaeolimnological biomarkers (Newnham et al., 2007b, in press; Zink et al., 2010), and from sea-surface temperatures estimated to be as much as $7^{\circ} \mathrm{C}$ cooler than today's on the basis of marine microfossil assemblages (Bostock et al., in press).

The Kawakawa/Oruanui tephra (ca. 25.4 cal. ka BP) lies at the boundary between climatic events NZce-10 and NZce-9, representing the onset of an interstadial within the Last Glacial Coldest Period, LGCP (also referred to as the 'extended' Last Glacial Maximum, eLGM, by Newnham et al., 2007a; see also Suggate and Almond, 2005; Augustinus et al., 2011; Lorrey et al., 2012). The very wide distribution of Kawakawa/Oruanui tephra is shown by isopach maps (Carter et al., 1995; Wilson, 2001; Alloway et al., 2007; D.J. Lowe et al., 2008; Vandergoes et al., in press a). As well as being a critically important isochron for the NZ-CES, the new age for Kawakawa/Oruanui tephra additionally allows marine reservoir 
ages to be revised for the LGM (Vandergoes et al., in press a). Based on age data reported on planktonic and benthic foraminifera for this tephra by Sikes et al. (2000), the surface marine reservoir age broadly in the New Zealand region is now $3280 \pm 190{ }^{14} \mathrm{C}$ yrs (cf. previously $1990 \pm 270{ }^{14} \mathrm{C}$ yrs) and the apparent ventilation age is $4760 \pm 190{ }^{14} \mathrm{C}$ yrs (cf. previously $3470 \pm 270{ }^{14} \mathrm{C}$ yrs) (Vandergoes et al., in press a).

The Okareka tephra (ca. 21.9 cal. ka BP) approximately coincides in time with the boundary between a brief interstadial (NZce-7) and the last major stadial of the LGM (NZce$6)$.

The Rerewhakaaitu tephra (ca. 17.5 cal. ka BP) is widespread in North Island and offshore (Fig. 8), and coincides approximately with the onset of climatic amelioration (NZce5) following Termination 1, the end of the final major stadial of the eLGM (NZce-6). The importance of this tephra as an approximate stratigraphic marker for Termination 1 in both terrestrial and marine records was documented by Newnham et al. (2003) and others (e.g. Samson et al., 2005; Litchfield and Berryman, 2005, 2006; Newnham et al., 2012).

Fig. 8 about here

The Rotorua tephra (ca. 15.6 cal. ka BP) marks the boundary between NZce-5 (postTermination amelioration) and NZce-4 (Lateglacial mild episode) in both Pukaki and Kaipo sequences (Barrell et al., in press).

The Waiohau tephra (ca. 14.0 cal. ka BP), widespread in North Island and offshore to the east (Fig. 9), marks approximately the boundary between NZce-4 (Lateglacial mild episode) and NZce-3 (Lateglacial cool episode). It occurs just before the onset of the cool episode (Fig. 7). As noted previously, the new terrestrial age derived for Waiohau tephra has allowed us to re-evaluate the surface marine radiocarbon reservoir offset for the Lateglacial 
period. Sikes et al. (2000) estimated the offset at the time of the Waiohau tephra eruption to be ca. $800{ }^{14} \mathrm{C}$ years, and Carter et al. (2008) utilised an offset of $776{ }^{14} \mathrm{C}$ years. Our new age on Waiohau tephra reduces the offset closer to the global average marine reservoir age of approximately $400{ }^{14} \mathrm{C}$ years (Ascough et al., 2005; cf. Austin et al., 1995; Bondevik et al., 2006; Ohkushi et al., 2007; Ikehara et al., 2011; Thornalley et al., 2011). Deriving a precise error-weighted mean terrestrial radiocarbon age for the Waiohau eruption is problematic because of considerable age variability in the data set (which is why we adopted the Bayesian modelling approach to ascertain its calendar age). The mean radiocarbon age of the samples used for the Tau_Boundary modelling in Table 3 (excluding Wk531) is $12,417 \pm 279{ }^{14} \mathrm{C}$ yr BP ( $n=12 ; \chi^{2}$-test statistics: d.f. $11, T=24.5$ [5\% 19.7]). Although the samples do not quite pool at the $95 \%$ confidence level, comparison of this mean age with age data reported on planktonic and benthic foraminfera for Waiohau tephra by Sikes et al. (2000) indicates that the surface marine reservoir age in the New Zealand region at this time is about $230 \pm 290$ ${ }^{14} \mathrm{C}$ yrs (cf. $800 \pm 110{ }^{14} \mathrm{C}$ yrs), and the apparent ventilation age is $1080 \pm 290{ }^{14} \mathrm{C}$ yrs (cf. $1650 \pm 80{ }^{14} \mathrm{C}$ yrs). Although imprecise, the new surface marine reservoir age for the Lateglacial in New Zealand nevertheless appears to be substantially less than 800 years.

Fig. 9 about here

The Konini tephra (bed b) (ca. 11.9 cal. ka BP) is the designated benchmark for the Pleistocene-Holocene boundary for the Australasian parastratotype at Lake Maratoto near Hamilton in northern North Island (Fig. 10; Walker et al., 2009). This tephra also marks the boundary between NZce-2 (pre-Holocene amelioration) and NZce-1 (undifferentiated Holocene interglaciation) in the NZ-CES type section at Kaipo bog (Barrell et al., in press). Although an andesitic eruptive from Egmont/Taranaki volcano of limited volume, the Konini 
tephra is nonetheless reasonably widespread over considerable parts of North Island, being recorded as a very thin visible layer in deposits on both the western and eastern sides of the island, and in the Waikato and Auckland regions (Fig. 10). It is likely to occur beyond these known limits as a cryptotephra. Konini tephra (bed b) occurs commonly in close stratigraphic proximity to an overlying andesitic tephra from Tongariro Volcanic Centre, Okupata tephra (ca. 11.8 cal. ka BP; see also Pardo et al., 2012), and this occurrence in the field as a couplet (Fig. 7) is often a ready means of identification despite both tephras being very thin in distal localities.

Fig. 10 about here

Within the Holocene, numerous tephras are locally useful chronostratigraphic markers, as noted by D.J. Lowe et al. (2008). The Rotoma (ca. 9.4 cal. ka BP) and Mamaku tephras (ca. 7.9 cal. ka BP) together encapsulate the time interval that includes the North Atlantic ca. 8.2 cal. ka BP cold event (e.g. Alley et al., 2007; Augustinus et al., 2008; Nicolussi and Schlüchter, 2012) as well as the early Holocene-middle Holocene boundary proposed by Walker et al. (2012). Mamaku tephra also approximates the younger age limit of the NZINTIMATE project. The Tuhua tephra (ca. $6.6 \mathrm{cal}$. ka BP) was erupted possibly several centuries after the attainment of present-day sea level at ca. 7.2 cal. ka BP (Carter et al., 2000; D.J. Lowe et al., 2008).

The Stent tephra (Unit Q) (ca. 4.3 cal. ka BP) is close to the age of the ca. 4.2 cal. ka BP aridification event (e.g. de Menocal et al., 2001; Booth et al., 2005; Menounos et al., 2008) (not yet observed in New Zealand), which marks the postulated middle-to-late Holocene boundary (Walker et al., 2012). The Taupo tephra (Unit Y) (ca. AD 232) provides a widespread benchmark prior to Polynesian settlement in North Island (Hogg et al., 2012), 
whereas the Kaharoa tephra (ca. AD 1314) provides an early Polynesian settlement datum in eastern and northern North Island (Newnham et al., 1998; Hogg et al., 2003; Lowe, 2011).

\title{
4. Timing of the Lateglacial cool episode at Kaipo bog and palaeoclimatic implications
}

\author{
4.1. New ages for the onset and ending of the cool episode derived using Bacon and \\ P_Sequence function in OxCal4.1.7 and the IntCal09 data set
}

The grey muds that mark the definitive signal of the Lateglacial cool episode at the Kaipo bog section derived presumably from the erosion of surrounding landslide debris and bedrock slopes. The cooling signal was obtained from the high-resolution pollen analysis of more than 60 contiguous samples taken at ca. 5-millimetre intervals (representing 1 sample per 24 years on average) from the pale grey mud unit that extends stratigraphically from just above the Waiohau tephra at $3.48 \mathrm{~m}$ depth to the dark brown peat at $2.96 \mathrm{~m}$ depth (these depths are inclusive of tephra layers, Fig. 3) (Newnham and Lowe, 2000). In addition, around $20{ }^{14} \mathrm{C}$ dates were obtained from (bulk) sediments in this specific time interval (approximately one date per ca. 70 years on average) (Fig. 3) and so the chronology is likely to be very robust. The dark-brown peaty mud layer A, representing recovery of landscape stability and forest cover after the impacts of the deposition of Waiohau tephra (Newnham and Lowe, 2000), is dated here using the Bacon age-depositional modelling at between $13,820 \pm 113$ cal. yr BP (lower part of peaty mud layer A at 231-cm depth, tephra-free basis) and 13,787 \pm 125 cal. yr BP (upper part of peaty mud layer A at 230-cm depth, tephra-free basis). (These ages, and others reported below from Bacon modelling, are all mid-points of the $95 \%$ HPD probability intervals defined earlier.) 
From the Bacon modelling, the sample $1 \mathrm{~cm}$ above the peaty mud layer A $(229-\mathrm{cm}$ depth, tephra-free basis) has an age of 13,765 \pm 123 cal. yr BP. The sample immediately stratigraphically above it at 228-cm depth (tephra-free basis) palynologically marks the onset of the cool episode NZce-3 (Newnham and Lowe, 2000); it has an age of 13,739 \pm 125 cal. yr BP (Fig. 11). The sample at 182-cm depth (tephra-free basis) at the top of the grey mud palynologically marks the ending of the cool episode NZce-3 (Newnham and Lowe, 2000); it has an age of 12,550 \pm 140 cal. yr BP (Fig. 11). In comparison, the $P \_S e q u e n c e$ modelling (lower sequence at Kaipo, $\mathrm{k}=2$ ) gave a mean age for the onset of cooling (marked by the sample at 228-cm depth) of 13,732 $\pm 76 \mathrm{cal}$. yr BP, and a mean age for the end of cooling (marked by the sample at $182-\mathrm{cm}$ depth) of $12,575 \pm 57$ cal. yr BP. These $P \_$Sequencederived ages are essentially identical to those obtained using Bacon, but with higher precision ( $2 \sigma$-errors are about half those from Bacon modelling). This very close concordance of the results from the two different age-modelling programs gives us confidence therefore that the ages for NZce-3 are likely to be accurate. For consistency, we adopt the more conservative Bacon-derived ages, which are discussed further below.

Fig. 11 about here

It is thus evident that the cool episode (NZce-3) persisted for ca. 1200 cal. years at Kaipo bog. The onset at ca. 13,739 \pm 125 cal. yr BP is earlier than that advocated by Lowe et al. (2007) but comparable to the age of onset reported by Hajdas et al. (2006) and Newnham and Lowe (2000). The onset and the ending of the cool episode are both dated with better precision (125-140 years from Bacon modelling) than previously. These new age boundaries for climate event NZce-3 additionally demark in part the boundaries of climate events NZce- 
4 (ca. 15.6-13.8 cal. ka BP) and NZce-2 (ca. 12.6-11.9 cal. ka BP), which are also defined at the Kaipo bog stratotype (see Barrell et al., in press).

We note here that the pale grey muds representing the cooling episode are briefly 'interrupted' by a ca. 5- to 6-cm-thick layer of dark brown peaty mud (denoted peaty mud layer B in Fig. 3). The Bacon age modelling indicates that the base of layer B, at $214 \mathrm{~cm}$ depth (tephra-free basis), is ca. 13,497 \pm 115 cal. yr BP; the top of layer B, at approximately 208-cm depth (tephra-free basis), is ca. 13,370 1132 cal. yr BP. Currently, the significance, if any, of this relatively subtle lithological change, representing an interval of ca. 125 years, is not known, but is the subject of further investigation.

\subsection{Palaeoclimatic implications and discussion}

The ca. 1200-yr-long cool episode defined at Kaipo bog from ca. 13.8 to $12.6 \mathrm{cal}$. ka BP overlaps most of the Antarctic cold reversal (ACR) chronozone, which has an age range estimated between ca. 14.1 and 12.4 cal. ka BP (following Calvo et al., 2007; Carter et al., 2008; Bostock et al., in press; Fig. 11), although García et al. (2012), following LemieuxDudon et al. (2010), proposed an age range from ca. 14.6 to 12.8 cal. ka BP, matching that of Putnam et al. (2010). The cool episode also overlaps the first part of Greenland Stadial 1 (GS1), or Younger Dryas (YD), which has an age range estimated between ca. 12.9 and 11.7 cal. ka BP (Blockley et al., 2012) (Fig. 11). The significance of the Lateglacial cool episode in New Zealand has been discussed at length in a number of papers, as noted in the introduction, and also by Barrell et al. (in press), but there is a growing corpus of evidence for glacier advances in the Southern Alps that culminated at ca. 13.0 cal. ka BP (Applegate et al., 2008; Putnam et al., 2010; Kaplan et al., 2010; Kirkbride and Winkler, 2012), with associated quantification of atmospheric temperature conditions from biological proxies (Vandergoes et 
al., 2008) as well as glaciological proxies (i.e. temperatures were depressed by ca. $2-3{ }^{\circ} \mathrm{C}$ ) (Doughty et al., in press), coinciding indistinguishly in time with the Antarctic atmospheric temperature minimum of the ACR (Lemieux-Dudon et al., 2010; García et al., 2012). Putnam et al. (2010) concluded that the extensive cooling associated with the ACR was caused by northward migration of the southern Subtropical Front, and concomitant northward expansion of cold waters of the Southern Ocean. The coldest part of the cool episode at Boundary Stream tarn in the central Southern Alps occurred between ca. 13.9 and 13.2 cal. ka BP (Vandergoes et al., 2008), approximating or leading slightly the onset of the first period of cooling at Kaipo.

Palynological changes similar to those recorded at Kaipo bog are evident at another central North Island montane pollen site at Otamangakau (Turney et al., 2003). At Otamangakau, the onset of the cooling signal approximately coincides with deposition of the Waiohau tephra (erupted ca. 14.0 cal. ka BP) whereas at Kaipo cooling began at ca. 13.8 cal. ka BP, around 200 years later. This apparent minor difference in timing may be due to differences in sampling and chronological resolution between the two records. Several other central North Island pollen sites also show indications of moderate cooling centred on ca. 14.0 cal. ka BP, with sustained warming renewed at ca. 12.5 cal. ka BP (Wilmshurst et al., 2007). At Okarito wetland, on the west coast of South Island, cooling began ca. $15.0 \mathrm{cal}$. ka BP and cool conditions persisted until ca. 13.5 cal. ka BP (Newnham et al., 2007b, 2012). In contrast, at Pukaki crater, located near sea level in Auckland in northern North Island, there is little if any ACR signal, although the sampling resolution here is poor, and a signal of cooler conditions at ca. 12.8 cal. ka BP is based on a single pollen sample (Newnham et al., 2012; Barrell et al., in press). The minor temperature decline at Pukaki, unlike the Kaipo sequence, has no accompanying lithostratigraphic change (Sandiford et al., 2003). Stephens et al. (2012 a, 2012 b) reported that at Lake Pupuke, also in the Auckland area, a period of enhanced 
erosional influx and reduced biomass productivity occurred from ca. 14.5 to 13.8 cal. ka BP, contrasting with a marked increase in biomass productivity and high diatom flux from ca. 13.8 to 12.8 cal. ka BP. At nearby Onepoto maar, however, there is multiproxy evidence for a drier and possibly cooler episode starting ca. $13.8 \mathrm{cal}$. ka BP and ending ca. $12.4 \mathrm{cal}$. ka BP (Augustinus et al., 2012).

Newnham et al. (2012) concluded from the pollen site at Okarito and also from the Boundary Stream tarn record of Vandergoes et al. (2008) that Lateglacial temperature profiles in the central South Island correspond closely with Southern Ocean records that show a pattern similar to the ACR defined from Antarctic ice core records (e.g. Pahnke et al., 2003; Pahnke and Sachs, 2006; Calvo et al., 2007; Anderson et al., 2009). Similarly, Bostock et al. (in press) reported a slight enrichment in $\delta^{18} \mathrm{O}_{\text {planktic }}$, decrease in sea-surface temperatures, and a reduction in intermediate and deep water circulation during the ACR (between ca. 14 and 12.5 cal. ka BP), and García et al. (2012) demonstrated that the onset of glacier advance in the Torres del Paine region of south Patagonia, Chile, during the early part of the ACR, was contemporaneous with an inferred decline in the Southern Ocean upwelling, and likely reduced $\mathrm{CO}_{2}$ outgassing of the Southern Ocean to the atmosphere at $14.6 \mathrm{cal}$. ka BP.

In contrast, conflicting evidence for the nature of Lateglacial climate comes from the Auckland area in northern North Island. At Pukaki crater, there is little discernible ACR pattern whereas at nearby Onepoto maar, Augustinus et al. $(2011,2012)$ attributed an episode of drier/cooler climate ca. 13.8 to 12.4 cal. ka BP to a delayed impact of the ACR. Conversely, nearby Lake Pupuke provides possible evidence of cooler conditions from ca. 14.5 to 13.8 cal. ka BP by way of increased sediment flux and decreased biologic productivity (Stephens et al., 2012 a, 2012 b). In eastern North Island, the montane Kaipo bog record displays a distinct Lateglacial cool episode that commenced about 300 years into ACR chronozone and continued into the first ca. 300 years of the GS-1/YD chronozone. A similar 
slight degree of overlap into the early GS-1/YD chronozone was reported in south Patagonia where the Lateglacial recession of glaciers had occurred by 12.5 cal. ka BP (García et al., 2012) (cf. Glasser et al., 2012). Earlier, Massaferro et al. (2009) used chironomid and pollen data from the Huelmo site in northwest Patagonia, Chile, to show that cold-wet conditions during the early Huelmo Mascardi Cold Reversal from ca. 13.5 to ca. 12.8 cal. ka BP were followed by cold-dry conditions from ca. 12.8 to 11.5 cal. ka BP.

The Lateglacial cool episode at Kaipo and Onepoto is broadly consistent with patterns evident in sea-surface temperature reconstructions offshore which show a muted response and cooling that lags the initiation of the ACR (Samson et al., 2005; Carter et al., 2008; Augustinus et al., 2011; Newnham et al., 2012).

We observe that a short 'stutter' of two steps is evident in some ice-core records about midway during the ACR interval, such as those shown by dust-flux and deuterium $(\delta \mathrm{D})$ records from the EPICA core, Antarctica (Delmonte et al., 2002; Jouzel, 2004; Newnham et al., 2012). A cold event in two phases was also recorded in southern Chile in varved sediments from Lago Puyehue (Boës and Fagel, 2008). At Boundary Stream tarn in central South Island, Vandergoes et al. (2008) showed that the Lateglacial cool episode there (ca. 14.2 to 13.2 cal. ka BP) contained a short-lived interruption of about 100 years at ca. 13.9 cal. ka BP before pronounced cool conditions resumed, and the ACR-related glacier advance inferred for Pukaki glacier in the Southern Alps ca. 13.0 cal. ka by Putnam et al. (2010, p. $703)$ is depicted as a possible two-phase event. In Auckland, Augustinus et al. (2011, 2012) suggested that the drying/cooling episode recorded from Onepoto maar sediments (ca. 13.8 to 12.4 cal. ka BP) was briefly interrupted for about 200 years from ca. 13.2 to 13.0 cal. ka BP. If the ages are accurate, this similarity in the structure of the cool episodes at Boundary Stream tarn and Onepoto maar, each being interrupted by a partial recovery for possibly ca. 
100 to 200 years, is broadly consistent with the latitudinal patterns in the ACR signal suggested for the New Zealand archipelago by Newnham et al. (2012).

Possible latitudinal controls were similarly invoked for the manifestation of the ACR signal in southern South America (Moreno et al., 2009; Strelin et al., 2011; García et al., 2012). In southern Patagonia in Argentina, Moreno et al. (2012) suggested that southwesterly winds intensified between 14.6 and 12.6 cal. ka BP (during the ACR) but then shifted polewards (weakened) between 12.6 and 11.6 cal. ka BP (during the YD/GS-1). Similarly, at Laguna Potrok Aike in southeast Patagonia, Jouve et al. (in press) and Massaferro et al. (in press) used evidence from geochemical analyses, diatom and chironomid variations, and a chironomid temperature transfer function (Massaferro and Larocque-Tobler, 2013), to demonstrate that conditions were cooler during the ACR chronozone than during the YD chronozone (see also Hahn et al., in press). García et al. (2012) suggested that the prominent expression of the ACR by the advance of outlet glaciers in Torres del Paine at $51^{\circ} \mathrm{S}$ in south Patagonia, reaching a maximum extent by ca. 14,200 \pm 560 cal. yr BP, coincided with a northward shift of the south-westerly wind belt. The timings of these events are broadly consistent with the timings of climatic changes in this period we have reported here for the New Zealand region.

\section{Conclusions}

To help the development of the New Zealand climate event stratigraphy (NZ-CES) as part of the NZ-INTIMATE project (Barrell et al., in press), we have firstly obtained new calendar ages for 24 widespread marker tephras erupted since 30,000 cal. years ago in New Zealand. The new ages additionally facilitate the use of the tephras as chronostratigraphic 
dating tools for various palaeoenvironmental applications, including marine reservoir age estimations, as well as volcanological and other geological applications. We developed 95\%probability age models using three methods: (i) ${ }^{14} \mathrm{C}$-based wiggle-match dating using treering sequences to date two late-Holocene tephras (these results published previously); (ii) flexible depositional age modelling using two Bayesian-based modelling programs, Bacon and OxCal's $P \_S e q u e n c e$ function, together with the IntCal09 data set (corrected for interhemispheric offset), to date 16 Lateglacial and Holocene tephras at the high-resolution Kaipo bog sequence; and (iii) OxCal-based Tau_Boundary Bayesian procedures to calibrate ${ }^{14} \mathrm{C}$ ages on six Holocene tephras and eight pre-Holocene tephras using either the SHCal04 data set or the IntCal09 data set (corrected for interhemispheric offset) as appropriate.

The new ages are summarised in Table 1. The ages derived using Bacon modelling are more conservative, and therefore are preferred over the more-precise OxCal-derived ages. Most Bacon-generated ages are, in any event, similar to those obtained using the $P \_$Sequence modelling, the exceptions being the ages obtained for Rerewhakaaitu and Tuhua tephras. All data and procedures have been formally documented (Table S1; Tables 2 and 3; Fig. 3) to allow the chronology to be readily revised. Of the key marker tephras, the ages of four in particular have been changed by ca. 400 years or more in comparison with the ages reported by D.J. Lowe et al. (2008): Okaia (now ca. $28.6 \pm 1.4$ cal. ka BP), Kawakawa/Oruanui (ca. $25.4 \pm 0.16$ cal. ka BP), Waiohau (ca. $14.0 \pm 0.16$ cal. ka BP), and Tuhua (ca. $6.6 \pm 0.55$ cal. ka BP). Ages on several tephras, notably Okaia, Poihipi, Te Rere, and Tuhua, remain very imprecise, however, with errors exceeding 500 cal. years. New work is required to improve these ages.

Secondly, we have re-dated the timing of the Lateglacial cool episode (climate event NZce-3), formerly called the Lateglacial climate reversal, as recorded at Kaipo bog, using both Bacon and OxCal-based $P \_S e q u e n c e$ modelling, and the IntCal09 data set. The ca. 
1200-yr-long cool episode, indicated by lithostratigraphic changes in the Kaipo peat sequence and accompanying pollen evidence, began ca. 13,739 \pm 125 cal. yr BP and ended ca. 12,550 \pm 140 cal. yr BP (mid-point ages of the 95\% HPD regions, derived using Bacon), an age range confirmed using the $P_{-}$Sequence modelling from which almost identical ages were obtained.

The cool episode at Kaipo (ca. 13.8-12.6 cal. ka BP) overlaps much of the Antarctic Cold Reversal chronozone (ca. 14.1-12.4 or ca. 14.6 to 12.8 cal. ka: García et al., 2012) as well as the early part of the Greenland Stadial-1/Younger Dryas chronozone (ca. 12.9-11.7 cal. ka BP). The timing of the cool episode at Kaipo is broadly consistent with latitudinal patterns in the ACR signal suggested for the New Zealand archipelago from marine and terrestrial records (e.g. Carter et al., 2008; Putnam et al., 2010; Newnham et al., 2012), and also with many (but not all) records from southern South America including Patagonia in particular (e.g. Moreno et al., 2009, 2012; Strelin et al., 2011; García et al., 2012). 


\section{Acknowledgements}

We acknowledge the leading roles of Brent Alloway and Jamie Shulmeister who, together with Rewi Newnham, initiated and developed the NZ-INTIMATE project, and those of Marcus Vandergoes, Peter Almond, David Barrell, Lionel Carter, Andrew Lorrey, Paul Williams, and others, in helping its continuation. We are most grateful to reviewers Simon Blockley and Andrew Hammond, and especially David Barrell, whose comments improved the paper markedly. We thank Chris Bronk Ramsey, Chris Ward, Vince Neall, Colin Wilson, and Kerri Lanigan for helpful advice or information, and David Palmer for providing climate data for Kaipo bog. Roland Gehrels, Teresa Giles, Chris Ward (who also provided Fig. 2), and Jonathan Palmer are thanked for help with field work at Kaipo. Roger Sparks, Christine Prior, and Ian Nairn assisted with details relating to ${ }^{14} \mathrm{C}$ ages, Glenn Wigley and Geoff Kilgour allowed us to cite unpublished ${ }^{14} \mathrm{C}$ ages, and Irka Hajdas earlier provided great support in dating Kaipo peats using AMS and insight into OxCal. Rod Wallace identified the tree species represented by sample Wk20724, and Max Oulton prepared five of the figures (Figs.1, 3, and 8-10). We are grateful to the issue editors, particularly Brent Alloway and Jessica Reeves, for their encouragement and patience, and also to Debbie Barrett (journal manager, Elsevier) for her support during production. INQUA is acknowledged and thanked for the financial support of SACCOM Project 0907 (INTREPID Tephra) "Enhancing tephrochronology as a global research tool through improved fingerprinting and correlation techniques and uncertainty modelling", an initiative of the International Focus Group on Tephrochronology and Volcanism (INTAV), and of PALCOMM Project 0806 (“Australasian-INTIMATE Phase II"). This paper is an output of both the INTREPID and Australasian/NZ-INTIMATE projects. It is also an output of the SUPRAnet project (“Studying uncertainty in palaeoenvironmental reconstruction - a net”) led by Caitlin Buck 
whose expertise with Bayesian analysis helped inspire our work. We leave the last word to Francis Bacon (1561-1626) from his discussion about errors: "So it is in contemplation; if a man will begin with certainties, he shall end in doubts; but if he will be content to begin with doubts, he shall end in certainties." (Quoted from Spedding et al., 1859, p. 293.)

\section{Appendix A. Supplementary data}

Supplementary data related to this article can be found at http://dx.doi.org/10.1016/j.quascirev.2012.11.022. 


\section{References}

Alley, R.B., Mayewski, P.A., Stuiver, M., Taylor, K.C., Clark, P.U., 2007. Holocene climatic instability: a prominent, widespread event 8200 yr ago. Geology 25, 483-486.

Alloway, B.V., Lowe, D.J., Chan, R.P.K., Eden, D.N., Froggatt, P.C., 1994. Stratigraphy and chronology of the Stent tephra, a c. 4000 year old distal silicic tephra from Taupo Volcanic Centre, New Zealand. New Zealand Journal of Geology and Geophysics 37, $37-47$.

Alloway, B.V., Neall, V.E., Vucetich, C.G., 1995. Late Quaternary (post- 28,000 year B.P.) tephrostratigraphy of northeast and central Taranaki, New Zealand. Journal of the Royal Society of New Zealand 25, 385-458.

Alloway, B.V., Lowe, D.J., Barrell, D.J.A., Newnham, R.M., Almond, P.C., Augustinus, P.C., Bertler, N.A.N., Carter, L., Litchfield, N.J., McGlone, M.S., Shulmeister, J., Vandergoes, M.J., Williams, P.W., INTIMATE members, 2007. Towards a climate event stratigraphy for New Zealand over the past 30,000 years (NZ-INTIMATE project). Journal of Quaternary Science 22, 9-35.

Anderson, B., Mackintosh, A., 2006. Temperature change is the major driver of late-glacial and Holocene glacier fluctuations in New Zealand. Geology 34, 121-124.

Anderson, R.F., Ali, S., Bradtmiller, L.I., Nielsen, S.H., Fleisher, M.Q., Anderson, B.E., Burckle, L.H., 2009. Wind-driven upwelling in the Southern Ocean and the deglacial rise in atmospheric $\mathrm{CO}_{2}$. Science 323, 1443-1448

Applegate, P.J., Lowell, T.V., Alley, R.B., 2008. Comment on “Absence of cooling in New Zealand and the adjacent ocean during the Younger Dryas chronozone". Science 320, 746. Ascough, P., Cook, G., Dugmore, A., 2005. Methodological approaches to determining the marine radiocarbon reservoir effect. Progress in Physical Geography 29, 532-547. 
Augustinus, P., Bleakley, N., Deng, Y., Shane, P., Cochrane, U., 2008. Rapid change in early Holocene environments inferred from Lake Pupuke, Auckland City, New Zealand. Journal of Quaternary Science 23, 435-447.

Augustinus, P., D’Costa, D., Deng, Y., Hagg, J., Shane, P., 2011. A multi-proxy record of changing environments from ca. 30000 to 9000 cal. a BP: Onepoto maar palaeolake, Auckland, New Zealand. Journal of Quaternary Science 26, 389-401.

Augustinus, P., Cochrane, U., Kattel, G., D’Costa, D., Shane, P., 2012. Late Quaternary paleolimnology of Onepoto maar, Auckland, New Zealand: implications for the drivers of regional paleoclimate. Quaternary International 253, 18-31.

Austin, W.E.N., Bard, E., Hunt, J.B., Kroon, D., Peacock, J.D., 1995. The ${ }^{14}$ C age of the Icelandic Vedde Ash: implications for Younger Dryas marine reservoir age corrections. Radiocarbon 37, 53-62.

Barrell, D.J.A., Alloway, B.V., Shulmeister, J., Newnham, R.M. (editors) 2005. Towards a climate event stratigraphy for New Zealand over the past 30,000 years. Institute of Geological and Nuclear Sciences Science Report 2005/07. 12 pp. and poster.

Barrell, D.J.A., Andersen, B.G., Denton, G.H., 2011. Glacial geomorphology of the central South Island, New Zealand. GNS Science Monograph 27. 81 pp., 5 maps, and legend. Institute of Geological and Nuclear Sciences Ltd, Lower Hutt, New Zealand.

Barrell, D.J.A., Almond, P.C., Vandergoes, M.J., Lowe, D.J., Newnham, R.M., NZINTIMATE members, in press. A composite pollen-based stratotype for inter-regional evaluation of climatic events in New Zealand over the past 30,000 years (NZ-INTIMATE project). Quaternary Science Reviews

Beetham, R.D., McSaveney, M.J., Read, S.A.L., 2002. Four extremely large landslides in New Zealand. In: Rybář, J., Stemberk, J., Wagner, P. (editors), Landslides: Proceedings 
of the First European Conference on Landslides (Prague, Czech Republic, June 24-26, 2002). Swets and Zeitlinger/A.A. Balkema, Lisse, pp. 97-102.

Benny, L.A., Kennedy, N.M., Kirkman, J.H., Stewart, R.B., 1988. Mineralogical and textural discrimination of loess derived from a tephra near Rotorua, New Zealand. Australian Journal of Soil Research 26, 301-312.

Blaauw, M., Christen, J.A., 2005. Radiocarbon peat chronologies and environmental change. Journal of the Royal Statistical Society Series C (Applied Statistics) 54, 805-816.

Blaauw, M., Christen, J.A., 2011. Flexible paleoclimate age-depth models using an autoregressive gamma process. Bayesian Analysis 6, 457-474.

Blaauw, M., Heegaard, E., 2012. Estimation of age-depth relationships. In: Birks, H.J.B., Lotter, A.F., Juggins, S., Smol, J.P. (editors), Tracking environmental change using lake sediments. Data handling and numerical techniques. Developments in Paleoenvironmental Research 5, 379-413.

Blockley, S.P.E., Ramsey, C.B., Pyle, D.M., 2008. Improved age modelling and highprecision age estimates of late Quaternary tephras, for accurate palaeoclimate reconstruction. Journal of Volcanology and Geothermal Research 177, 251-262.

Blockley, S.P.E., Lane, C.S., Hardiman, M., Rasmussen, S.O., Seierstad, I.K., Steffensen, J.P., Svensson, A., Lotter, A.F., Turney, C.S.M., Ramsey, C.B., INTIMATE members, 2012. Synchronisation of palaeoenvironmental records over the last 60,000 years, and an extended INTIMATE event stratigraphy to 48,000 b2k. Quaternary Science Reviews 36, $2-10$.

Boës, X., Fagel, N., 2008. Timing of the late glacial and Younger Dryas cold reversal in southern Chile varved sediments. Paleolimnology 39, 267-281. 
Bondevik, S., Mangerud, J., Birks, H.H., Gulliksen, S., Reimer, P., 2006. Changes in North Atlantic radiocarbon reservoir ages during the Allerød and Younger Dryas. Science 312, $1514-1517$.

Booth, R.K., Jackson, S.T., Forman, S.L., Kutzbach, J.E., Bettis, E.A. III, Kreig, J., Wright, D.K., 2005. A severe centennial-scale drought in midcontinental North America 4200 years ago and apparent global linkages. The Holocene 15, 321-328.

Bostock, H.C., Barrows, T.T., Carter, L., Chase, Z., Cortese, G., Dunbar, G.B., Ellwood, M., Hayward, B., Howard, W., Neil, H.L., Noble, T.L., Mackintosh, A., Moss, P.T., Moy, A.D.,White, D., Williams, M.J.M., Armand, L.K., in press. A review of the Australian-New Zealand sector of the Southern Ocean over the last 30 ka (AusINTIMATE project). Quaternary Science Reviews http://dx.doi.org/10.1016/j.quascirev.2012.07.018 (online 29 August 2012)

Briggs, R.M., Lowe, D.J., Esler, W.R., Smith, R.T., Henry, M.A.C., Wehrmann, H., Manning, D.A., 2006. Geology of the Maketu area, Bay of Plenty, North Island, New Zealand Sheet V14 1:50 000. Bay of Plenty Regional Council and Department of Earth Sciences, University of Waikato, Occasional Report 26. 44 pp. and 1 map.

Bronk Ramsey, C., 2001. Development of the radiocarbon calibration program OxCal. Radiocarbon 43, 355-363.

Bronk Ramsey, C., 2008. Deposition models for chronological records. Quaternary Science Reviews 27, 42-60.

Bronk Ramsey, C., 2009a. Dealing with outliers and offsets in radiocarbon dating. Radiocarbon 51, 1023-1045.

Bronk Ramsey, C., 2009b. Bayesian analysis of radiocarbon dates. Radiocarbon 51, 337-360. Buck, M.D., Briggs, R.M., Nelson, C.S., 1981. Pyroclastic deposits and volcanic history of Mayor Island. New Zealand Journal of Geology and Geophysics 24, 449-467. 
Buck, C.E., Higham, T.F.G., Lowe, D.J. 2003. Bayesian tools for tephrochronology. The Holocene 13, 639-647.

Calvo, E., Pelejero, C., De Deckker, P., Logan, G.A., 2007. Antarctic deglacial pattern in a 30 kyr record of sea surface temperature offshore South Australia. Geophysical Research Letters 34, L13707, DOI:10.1029/2007GL029937 (pp.1-6).

Carter, L., Nelson, C.S., Neil, H.L., Froggatt, P.C., 1995. Correlation, dispersal, and preservation of the Kawakawa Tephra and other late Quaternary tephra layers in the Southwest Pacific ocean. New Zealand Journal of Geology and Geophysics 38, 29-46.

Carter, L., Neil, H.L., McCave, I.N., 2000. Glacial to interglacial changes in non-carbonate and carbonate accumulation in the SW Pacific Ocean, New Zealand. Palaeogeography, Palaeoclimatology, Palaeoecology 162, 333-356.

Carter, L., Manighetti, B., Ganssen, G., Northcote, L., 2008. Southwest Pacific modulation of abrupt climate change during the Antarctic Cold Reversal-Younger Dryas.

Palaeogeography, Palaeoclimatology, Palaeoecology 260, 284-298.

Chester, P.I., Prior, C.A., 2004. An AMS ${ }^{14}$ C pollen-dated sediment and pollen sequence from the late Holocene, southern coastal Hawke's Bay, New Zealand. Radiocarbon 46, $721-731$.

Christen, J.A. and Pérez, S., 2009. A new robust statistical model for radiocarbon data. Radiocarbon 51, 1047-1059.

Clarkson, B.R., Patel, R.N., Clarkson, B.D., 1988. Composition and structure of forest overwhelmed at Pureora, central North Island, New Zealand, during the Taupo eruption (c. A.D. 130). Journal of the Royal Society of New Zealand 18, 417-436.

Cole, J.W., 1970. Description and correlation of Holocene volcanic formations in the Tarawera-Rerewhakaaitu region. Transactions of the Royal Society of New Zealand Earth Sciences 8, 93-108. 
Danišík, M., Shane, P.A.R., Schmitt, A.K., Hogg, A.G., Santos, G.M., Storm, S., Evans, N.J., Fifield, L.K., Lindsay, J.M., 2012. Re-anchoring the late Pleistocene tephrochronology of New Zealand based on concordant radiocarbon ages and combined ${ }^{238} \mathrm{U} /{ }^{230} \mathrm{Th}$ disequilibrium and (U-Th)/He zircon ages. Earth and Planetary Science Letters 349-350, $240-250$.

Darragh, M., Cole, J.W., Nairn, I.A., Shane, P.A.R., 2006. Pyroclastic stratigraphy and eruption dynamics of the 21.9 ka Okareka and 17.6 ka Rerewhakaaitu eruption episodes from Tarawera Volcano, Okataina Volcanic Centre, New Zealand. New Zealand Journal of Geology and Geophysics 49, 309-328.

Davies, S.M., Abbott, P.M., Pearce, N.J.G., Wastegård, S., Blockley, S.P.E., 2012.

Integrating the INTIMATE records using tephrochronology: rising to the challenge. Quaternary Science Reviews 36, 11-27.

de Menocal, P.B. , 2001. Cultural responses to climate change during the Late Holocene. Science 292, 667-673.

Delmonte, B., Petit, J.R., Maggi, V., 2002. Glacial to Holocene implications of the new 27000-year dust record from the EPICA Dome C (East Antarctica) ice core. Climate Dynamics 18, 647-660.

Doughty, A.M., Anderson, B.M., Mackintosh, A.N., Kaplan, M.R., Vandergoes, M.J., Barrell, D.J.A., Denton, G.H., Schaefer, J.M., Chinn, T.J.H., Putnam, A.E., in press. Evaluation of Lateglacial temperature in the Southern Alps of New Zealand based on glacier modelling at Irishman Stream, Ben Ohau Range. Quaternary Science Reviews (DOI: 10.1016/j.quascirev.2012.09.013) 
Eden, D.N., Froggatt, P.C., Trustrum, N.A., Page, M.J., 1993. A multiple-source Holocene tephra sequence from Lake Tutira, Hawke's Bay, New Zealand. New Zealand Journal of Geology and Geophysics 36, 233-242.

Froggatt, P.C., Lowe, D.J., 1990. A review of late Quaternary silicic and some other tephra formations from New Zealand: their stratigraphy, nomenclature, distribution, volume, and age. New Zealand Journal of Geology and Geophysics 33, 89-109.

Froggatt, P.C., Rogers, G.M., 1990. Tephrostratigraphy of high-altitude peat bogs along the axial ranges, North Island, New Zealand. New Zealand Journal of Geology and Geophysics 33, 111-124.

García, J.L., Kaplan, M.R., Hall, B.L., Schaefer, J.M., Vega, R.M., Schwartz, R., Finkel, R., 2012. Glacier expansion in southern Patagonia throughout the Antarctic cold reversal. Geology 40, 859-862.

Gehrels, M.J., Lowe, D.J., Hazell, Z.J., Newnham, R.M., 2006. A continuous 5300-yr Holocene cryptotephrostratigraphic record from northern New Zealand and implications for tephrochronology and volcanic-hazard assessment. The Holocene 16, 173-187.

Gehrels, M.J., Newnham, R.M., Lowe, D.J., Wynne, S., Hazell, Z.J., Caseldine, C., 2008. Towards rapid assay of cryptotephra in peat cores: review and evaluation of selected methods. Quaternary International, 178, 68-84.

Gillespie, R., Hammond, A.P., Goh, K.M., Tonkin, P.J., Lowe, D.C., Sparks, R.J., Wallace, G., 1992. AMS dating of a late Quaternary tephra at Graham's Terrace, New Zealand. Radiocarbon 34, 21-27.

Glasser, N.F., Harrison, S., Schnabel, C., Fabel, D., Jansson, K.N., 2012. Younger Dryas and early Holocene age glacier advances in Patagonia. Quaternary Science Reviews 58, 7-17. Golledge, N.R., Mackintosh, A.M., Anderson, B.M., Buckley, K.M., Doughty, A.M., Barrell, D.J.A., Denton, G.H., Vandergoes, M.J., Andersen, B.G., Schaefer, J.M., 2012. Last 
Glacial Maximum climate in New Zealand inferred from a modelled Southern Alps icefield. Quaternary Science Reviews 46, 30-45.

Grant-Taylor, T.L., Rafter, T.A., 1963. New Zealand natural radiocarbon measurements I-V. Radiocarbon 5, 18-62.

Grant-Taylor, T.L., Rafter, T.A., 1971. New Zealand radiocarbon age measurements -6. New Zealand Journal of Geology and Geophysics 14, 364-402.

Hahn, A., Kliem, P., Ohlendorf, C., Zolitschka, B., Rosén, P., The PASADO Science Team, in press. Climate induced changes as registered in inorganic and organic sediment components from Laguna Potrok Aike (Argentina) during the past 51 ka. Quaternary Science Reviews (DOI:10.1016/j.quascirev.2012.09.015).

Hajdas, I., Lowe, D.J., Newnham, R.M., Bonani, G., 2006. Timing of the late-glacial climate reversal in the Southern Hemisphere using high resolution radiocarbon chronology for Kaipo bog, New Zealand. Quaternary Research 65, 340-345.

Healy, J., 1964. Dating the younger volcanic eruptions of the Taupo region. New Zealand Geological Survey Bulletin 73, 7-42.

Hogg, A.G., McCraw, J.D., 1983. Late Quaternary tephras of Coromandel Peninsula, North Island, New Zealand: a mixed peralkaline and calkalkaline tephra sequence. New Zealand Journal of Geology and Geophysics 26, 163-187.

Hogg, A.G., Lowe, D.J., Hendy, C.H., 1987. University of Waikato radiocarbon dates I. Radiocarbon 29, 263-301.

Hogg, A.G., Higham, T.F.G., Lowe, D.J., Palmer, J., Reimer, P., Newnham, R.M., 2003. A wiggle-match date for Polynesian settlement of New Zealand. Antiquity 77, 116-125.

Hogg, A.G., Palmer, J.G., Boswijk, G., Turney, C., 2011. High-precision radiocarbon measurements of tree-ring dated wood from New Zealand: 195 BC-AD 995. Radiocarbon $53,529-542$. 
Hogg, A.G., Lowe, D.J., Palmer, J.G., Boswijk, G., Bronk Ramsey, C.J., 2012. Revised calendar date for the Taupo eruption derived by ${ }^{14} \mathrm{C}$ wiggle-matching using a New Zealand kauri ${ }^{14} \mathrm{C}$ calibration data set. The Holocene 22, 439-449.

Holt, K.A., Lowe, D.J., Hogg, A.G., Wallace, R.C., 2011. Distal occurrence of mid-Holocene Whakatane Tephra on the Chatham Islands, New Zealand, and potential for cryptotephra studies. Quaternary International 246, 344-351.

Ikehara, K., Danhara, T., Yamashita, T., Tanahashi, M., Morita, S., Ohkushi, K., 2011. Paleoceanographic control on a large marine reservoir effect offshore of Tokai, south of Japan, NW Pacific, during the last glacial maximum-deglaciation. Quaternary International 246, 213-221

Jouve, G., Francus, P., Lamoureux, S., Provencher-Nolet, L., Hahn, A., Haberzettl, T., Fortin, D., Nuttin, L., The PASADO Science Team, in press. Microsedimentological characterization using image analysis and $\mu-\mathrm{XRF}$ as indicators of sedimentary processes and climate changes during Lateglacial at Laguna Potrok Aike, Santa Cruz, Argentina. Quaternary Science Reviews http://dx.doi.org/10.1016/j.quascirev.2012.06.003 (online 17 July 2012)

Jouzel, J., 2004. EPICA Dome C ice cores deuterium Data. IGBP PAGES, World Data Center for Paleoclimatology, Data Contribution series \# 2004-038. NOAA/NGDC Paleoclimatology Program, Boulder CO, USA. DOI:10.3334/CDIAC/cli.007.

Kaplan, M.R., Schaefer, J.M., Denton, G.H., Barrell, D.J.A., Chinn, T.J.H., Putnam, A.E., Andersen, B.G., Finkel, R.C., Schwartz, R., Doughty, A., 2010. Glacier retreat in New Zealand during the Younger Dryas Stadial. Nature 467, 194-197.

Kilgour, G.N., 2002. The nature and dynamics of the Rotorua eruptive episode, Okataina Volcanic Centre, Taupo Volcanic Zone. Unpublished MSc thesis, University of Waikato, Hamilton, New Zealand. 
Kilgour, G.N., Smith, R.T., 2008. Stratigraphy, dynamics, and eruption impacts of the dual magma Rotorua eruptive episode, Okataina Volcanic Centre, New Zealand. New Zealand Journal of Geology and Geophysics 51, 367-378.

Kirkbride, M.P., Winkler, S., 2012. Correlation of Late Quaternary moraines: impact of climate variability, glacier response, and chronological resolution. Quaternary Science Reviews 46, 1-29.

Lanigan, K.M., 2012. Straigraphy and character of tephric loess deposits aged from c. 33 to $9.5 \mathrm{cal} \mathrm{ka}$ in the Rotorua area, northern New Zealand, and some inferences about past climates. Unpublished MSc thesis, University of Waikato, Hamilton, New Zealand.

Leathwick, J.R., Wilson, G., Stephens, R.T.T., 2002. Climate surfaces for New Zealand. Landcare Research contract report LC9798/126. Landcare Research, Hamilton, 22 pp.

Leathwick, J., Wilson, G., Rutledge, D., Wardle, P., Morgan, F., Johnston, K., McLeod, M., Kirkpatrick, R., 2003. Land Environments of New Zealand. Ministry for the Environment, Wellington, and Manaaki Whenua Landcare Research, Hamilton. 184 pp and 2 map sheets. Lemieux-Dudon, B., Blayo, E., Petit, J-R., Waelbroeck, C., Svensson, A., Ritz, C., Barnola, J-M., Narcisi, B.M., Parrenin, F., 2010. Consistent dating for Antarctic and Greenland ice cores. Quaternary Science Reviews 29, 8-20.

Leonard, G.S., Begg, J.G., Wilson, C.J.J. (Compilers), 2010. Geology of the Rotorua area: scale 1: 250,000. Institute of Geological and Nuclear Sciences 1: 250,000 geological map 5. 99 pp. and 1 map. Institute of Geological and Nuclear Sciences Ltd, Lower Hutt, New Zealand.

Litchfield, N.J., Berryman, K.R., 2005. Correlation of fluvial terraces within the Hikurangi Margin, New Zealand: implications for climate and baselevel controls. Geomorphology 68, 291-313. 
Litchfield, N.J., Berryman, K.R., 2006. Relations between postglacial fluvial incision rates and uplift rates in the North Island, New Zealand. Journal of Geophysical Research 111, F02007, DOI:10.1029/2005JF000374 (pp. 1-15).

Lorrey, A.M., Vandergoes, M., Almond, P., Renwick, J., Stephens, T., Bostock, H., Mackintosh, A., Newnham, R., Williams, P.W., Ackerley, D., Neil, H., Fowler, A.M., 2012. Palaeocirculation across New Zealand during the last glacial maximum at $\sim 21 \mathrm{ka}$. Quaternary Science Reviews 36, 189-213.

Lowe, D.J., 1988. Stratigraphy, age, composition, and correlation of late Quaternary tephras interbedded with organic sediments in Waikato lakes, North Island, New Zealand. New Zealand Journal of Geology and Geophysics 31, 125-165.

Lowe, D.J., 2011. Tephrochronology and its application: a review. Quaternary Geochronology 6, 107-153.

Lowe, D.J., Hogg, A.G., 1986. Tephrostratigraphy and chronology of the Kaipo Lagoon, an 11,500 year-old montane peat bog in Urewera National Park, New Zealand. Journal of the Royal Society of New Zealand 16, 25-41.

Lowe, D.J., Newnham, R.M., Ward, C.M., 1999. Stratigraphy and chronology of a 15 ka sequence of multi-sourced silicic tephras in a montane peat bog, eastern North Island, New Zealand. New Zealand Journal of Geology and Geophysics 42, 565-579.

Lowe, D.J., Newnham, R.M., Blaauw, M., Hajdas, I., Hogg, A.G., 2007. Timing of the lateglacial climate reversal in Southern Hemisphere: update using high-resolution Bayesian age modelling (Bpeat) at Kaipo bog, New Zealand. Quaternary International 167-168 (Supplement), 252.

Lowe, D.J., Shane, P.A.R., Alloway, B.V., Newnham, R.M., 2008. Fingerprints and age models for widespread New Zealand tephra marker beds erupted since 30,000 years ago: a framework for NZ-INTIMATE. Quaternary Science Reviews 27, 95-126. 
Lowe, J.J., Rasmussen, S.O., Björck, S., Hoek, W.Z., Steffensen, J.P., Walker, M.J.C., Yu, Z.C., INTIMATE group, 2008. Synchronisation of palaeoenvironmental events in the North Atlantic region during the Last Termination: a revised protocol recommended by the INTIMATE group. Quaternary Science Reviews 27, 6-17.

Lowe, D.J., Wilson, C.J.N., Newnham, R.M., Hogg, A.G., 2010. Dating the Kawakawa/Oruanui eruption: comment on "Optical luminescence dating of a loess section containing a critical tephra marker horizon, SW North Island of New Zealand” by R. Grapes et al. Quaternary Geochronology 5, 493-496.

Lowe, D.J., Lanigan, K.M., Palmer, D.J., 2012. Where geology meets pedology: Late Quaternary tephras, loess, and paleosols in the Mamaku Plateau and Lake Rerewhakaaitu areas. Geoscience Society of New Zealand Miscellaneous Publication 134B, 2.1-2.45.

Massaferro, J., Larocque-Tobler, I., 2013. Using a newly developed chironomid transfer function for reconstructing mean annual air temperature at Lake Potrok Aike, Patagonia, Argentina. Ecological Indicators 24, 201-210.

Massaferro, J., Moreno, P.I., Denton, G.H., Vandergoes, M.J., Dieffenbacher-Krall, A., 2009. Chironomid and pollen evidence for climate fluctuations during the Last Glacial Termination in NW Patagonia. Quaternary Science Reviews 28, 517-525.

Massaferro, J., Recasens, C., Larocque-Tobler, I., Maidana, N.I., in press. Major lake level fluctuations and climate changes for the past 16,000 years as reflected by diatoms and chironomids preserved in the sediment of Laguna Potrok Aike, southern Patagonia. Quaternary Science Reviews http://dx.doi.org/10.1016/j.quascirev.2012.07.026 (online 7 September 2012)

McCormac, F.G., Reimer P.J., Hogg A.G., Higham T.F.G., Baillie M.G.L., Palmer J.G., Stuiver, M., 2002. Calibration of the radiocarbon time scale for the Southern Hemisphere: AD 1850-950. Radiocarbon 44, 641-651. 
McCormac, F.G., Hogg, A.G., Blackwell, P.G., Buck, C.E., Higham, T.F.G., Reimer, P.J., 2004. SHCal04 Southern Hemisphere calibration, 0-11.0 cal kyr BP. Radiocarbon 46, 1087-1092.

McGlone, M.S., Neall, V.E., 1994. The late Pleistocene and Holocene vegetation history of Taranaki ,North Island, New Zealand. New Zealand Journal of Botany 32, 251-269.

McGlone, M.S., Turney, C.S.M., Wilmshurst, J.M., 2004. Late-glacial and Holocene vegetation and climatic history of the Cass Basin, central South Island, New Zealand. Quaternary Research 62, 267-279.

McGlone, M.S., Turney, C.S.M., Wilmshurst, J.M., Renwick, J., Pahnke, K., 2010. Divergent trends in land and ocean temperature in the Southern Ocean over the past 18,000 years. Nature Geoscience 3, 622-626.

McKelvey, P.J., 1973. The pattern of the Urewera forests. New Zealand Forest Research Institute Technical Paper 59, 1-48.

Menounos, B., Clague, J.J., Osborn, G., Luckman, B.H., Lakeman, T.R., Minkus, R., 2008. Western Canadian glaciers advance in concert with climate change circa $4.2 \mathrm{ka}$. Geophysical Research Letters 35, L07501 (pp.1-6).

Molloy, C., Shane, P., Augustinus, P., 2009. Eruption recurrence rates in a basaltic volcanic field based on tephra layers in maar sediments: implications for hazards in the Auckland volcanic field. Geological Society of America Bulletin 121, 1666-1677.

Moore, P.R., 1979. Rock types and surface deposits: Urewera Waikaremoana, 1:100,000. NZMS 290 W17/18. New Zealand Department of Scientific and Industrial Research, Wellington.

Moreno, P., Kaplan, M.R., François, J.P., Villa-Martinez, R., Moy, C.M., Stern, C.R., Kubik, P.W., 2009. Renewed glacial activity during the Antarctic cold reversal and persistence of cold conditions until 11.5 ka in southwestern Patagonia. Geology 37, 375-378. 
Moreno, P.I., Villa-Martínez, R., Cárdenas, M.L., Sagredo, E.A., 2012. Deglacial changes of the southern margin of the southern westerly winds revealed by terrestrial records from SW Patagonia (52 $\mathrm{S})$. Quaternary Science Reviews 41, 1-21.

Moriwaki, H., Suzuki, T., Murata, M., Ikehara, M., Machida, H., Oba, T., Lowe, D.J., 2011. Sakurajima-Satsuma (Sz-S) and Noike-Yumugi (N-Ym) tephras: new tephrochronological marker beds for the last deglaciation, southern Kyushu, Japan. Quaternary International 246, 203-212.

Nairn, I.A. 1980. Source, age, and eruptive mechanisms of Rotorua Ash. New Zealand Journal of Geology and Geophysics 23, 193-207.

Nairn, I.A. 1992. The Te Rere and Okareka eruptive episodes-Okataina Volcanic Centre, Taupo Volcanic Zone, New Zealand. New Zealand Journal of Geology and Geophysics 35, 93-108.

Nairn, I.A., 2002. Geology of the Okataina Volcanic Centre, scale 1:50 000. Institute of Geological and Nuclear Sciences geological map 25. 156 pp. and 1map. Institute of Geological and Nuclear Sciences Ltd, Lower Hutt, New Zealand.

Newnham, R.M., Lowe, D.J., 2000. Fine-resolution pollen record of late-glacial climate reversal from New Zealand. Geology 28, 759-762.

Newnham, R.M., Lowe, D.J., 2001. The search for Younger Dryas cooling in New Zealand using tephrochronology. Les Dossiers de l'Archeo-Logis 1, 61-65.

Newnham, R.M., de Lange, P.J., Lowe, D.J., 1995a. Holocene vegetation, climate, and history of a raised bog complex, northern New Zealand, based on palynology, plant macrofossils and tephrochronology. The Holocene 5, 267-282.

Newnham, R.M., Lowe, D.J., Wigley, G.N.A., 1995b. Late Holocene palynology and palaeovegetation of tephra-bearing mires at Papamoa and Waihi Beach, western Bay of 
Plenty, North Island, New Zealand. Journal of the Royal Society of New Zealand 25, $283-300$.

Newnham, R.M., Lowe, D.J., McGlone, M.S., Wilmshurst, J.M., Higham, T.F.G., 1998. The Kaharoa Tephra as a critical datum for earliest human impact in northern New Zealand. Journal of Archaeological Science 25, 533-544.

Newnham, R.M., Eden, D.N., Lowe, D.J. and Hendy, C.H., 2003. Rerewhakaaitu Tephra, a land-sea marker for the Last Termination in New Zealand, with implications for global climate change. Quaternary Science Reviews 22, 289-308.

Newnham, R.M., Lowe, D.J., Giles, T., Alloway, B.V., 2007a. Vegetation and climate of Auckland, New Zealand, since ca. 32000 cal. yr ago: support for an extended LGM. Journal of Quaternary Science 22, 517-534.

Newnham, R.M., Vandergoes, M.J., Hendy, C.H., Lowe, D.J., Preusser, F., 2007b. A terrestrial palynological record for the last two glacial cycles from southwestern New Zealand. Quaternary Science Reviews 26, 517-535.

Newnham, R.M., Vandergoes, M.J., Garnett, M., Lowe, D.J., Prior, C., Almond, P.J., 2007c. Test of AMS ${ }^{14} \mathrm{C}$ dating of pollen concentrates using tephrochronology. Journal of Quaternary Science 22, 37-51.

Newnham, R.M., Vandergoes, M.J., Sikes, E., Carter, L., Wilmshurst, J.M., Lowe, D.J., McGlone, M.S., Sandiford, A., 2012. Does the bipolar seesaw extend to the terrestrial southern mid-latitudes? Quaternary Science Reviews 36, 214-222.

Newnham, R.M., McGlone, M.S., Moar, N., Wilmshurst, J.M., Marcus Vandergoes, M.J., in press. The vegetation cover of New Zealand at the Last Glacial Maximum. Quaternary Science Reviews http://dx.doi.org/10.1016/j.quascirev.2012.08.022 (online 3 October 2012) 
Nicolussi, K., Schlüchter, C., 2012. The 8.2 ka event - calendar-dated glacier response in the Alps. Geology 40, 819-822.

Ohkushi, K., Uchida, M., Aoki, K., Yoneda, M., Ikehara, K., Monoshima, K., Kawahata, H., Tada, R., Murayama, M., Shibata, Y., 2007. Radiocarbon marine reservoir ages in the northwestern Pacific off Hokkaido Island, Japan, during the last deglacial period. Radiocarbon 49, 963-968.

Olsen, J., Gudmundsdóttir, E.R., Björck, S., Odgaard, B.V., Heinemeier, J., 2010. Revised age estimate of the Mjáuvótn tephra A on the Faroe Islands based on Bayesian modelling of ${ }^{14} \mathrm{C}$ dates from two lake sequences. Journal of Quaternary Science 25, 612-616.

Page, M.J., Trustrum, N.A., Orpin, A.R., Carter, L., Gomez, B., Cochran, U.A., Mildenhall, D.C., Rogers, K.M., Brackley, H.L., Palmer, A.S., Northcote, L., 2010. Storm frequency and magnitude in response to Holocene climate variability, Lake Tutira, north-eastern New Zealand. Marine Geology 270, 30-44.

Pahnke, K., Sachs, J.P., 2006. Sea surface temperatures of southern midlatitudes 0-160 kyr B.P. Paleoceanography 21, PA2003, DOI: 10.1029/2005PA001191 (pp. 1-17).

Pahnke, K., Zahn, R., Elderfield, H., Schulz, M., 2003. 340,000 year centennial scale marine record of Southern Hemispheric climate oscillation. Science 301, 948-952.

Palmer, J., Ogden, J., Patel, R.N., 1988. A 426-year floating tree-ring chronology from Phyllocladus trichomanoides buried by the Taupo eruption at Pureora, central North Island, New Zealand. Journal of the Royal Society of New Zealand 18, 407-415.

Pardo, N., Cronin, S.J., Palmer, A.S., Németh, K., 2012.Reconstructing the largest explosive eruptions of Mt. Ruapehu, New Zealand: lithostratigraphic tools to understand subplinianplinian eruptions at andesitic volcanoes. Bulletin of Volcanology 74, 617-640.

Pullar, W.A., 1973. Isopachs of tephra, central North Island, New Zealand. Scale 1: 1,000,000. In: Pullar, W.A., Birrell, K.S. (compilers), Age and distribution of late 
Quaternary pyroclastic and associated cover deposits of the Rotorua and Taupo area. New Zealand Soil Survey Report 1 (part 2).

Pullar, W.A., Heine, J.C., 1971. Ages, inferred from ${ }^{14} \mathrm{C}$ dates, of some tephra and other deposits from Rotorua, Taupo, Bay of Plenty, Gisborne and Hawke’s Bay districts. Proceedings of Radiocarbon Users' Conference, Wellington, pp. 118-138.

Putnam, A.E., Denton, G.H., Schaefer, J.M., Barrell, D.J.A., Andersen, B.G., Finkel, R.C., Schwartz, R., Doughty, A.M., Kaplan, M.R., Schlüchter, C. 2010. Glacier advance in southern middle-latitudes during the Antarctic Cold Reversal. Nature Geoscience 3, 700704.

Reimer, P.J., Baillie, M.G.L., Bard, E., Bayliss, A., Beck, J.W., Bertrand, C.J.H., Blackwell, P.G., Buck, C.E., Burr, G.S., Cutler, K.B., Damon, P.E., Edwards, R.L., Fairbanks, R.G., Friedrich, M., Guilderson, T.P., Hogg, A.G., Hughen, K.A., Kromer, B., McCormac, F.G., Manning, S., Bronk Ramsey, C., Reimer, R.W., Remmele, S., Southon, J.R., Stuiver, M., Talamo, S., Taylor, F.W., van der Plicht, J., Weyhenmeyer, C.E., 2004. IntCal04 terrestrial radiocarbon age calibration, 0-26 cal kyr BP. Radiocarbon 46, 1029-1058.

Reimer, P.J., Baillie, M.G.L., Bard, E., Bayliss, A., Beck, J.W., Blackwell, O.G., Bronk Ramsey, C., Buck, C.E., Burr, G.S., Edwards, R.L., Friedrich, M., Grootes, P.M., Guilderson, T.P., Hajdas, I., Heaton, T.J., Hogg, A.G., Hughen, K.A., Kaiser, K.F., Kromer, B., McCormac, F.G., Manning, S.W., Reimer, R.W., Richards, D.A., Southon, J.R., Talamo, S., Turney, C.S.M., van der Plicht, J., Weyhenmeyer, C.E. 2009. IntCal09 and Marine09 radiocarbon age calibration curves, 0-50,000 years cal BP. Radiocarbon 51, $1111-1150$.

Samson, C.R., Sikes, E.L., Howard, W.R., 2005. Deglacial paleoceanographic history of the Bay of Plenty, New Zealand. Paleoceanography 20, PA4017, DOI: 10.1029/2004PA001088 (pp. 1-12). 
Sandiford, A., Alloway, B.V., Shane, P., 2001. A 28,000-6600 cal yr record of local and distal volcanism preserved in a paleolake, Auckland, New Zealand. New Zealand Journal of Geology and Geophysics 44, 323-336.

Sandiford, A., Horrocks, M., Newnham, R.M., Ogden, J., Alloway, B.V., 2002. Environmental change during the Last Glacial Maximum (ca 25,500-16,500 years BP) at Mt Richmond, Auckland Isthmus, New Zealand. Journal of the Royal Society of New Zealand 32, 155-167.

Sandiford, A., Newnham, R., Alloway, B., Ogden, J., 2003. A 28 000-7600 cal yr BP pollen record of vegetation and climate change from Pukaki Crater, northern New Zealand. Palaeogeography, Palaeoclimatology, Palaeoecology 201, 235-247.

Shane, P.A.R., 2005. Towards a comprehensive distal andesitic tephrostratigraphic framework for New Zealand based on eruptions from Egmont volcano. Journal of Quaternary Science 20, 45-57.

Shane, P.A.R., Hoverd, J., 2002. Distal record of multi-sourced tephra in Onepoto Basin, Auckland, New Zealand: implications for volcanic chronology, frequency and hazards. Bulletin of Volcanology 64, 441-454.

Shane, P.A.R., Smith, V.C., Lowe, D.J., Nairn, I.A., 2003. Re-identification of c. 15,700 cal yr BP tephra bed at Kaipo Bog, eastern North Island: implications for dispersal of Rotorua and Puketarata tephra beds. New Zealand Journal of Geology and Geophysics 46, 591596.

Shane, P.A.R., Sikes, E.L., Guilderson, T.P., 2006. Tephra beds in deep sea cores off northern New Zealand: implications for the history of Taupo Volcanic Zone, Mayor Island and White Island volcanoes. Journal of Volcanology and Geothermal Research 154, 276290. 
Sikes, E.L., Samson, C.R., Guilderson, T.P., Howard, W.R., 2000. Old radiocarbon ages in the southwest Pacific Ocean during the last glacial period and deglaciation. Nature 405, $555-559$.

Spedding, J., Ellis, R.L., Heath, D.D. (Collectors and Editors), 1859. The works of Francis Bacon, Vol. 3. F. Frommann Verlag G. Holzboog, Stuttgart-Bad Cannstatt (facsimile reprint, published in 1963, of the 1859 edition).

Speed, J., Shane, P., Nairn, I., 2002. Volcanic stratigraphy and phase chemistry of the 11,900 yr BP Waiohau eruptive episode, Tarawera Volcanic Complex, New Zealand. New Zealand Journal of Geology and Geophysics 45, 395-410.

Stephens, T., Atkin, D., Augustinus, P., Shane, P., Lorrey, A., Street-Perrott, A., Nilsson, A., Snowball, I., 2012 a. A late glacial Antarctic climate teleconnection and variable Holocene seasonality at Lake Pupuke, Auckland, New Zealand. Journal of Paleolimnology 48, 785800.

Stephens, T., Atkin, D., Cochran, U., Augustinus, P., Reid, M., Lorrey, A., Shane, P., StreetPerrott, A., 2012 b. A diatom-inferred record of reduced effective precipitation during the Last Glacial Coldest Phase (28.8-18.0 cal kyr BP) and increasing Holocene seasonality at Lake Pupuke, Auckland, New Zealand. Journal of Paleolimnology 48, 801-817.

Strelin, J.A., Denton, G.H., Vandergoes, M.J., Ninnemann, U.S., Putnam, A.E., 2011. Radiocarbon chronology of the late-glacial Puerto Bandera moraines, southern Patagonian icefield, Argentina. Quaternary Science Reviews 30, 2551-2569.

Suggate, R.P., Almond, P.C., 2005. The Last Glacial Maximum (LGM) in western South Island, New Zealand: implications for the global LGM and MIS 2. Quaternary Science Reviews 24, 1923-1940. 
Thornalley, D.J.R., McCave, I.N., Elderfield, H., 2011. Tephra in deglacial ocean sediments south of Iceland: stratigraphy, geochemistry and ocean reservoir ages. Journal of Quaternary Science 26, 190-198.

Topping, W.W., Kohn, B.P., 1973. Rhyolitic tephra marker beds in the Tongariro area, North Island, New Zealand. New Zealand Journal of Geology and Geophysics 16, 375-395.

Turney, C.S.M., McGlone, M.S., Wilmshurst, J.M., 2003. Asynchronous climate change between New Zealand and the North Atlantic during the last deglaciation. Geology 31, $223-226$.

Turney, C.S.M., Roberts, R.G., de Jonge, N., Prior, C., Wilmshurst, J.M., McGlone, M.S., Cooper, J., 2007. Redating the advance of the New Zealand Franz Josef Glacier during the Last Termination: evidence for asynchronous climate change. Quaternary Science Reviews 26, 3037-3042.

Vandergoes, M.J., Dieffenbacher-Krall, A.C., Newnham, R.M., Denton, G.H., Blaauw, M., 2008. Cooling and changing seasonality in the Southern Alps, New Zealand during the Antarctic cold reversal. Quaternary Science Reviews 27, 589-601.

Vandergoes, M.J., Hogg, A.G., Lowe, D.J., Newnham, R.M., Denton, G.H., Southon, J., Barrell, D.J.A., Blaauw, M., Wilson, C.J.N., McGlone, M.S., Allan, A.S.R., Almond, P.C., Petchey, F., Dalbell, K., Dieffenbacher-Krall, A.C., in press a. A revised age for the Kawakawa/Oruanui tephra, a key marker for the Last Glacial Maximum in New Zealand. Quaternary Science Reviews (http://dx.doi.org/10.1016/j.quascirev.2012.11.006) (online 31 Jan 2013)

Vandergoes, M.J., Newnham, R.M., Denton, G.H., Blaauw, M., Barrell, D.J., in press b. The anatomy of Last Glacial Maximum climate change in the southern mid-latitudes derived from pollen records in south Westland, New Zealand. Quaternary Science Reviews 
Vucetich, C.G., Howorth, R., 1976. Late Pleistocene tephrostratigraphy in the Taupo district, New Zealand. New Zealand Journal of Geology and Geophysics 19, 51-69.

Vucetich, C.G., Pullar, W.A., 1969. Stratigraphy and chronology of late Pleistocene volcanic ash beds in central North Island, New Zealand. New Zealand Journal of Geology and Geophysics 12, 784-837.

Vucetich, C.G., Pullar, W.A., 1973. Holocene tephra formations erupted in the Taupo area, and interbedded tephras from other sources. New Zealand Journal of Geology and Geophysics 16, 745-780.

Walker, M., Johnsen, S., Rasmussen, S.O., Popp, T., Steffensen, J.-P., Gibbard, P., Hoek, W., Lowe, J.J., Andrews, J., Björck, S., Cwynar, L., Hughen, K., Kershaw, P., Kromer, B., Litt, T., Lowe, D.J., Nakagawa, T., Newnham, R.M., Schwander, J. 2009. Formal definition and dating of the GSSP (Global Stratotype Section and Point) for the base of the Holocene using the Greenland NGRIP ice core, and selected auxiliary records. Journal of Quaternary Science 24, 3-17.

Walker, M.J.C, Björck, S., Cwynar, L.C., Fisher, D., Long, A., Lowe, J.J., Newnham, R.M., Rasmussen, S.O., 2012. Formal subdivision of the Holocene Series/Epoch: a discussion paper by a Working Group of INTIMATE (Integration of ice-core, marine and terrestrial records) and the Subcommission on Quaternary Stratigraphy (International Commission on Stratigraphy). Journal of Quaternary Science 27, 649-659.

Ward, C.M., 1995. The Lake Waikareiti landslide, Te Urewera National Park. Geological Society of New Zealand Miscellaneous Publication 81A, 184.

Wigley, G.N.A., 1990. Holocene tephrochronology and evolution of the Te Puke lowlands, Bay of Plenty, New Zealand. Unpublished MSc thesis, University of Waikato, Hamilton, New Zealand. 
Williams, P.W., King, D.N.T., Zhao, J.-X., Collerson, K.D., 2004. Speleothem master chronologies: combined Holocene ${ }^{18} \mathrm{O}$ and ${ }^{13} \mathrm{C}$ records from the North Island of New Zealand and their palaeoenvironmental interpretation. The Holocene 14, 194-208.

Williams, P.W., King, D.N.T., Zhao, J.-X., Collerson, K.D., 2005. Late Pleistocene to Holocene composite speleothem ${ }^{18} \mathrm{O}$ and ${ }^{13} \mathrm{C}$ chronologies from South Island, New Zealand-did a global Younger Dryas really exist? Earth and Planetary Science Letters 230, $301-317$.

Wilmshurst, J.M., McGlone, M.S., Leathwick, J.R., Newnham, R.M., 2007. A predeforestation pollen-climate calibration model for New Zealand and quantitative temperature reconstructions for the past18000 years. Journal of Quaternary Science 22, $535-547$.

Wilson, C.J.N., 1993. Stratigraphy, chronology, styles and dynamics of Late Quaternary eruptions from Taupo volcano, New Zealand. Philosophical Transactions of the Royal Society of London A343, 205-306.

Wilson, C.J.N., 2001. The 26.5 ka Oruanui eruption, New Zealand: an introduction and overview. Journal of Volcanology and Geothermal Research 112, 133-174.

Wilson, C.J.N., Switsur, R.V., Ward, A.P., 1988. A new ${ }^{14} \mathrm{C}$ age for the Oruanui (Wairakei) eruption, New Zealand. Geological Magazine 125, 297-300.

Wohlfarth, B., Blaauw, M., Davies, S.M., Andersson, M., Wastegård, S., Hormes, A., Posnert, G., 2006. Constraining the age of Lateglacial and early Holocene pollen zones and tephra horizons in southern Sweden with Bayesian probability methods. Journal of Quaternary Science 21, 321-334.

Zink, K.-G., Vandergoes, M.J., Mangelsdorf, K., Dieffenbacher-Krall, A.C., Schwark, L., 2010. Application of bacterial glycerol dialkyl glycerol tetraethers (GDGTs) to develop 
modern and past temperature estimates from New Zealand lakes. Organic Geochemistry 41, 1060-1066. 


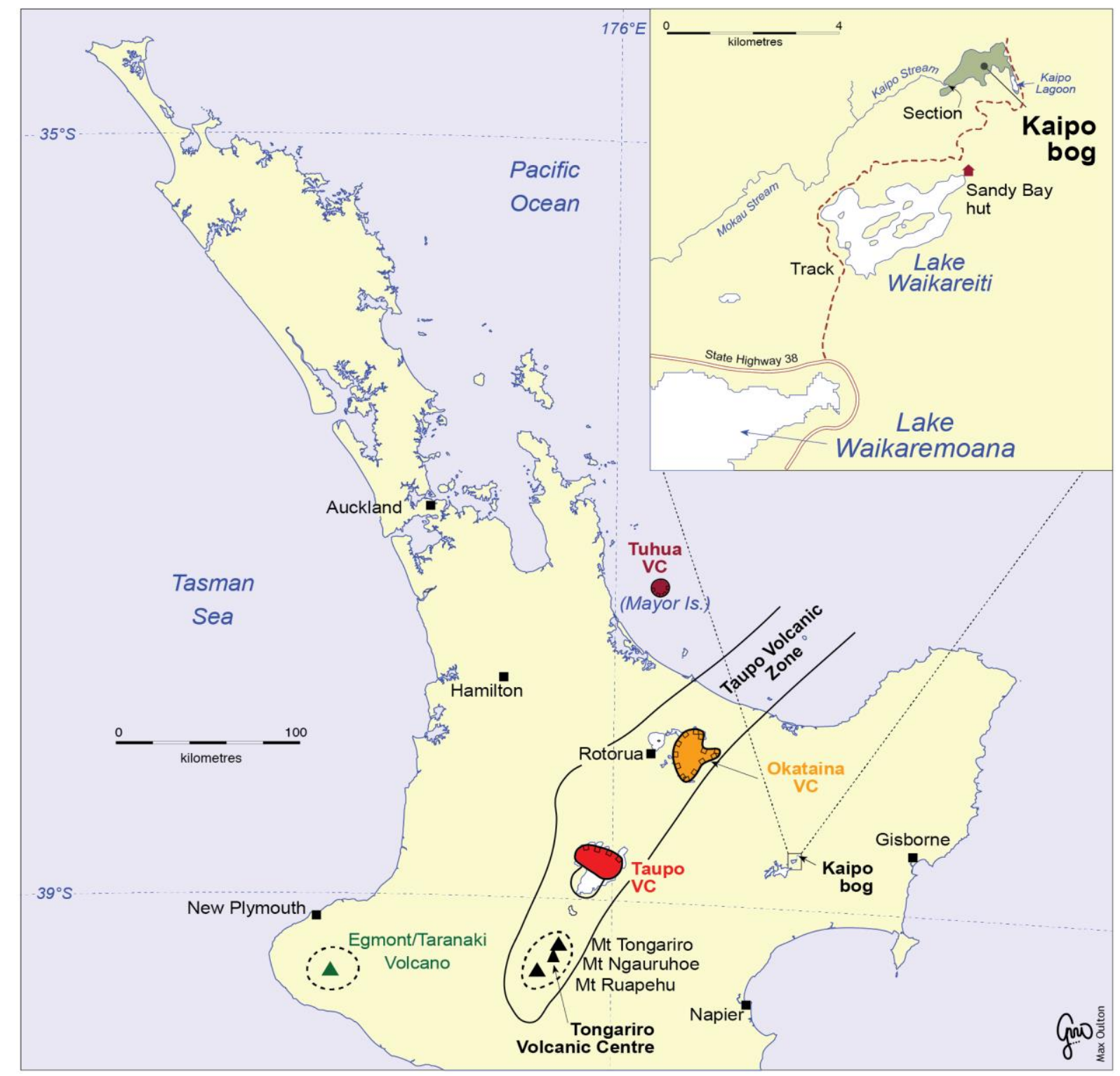

Fig. 1. Map of central and northern North Island, New Zealand, showing source volcanoes of the 24 tephras dated in this paper (after Froggatt and Lowe, 1990). VC, Volcanic Centre. Inset shows locations of Kaipo bog and the tephra-peat section. 


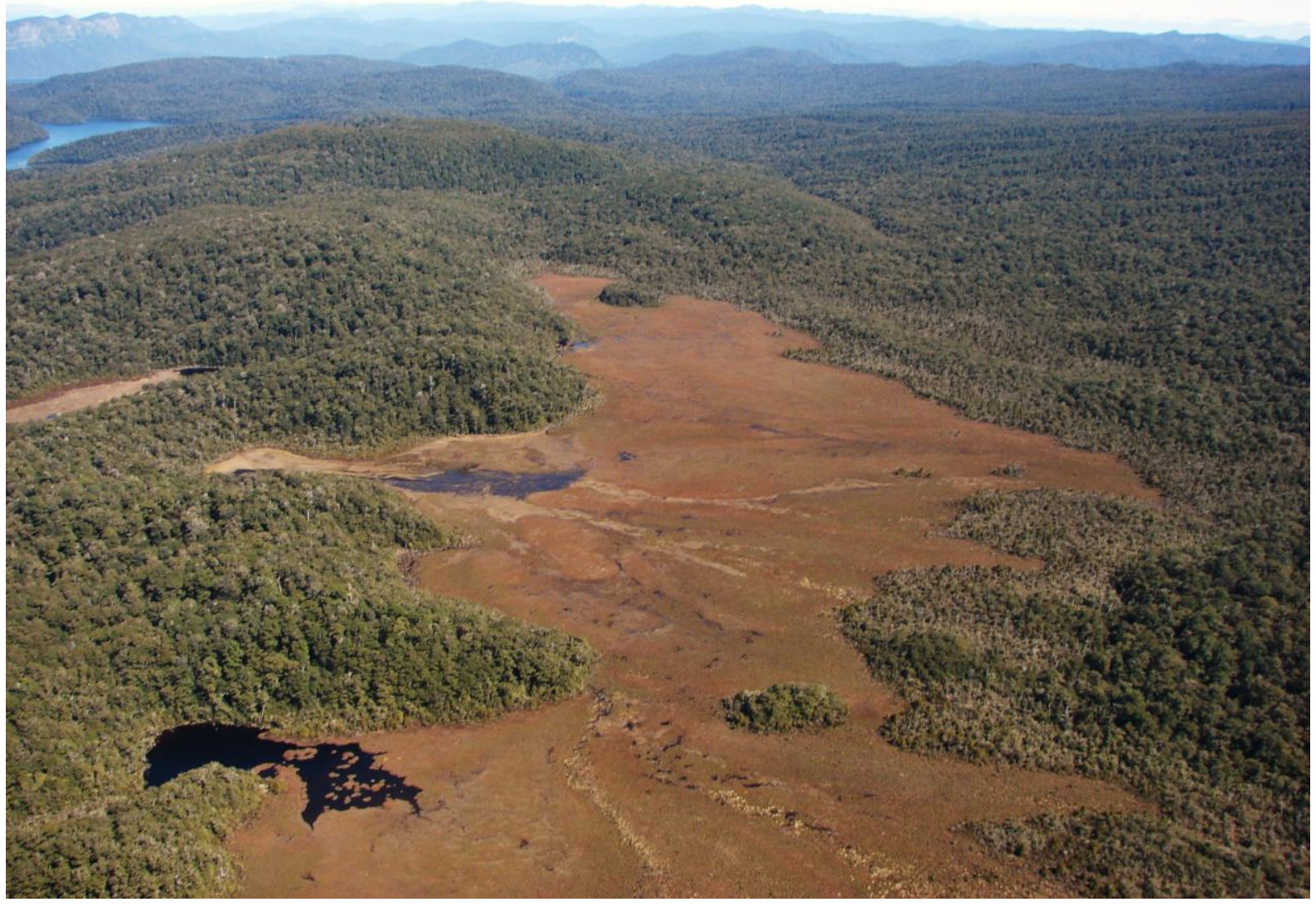

Fig. 2. Aerial photograph of Kaipo bog, viewed looking south-westward, in Te Urewera National Park. Western arm of Lake Waikareiti is visible at upper left. The tephra-peat section, at ca. $980 \mathrm{~m}$ elevation, is exposed just within the small salient of beech forest visible at the far end of the bog, beyond which the Kaipo Stream drains towards the right initially and then into the narrow valley in upper-middle distance that marks the base of the gentlysloping slip surface (at right) of the Waikareiti landslide (Ward, 1995; Beetham et al., 2002; Leonard et al., 2010). Photo courtesy of Chris Ward, New Zealand Department of Conservation (photographed in September 2007). 


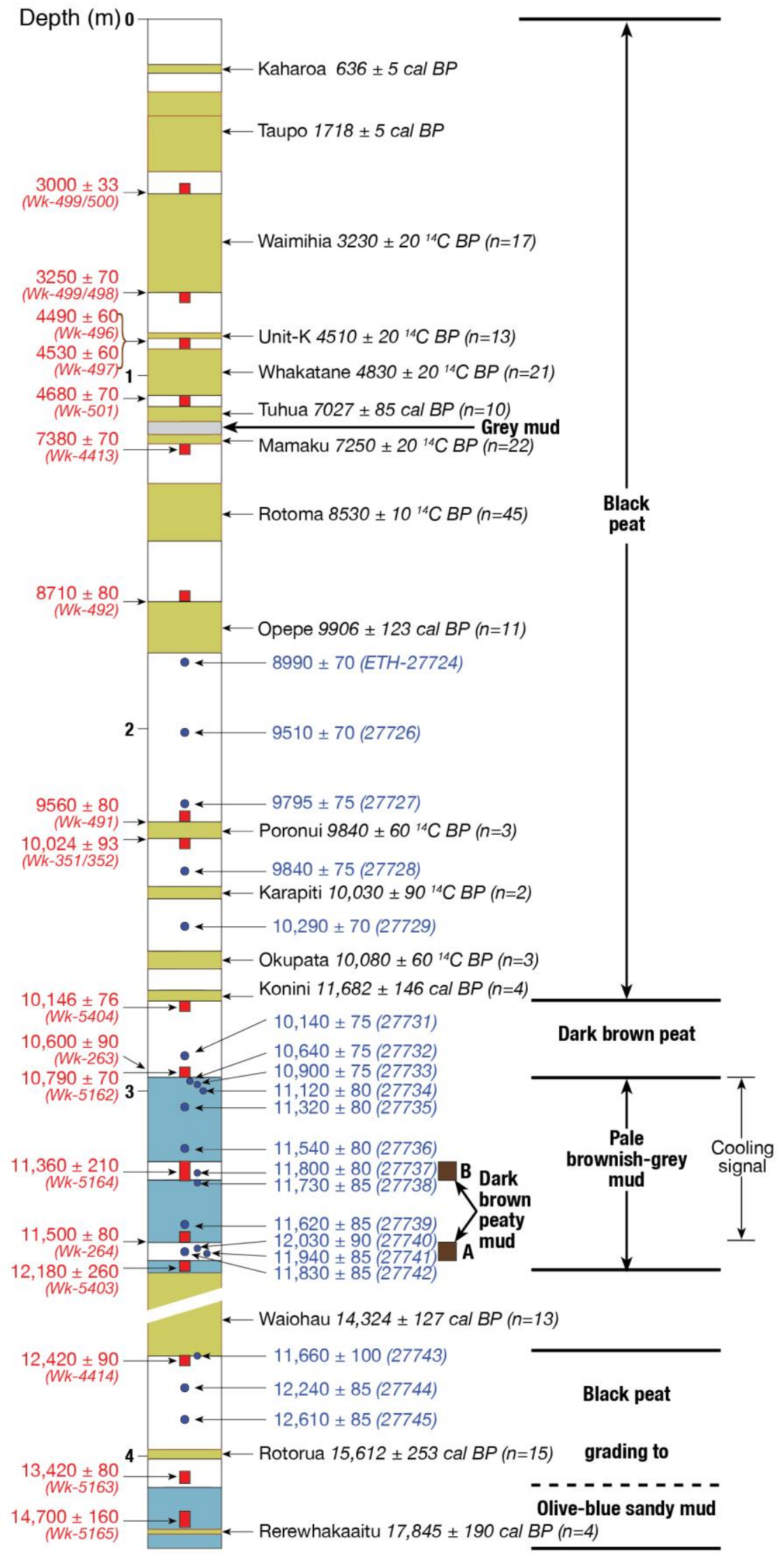

Fig. 3 caption below 
Fig. 3. Stratigraphy and chronology (in ${ }^{14} \mathrm{C}$ yr BP except where marked as cal. yr BP) of the Kaipo bog sequence at $38^{\circ} 40^{\prime} 56^{\prime \prime} \mathrm{S}$ and $177^{\circ} 11^{\prime}$ 00" E (after Lowe et al., 1999; Newnham and Lowe, 2000, 2001; Shane et al., 2003). These ages, all reported at $\pm 1 \sigma$, form the underlying basis of the new Bayesian age models developed in this paper. Radiometric ${ }^{14} \mathrm{C}$ ages at left (in red, Waikato dating laboratory) are from Lowe and Hogg (1986) and Lowe et al. (1999); AMS ${ }^{14} \mathrm{C}$ ages at right (in blue, ETH dating laboratory) are from Hajdas et al. (2006). Mean ages for the tephras (in black) are in ${ }^{14} \mathrm{C}$ yr BP or cal. yr BP $( \pm 1 \sigma)$ as indicated. Sources for tephra age data are (i) Kaharoa, Taupo: Hogg et al. (2003, 2012); (ii) Waimihia, Unit-K, Whakatane, Mamaku, Rotoma, Poronui, Karapiti, Okupata: Hajdas et al. (2006); (iii) Tuhua, Opepe, Konini, Waiohau, Rotorua, Rerewhakaaitu: Tables 2 and 3. Names and volcanic sources of the 16 tephras are given in Table 1. (For interpretation of the references to colour in this and other figure legends, the reader is referred to the web version of this article.) 

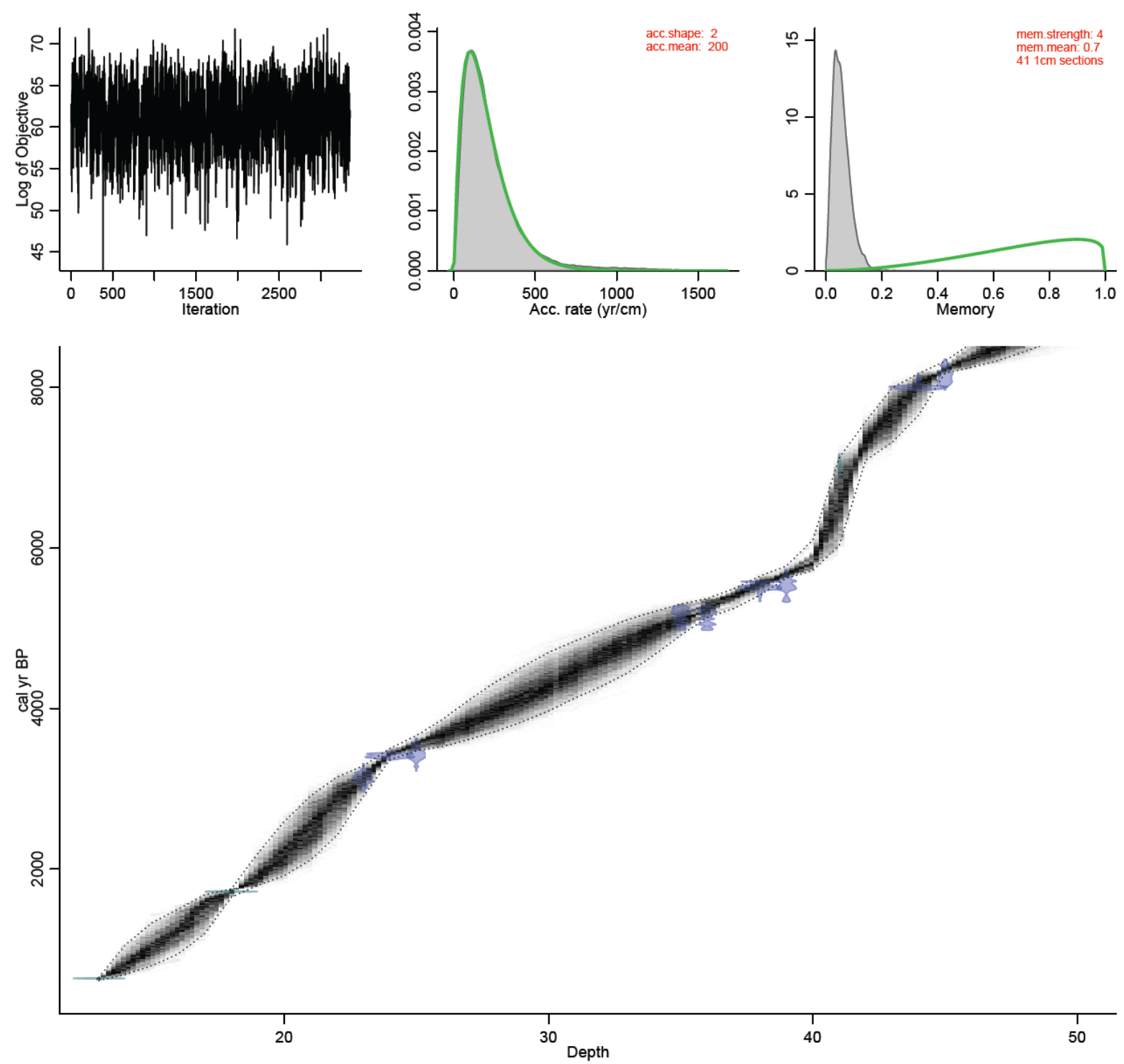

Fig. 4. Posterior age-depth models (in grey) derived using Bacon age-depth modelling and IntCal09 for the upper segment (0-50 cm depth, tephra-free basis) of the Kaipo bog sequence. Calibrated distributions of the individual dates are shown in blue or green, and the grey dots indicate the $95 \%$ probability intervals. The inset graphs at the top show (left) the number of MCMC iterations used to generate the grey-scale graphs, (centre) the prior (green) and posterior (grey) distributions of accumulation rates, and (right) memory $\mathrm{R}$ for the Kaipo modelling. The complete set of ages (in ${ }^{14} \mathrm{C}$ yr BP or cal. $\mathrm{yr} \mathrm{BP}, \pm 1 \sigma$ ) and associated sampling depths (tephra-free basis) of the Kaipo bog sequence, as modified for this paper, are given in Table S1. (For interpretation of the references to colour in this and other figure legends, the reader is referred to the web version of this article.) 

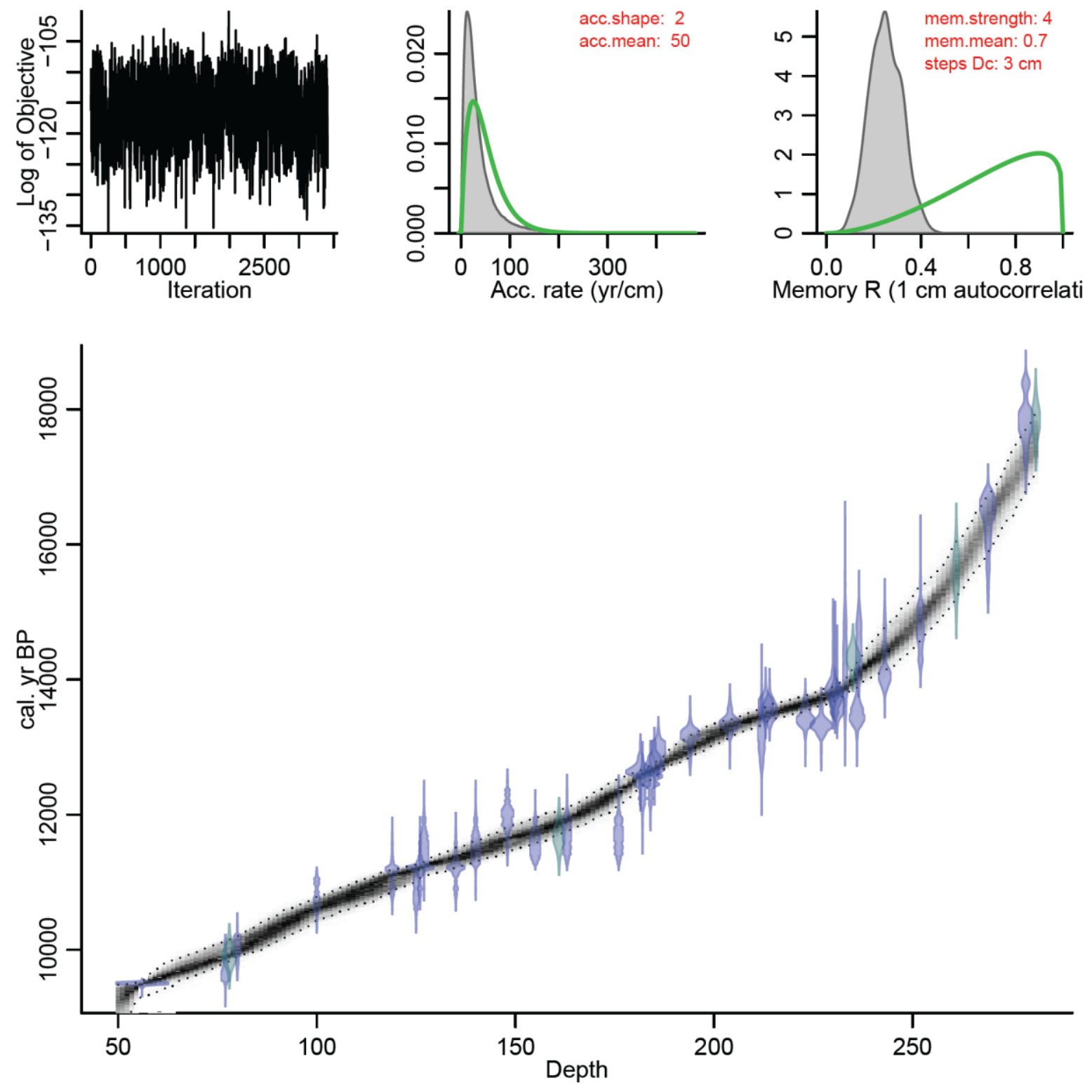

Fig. 5. Posterior age-depth models (in grey) derived using Bacon age-depth modelling and IntCal09 for the lower segment (50-281 cm depth, tephra-free basis) of the Kaipo bog sequence. Calibrated distributions of the individual dates are shown in blue or green, and the grey dots indicate the $95 \%$ probability intervals. Other details as for Fig. 4. (For interpretation of the references to colour in this and other figure legends, the reader is referred to the web version of this article.) 


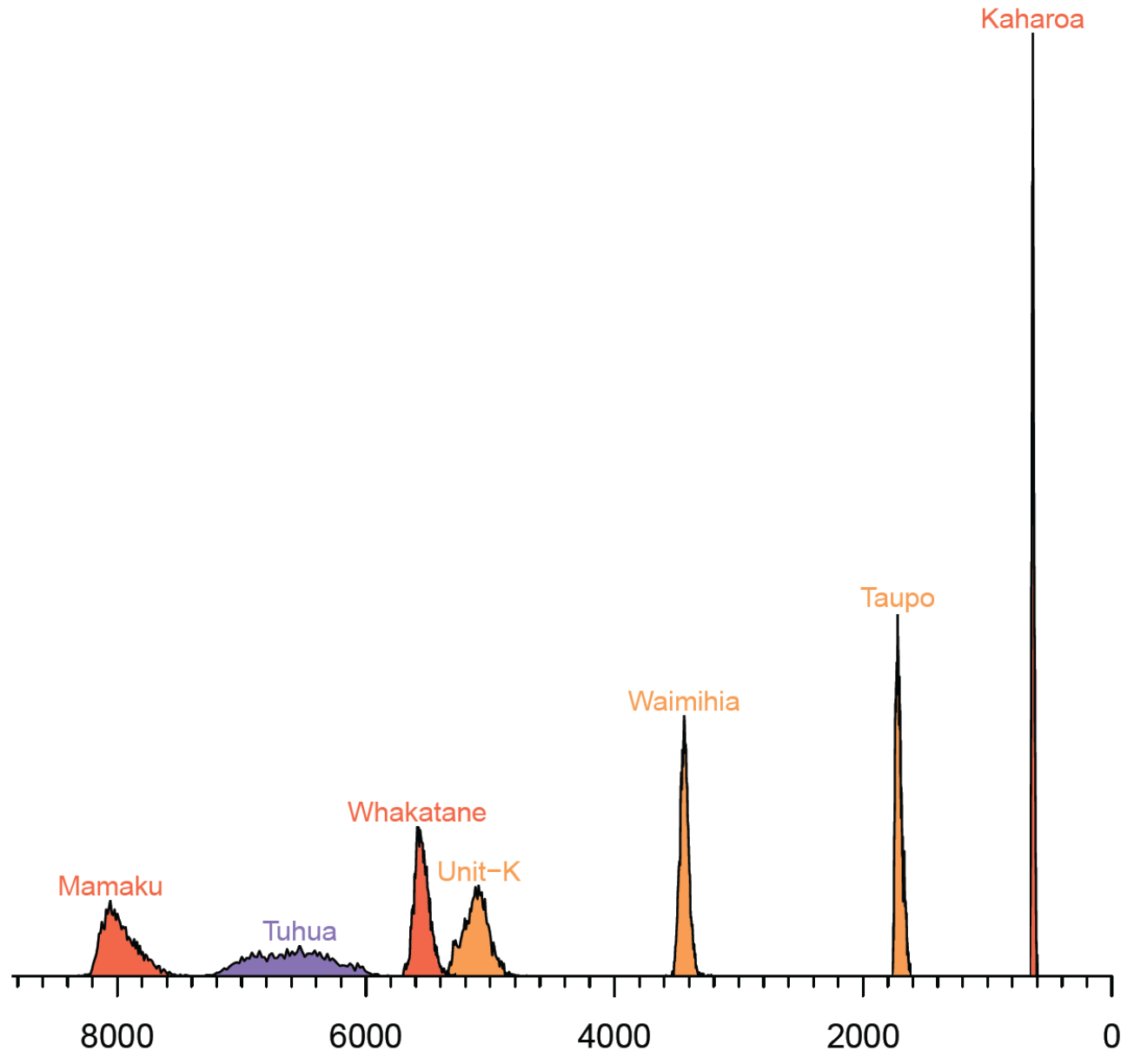

cal. yr BP

Fig. 6. Bacon-derived age models for seven Holocene tephras in the upper segment of the Kaipo bog sequence. Plots are coloured according to tephra source volcanoes: red, Okataina; orange, Taupo; violet, Tuhua/Mayor Island (Table 1). (For interpretation of the references to colour in this and other figure legends, the reader is referred to the web version of this article.) 


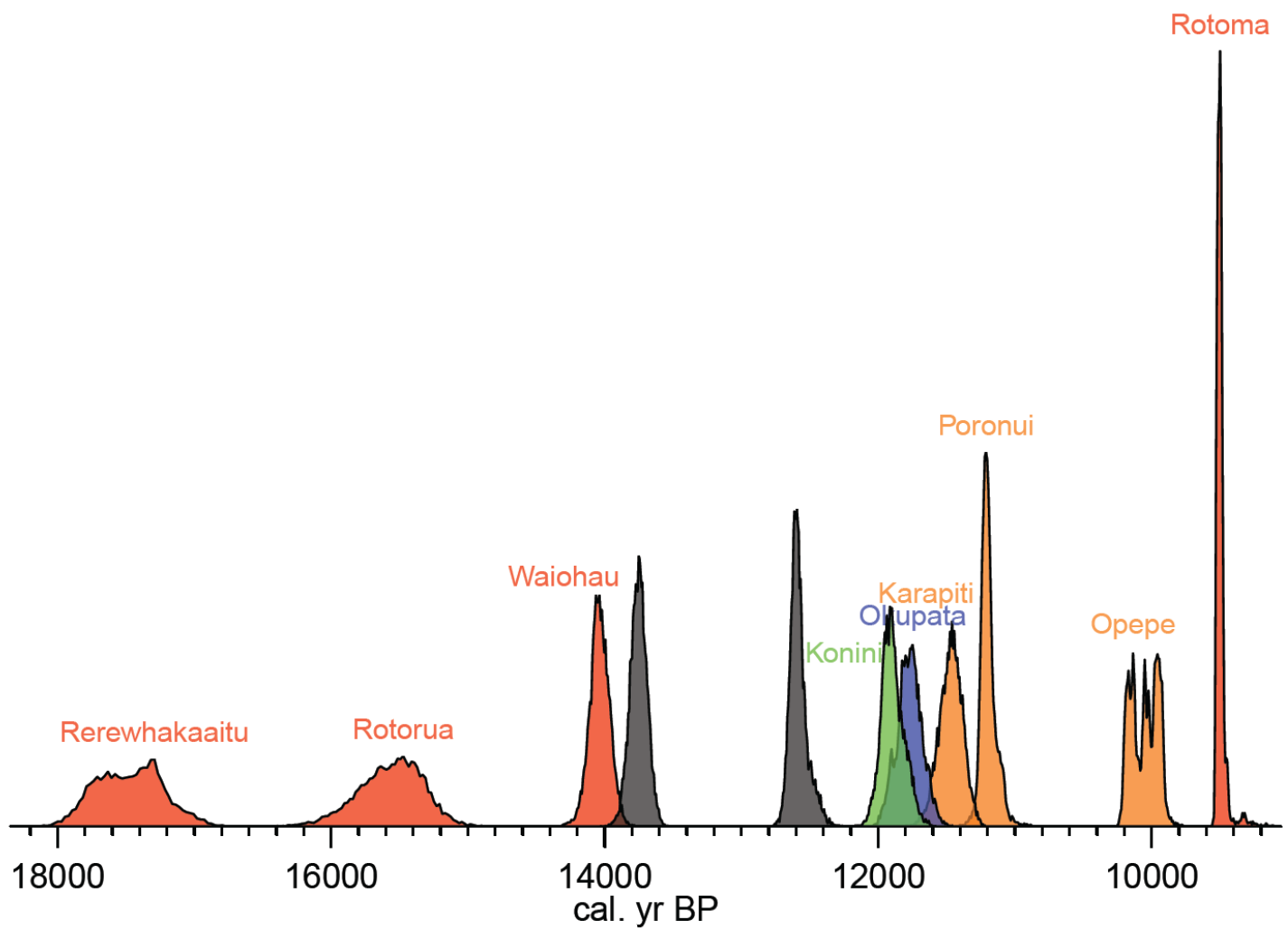

Fig. 7. Bacon-derived age models for nine Holocene or Lateglacial tephras in the lower segment of the Kaipo bog sequence. Plots are coloured according to tephra source volcanoes: red, Okataina; orange, Taupo; green, Egmont/Taranaki; blue, Tongariro (Table 1). Grey plots show the Bacon-derived start and end ages of the Lateglacial cool episode (i.e., NZce-3) between the Waiohau and Konini tephras. (For interpretation of the references to colour in this and other figure legends, the reader is referred to the web version of this article.) 


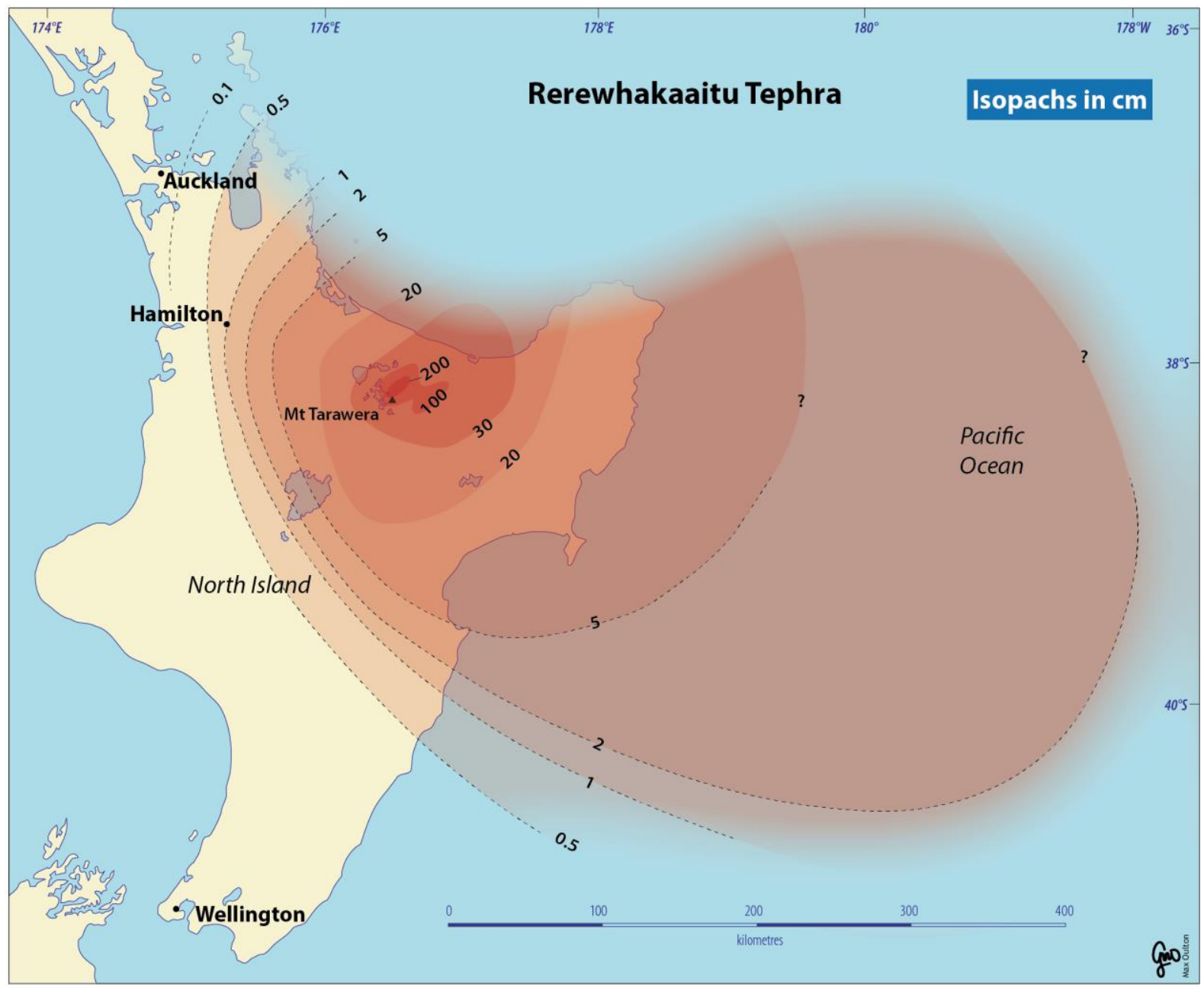

Fig. 8. Isopach map in centimetres showing the distribution of the Rerewhakaaitu tephra (aged ca. 17,496 \pm 462 cal. yr BP). Based mainly on Newnham et al. (2003) together with data from Darragh et al. (2006), Shane et al. (2006), Carter et al. (1995, 2008), and references cited in D.J. Lowe et al. (2008, p. 98). 


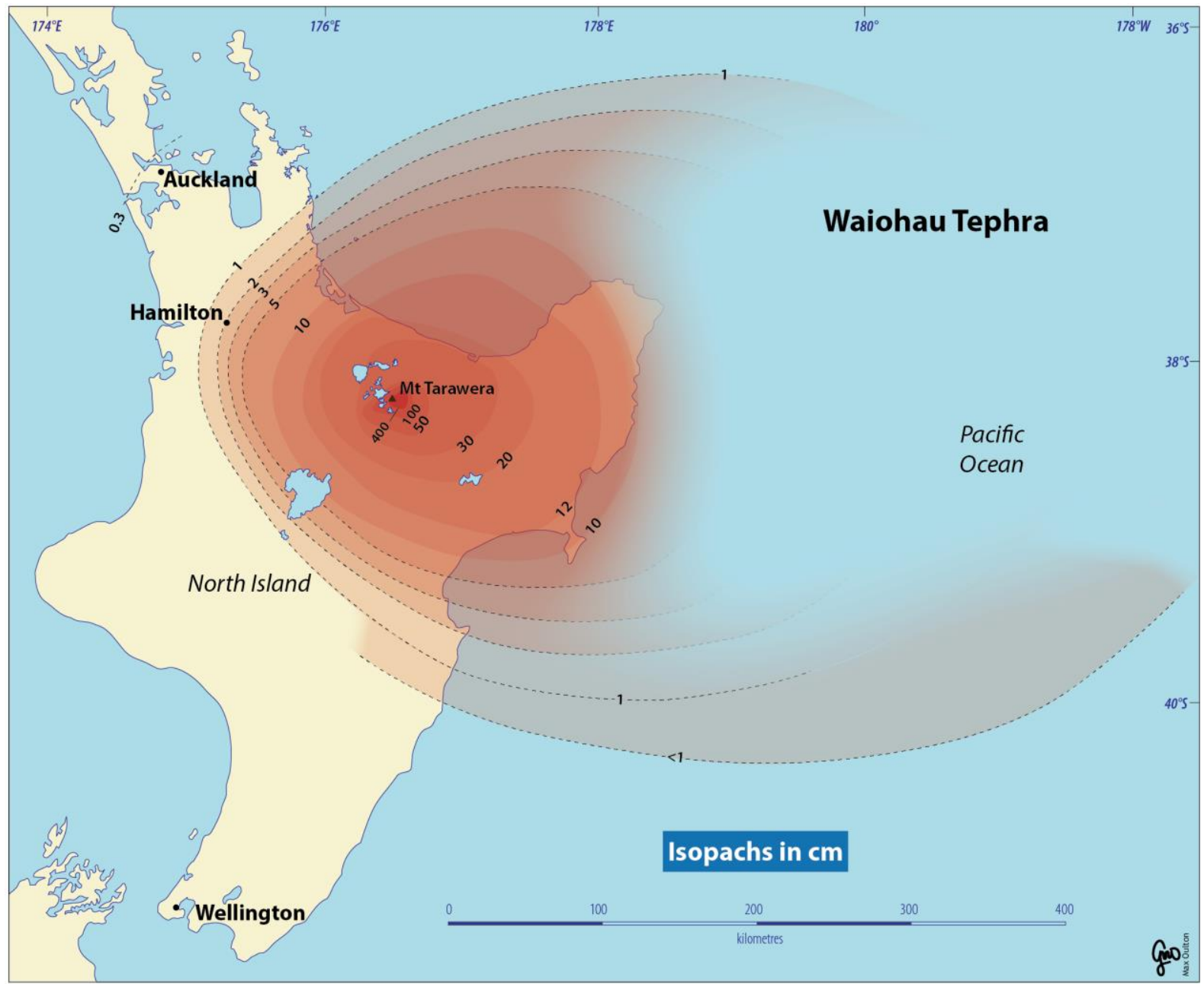

Fig. 9. Isopach map in centimetres showing the distribution of the Waiohau tephra (aged ca. $14,009 \pm 155$ cal. yr BP). Based mainly on Pullar (1973) together with data from Speed et al. (2002), Shane et al. (2006), Carter et al. (2008), and references cited in D.J. Lowe et al. (2008, p. 98). 


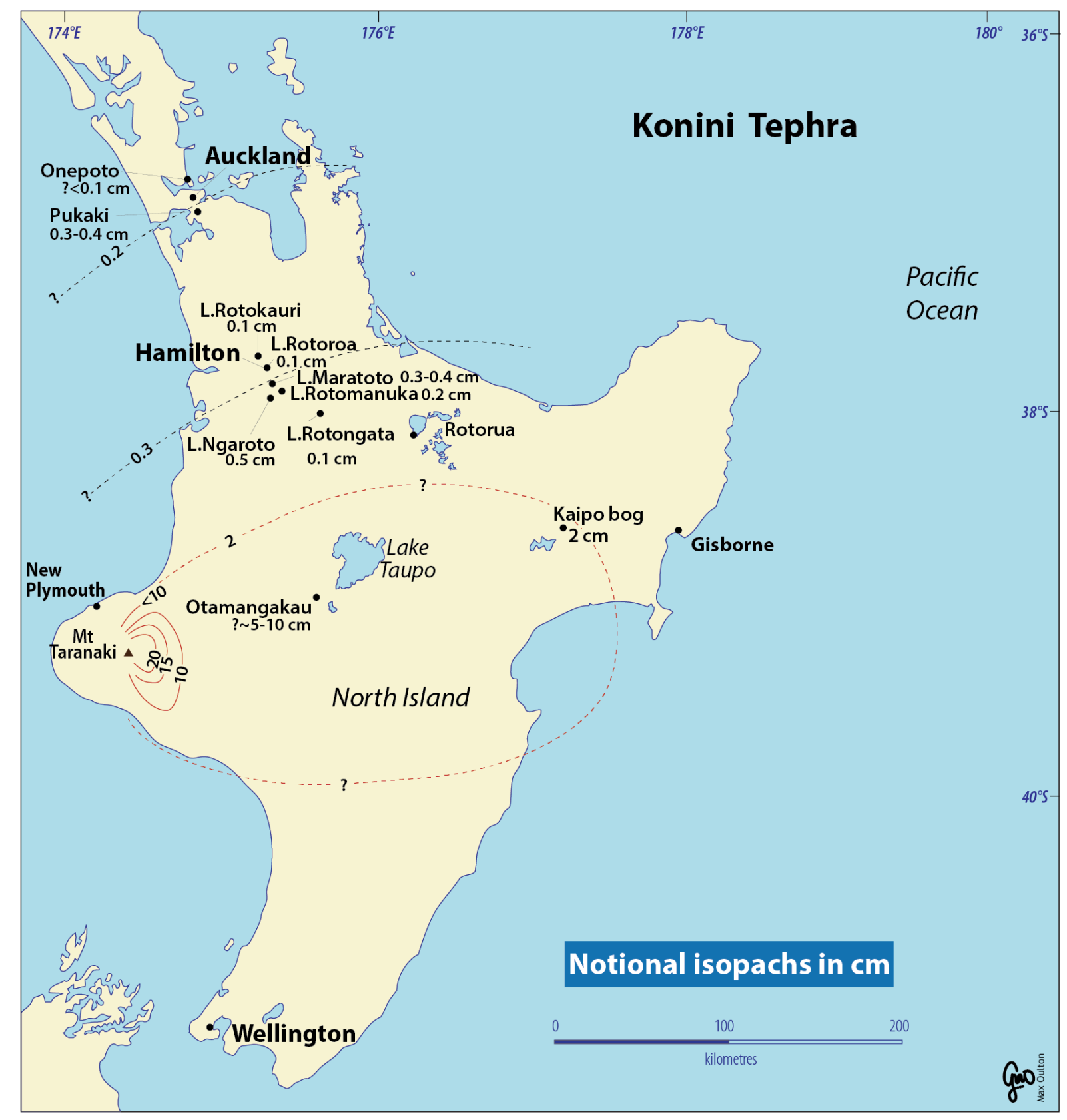

Fig. 10. Isopach map in centimetres showing the general distribution of the Konini tephra (bed b), aged ca. 11,880 \pm 183 cal. yr BP. The sparseness of data means that the distal isopach lines are notional or indicative only. Proximal isopachs are from Alloway et al. (1995) and comprise both beds a and b of Konini tephra; distal occurrences of bed b are from Lowe (1988), McGlone and Neall (1994), Lowe et al. (1999), Sandiford et al. (2001), Shane and Hoverd (2002), Shane (2005), and references in D.J. Lowe et al. (2008, p. 98). 
Start

13,864-13,614 cal. yr BP

Mid 13,739 \pm 125 cal. yr BP

(Mean 13,745 cal. yr BP)
End

12,690-12,410 cal. yr BP

Mid $12,550 \pm 140$ cal. yr BP

(Mean 12,578 cal. yr BP)
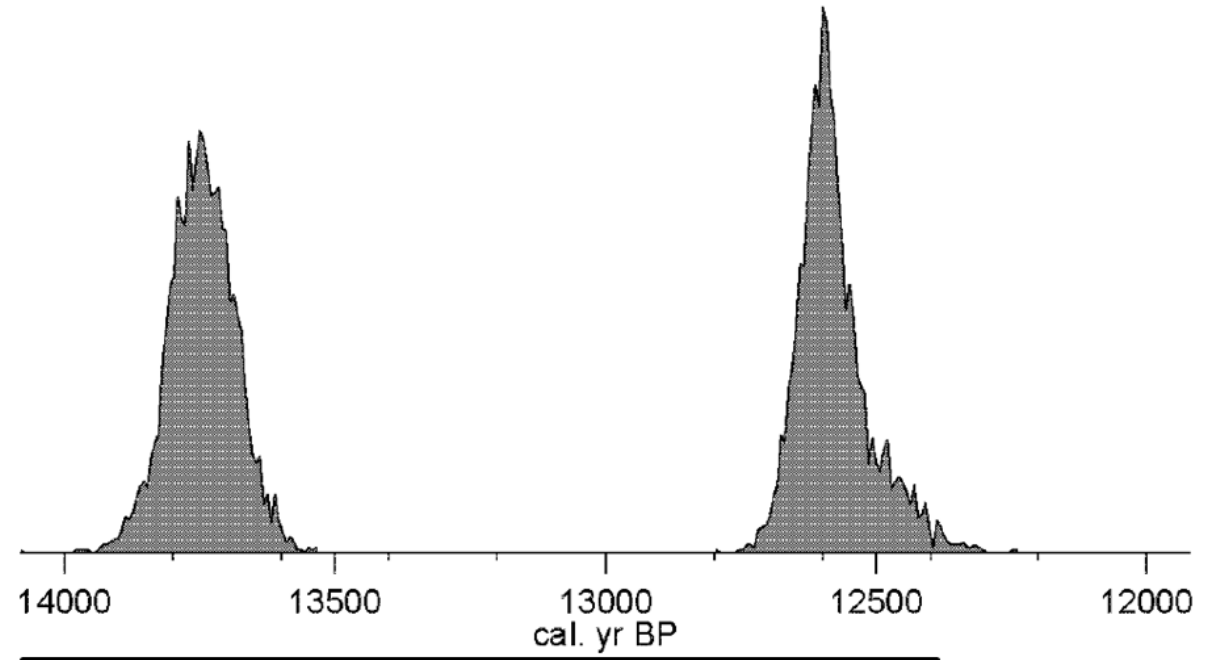

Antarctic Cold Reversal

Younger Dryas (GS-1)

Fig. 11. Bayesian age model derived using Bacon and IntCal09 for the timing of the start and end of the Lateglacial reversal (LGR), now referred to as the Lateglacial cool episode (climate event NZce-3 in the NZ-CES). Calendar age ranges are the extremes of the highest posterior density (HPD) regions set at $95 \%$ probability. Ages are also reported as mid-points ('Mid') of the HPD regions (95\% confidence intervals), and as error-weighted mean ages ('Mean') attained during modelling (the latter are single-age representations that take into account the general outcome of all MCMC iterations in the Bacon modelling). In comparison, mean ages $( \pm 2 \sigma)$ obtained using OxCal's $P \_$Sequence modelling for the Lateglacial cool episode are 13,732 \pm 76 cal. yr BP (onset) and 12,575 \pm 57 cal. yr BP (ending). Onsets and endings of the ACR event (after Carter et al., 2008; Bostock et al., in press) and the GS-1/YD event (after Blockley et al., 2012) are shown also. 


\section{Table 1}

Age models (95\% probabilities) for 24 marker tephras erupted since ca. 30,000 cal. yr BP in New Zealand (listed in stratigraphic order)

\begin{tabular}{|c|c|c|c|c|c|}
\hline $\begin{array}{l}\text { Tephra name } \\
\text { (source) }^{a}\end{array}$ & $\begin{array}{c}\text { Calibrated } \\
95 \% \text { date } \\
\text { (AD) or age } \\
\text { range } \\
\text { (cal. yr BP) }\end{array}$ & $\begin{array}{c}\text { Mid-point } \\
\text { (mid) }{ }^{b} \text { or } \\
\text { mean }^{\text {b }} \text { age or } \\
\text { WMA }^{c} \text { of } 95 \% \\
\text { confidence } \\
\text { intervals (cal. } \\
\text { yr BP) }\end{array}$ & $\begin{array}{c}\text { Basis of age } \\
\text { determination }^{d}\end{array}$ & References & Comments \\
\hline \multirow[t]{3}{*}{$\begin{array}{l}\text { Kaharoa } \\
\text { (OK) }\end{array}$} & $\begin{array}{l}\text { AD 1305- } \\
1325\end{array}$ & $\begin{array}{l}636 \pm 12 \\
\text { mean }\end{array}$ & ${ }^{14} \mathrm{C}$ wiggle match on log & $\begin{array}{l}\text { Hogg et al. (2003); } \\
\text { see also Buck et al. } \\
(2003)\end{array}$ & $\begin{array}{l}\text { Calendar date AD } \\
1314 \pm 12 \text { (winter) }\end{array}$ \\
\hline & $611-650$ & $\begin{array}{l}631 \pm 19 \text { mid } \\
633 \mathrm{WMA}\end{array}$ & $\begin{array}{l}\text { Bacon modelling of } \\
\text { modified Kaipo peat } \\
\text { sequence against } \\
\text { IntCal09 }\end{array}$ & $\begin{array}{l}\text { Hajdas et al. (2006), } \\
\text { Table S1 }\end{array}$ & \\
\hline & $624-648$ & $\begin{array}{l}636 \pm 12 \\
\text { mean }\end{array}$ & $\begin{array}{l}\text { P_Sequence modelling (k } \\
=10 \text { ) of modified Kaipo } \\
\text { peat sequence against } \\
\text { IntCal09 }\end{array}$ & $\begin{array}{l}\text { Hajdas et al. (2006), } \\
\text { Table S1, Fig. S1 }\end{array}$ & \\
\hline \multirow[t]{3}{*}{$\begin{array}{l}\text { Taupo (Unit } \\
\text { Y) (TP) }\end{array}$} & AD 224-240 & $\begin{array}{l}1718 \pm 10 \\
\text { mean }\end{array}$ & ${ }^{14} \mathrm{C}$ wiggle match on log & Hogg et al. (2012) & $\begin{array}{l}\text { Calendar date AD } \\
232 \pm 10 \text { (late } \\
\text { summer-early } \\
\text { autumn) } \\
\end{array}$ \\
\hline & 1648-1750 & $\begin{array}{l}1699 \pm 51 \\
\text { mid } \\
1710 \text { WMA }\end{array}$ & $\begin{array}{l}\text { Bacon modelling of } \\
\text { modified Kaipo peat } \\
\text { sequence against } \\
\text { IntCal09 }\end{array}$ & $\begin{array}{l}\text { Hajdas et al. (2006), } \\
\text { Table S1 }\end{array}$ & \\
\hline & 1707-1731 & $\begin{array}{l}1719 \pm 12 \\
\text { mean }\end{array}$ & $\begin{array}{l}\text { P_Sequence modelling (k } \\
=10 \text { ) of modified Kaipo } \\
\text { peat sequence against } \\
\text { IntCal09 }\end{array}$ & $\begin{array}{l}\text { Hajdas et al. (2006), } \\
\text { Table S1, Fig. S1 }\end{array}$ & \\
\hline $\begin{array}{l}\text { Mapara (Unit } \\
\text { X) (TP) }\end{array}$ & $\begin{array}{l}1941-2155 \\
(95.4 \%)\end{array}$ & $\begin{array}{l}2059 \pm 118 \\
\text { mean }\end{array}$ & $\begin{array}{l}\text { Calibration of } 7{ }^{14} \mathrm{C} \text { ages } \\
\text { against SHCal04 via } \\
\text { Tau_Boundary }\end{array}$ & Table 2 & \\
\hline $\begin{array}{l}\text { Whakaipo } \\
\text { (Unit V) (TP) }\end{array}$ & $\begin{array}{l}2749-2862 \\
(95.4 \%)\end{array}$ & $\begin{array}{l}2800 \pm 60 \\
\text { mean }\end{array}$ & $\begin{array}{l}\text { Calibration of } 12{ }^{14} \mathrm{C} \\
\text { ages against } \mathrm{SHCal04} \text { via } \\
\text { Tau_Boundary }\end{array}$ & Table 2 & \\
\hline \multirow[t]{2}{*}{$\begin{array}{l}\text { Waimihia } \\
\text { (Unit S) } \\
\text { (TP) }\end{array}$} & $3294-3509$ & $\begin{array}{l}3401 \pm 108 \\
\text { mid } \\
3421 \text { WMA }\end{array}$ & $\begin{array}{l}\text { Bacon modelling of } \\
\text { modified Kaipo peat } \\
\text { sequence against } \\
\text { IntCal09 }\end{array}$ & $\begin{array}{l}\text { Hajdas et al. (2006), } \\
\text { Table S1 }\end{array}$ & \\
\hline & $3332-3431$ & $\begin{array}{l}3382 \pm 50 \\
\text { mean }\end{array}$ & $\begin{array}{l}\text { P_Sequence modelling (k } \\
=10) \text { of modified Kaipo } \\
\text { peat sequence against } \\
\text { IntCal09 }\end{array}$ & $\begin{array}{l}\text { Hajdas et al. (2006), } \\
\text { Table S1, Fig. S1 }\end{array}$ & \\
\hline $\begin{array}{l}\text { Stent (Unit Q) } \\
\text { (TP) }\end{array}$ & $\begin{array}{l}4224-4418 \\
(93.9 \%) \\
4185-4200 \\
(1.5 \%)\end{array}$ & $\begin{array}{l}4322 \pm 112 \\
\text { mean }\end{array}$ & $\begin{array}{l}\text { Calibration of } 7{ }^{14} \mathrm{C} \text { ages } \\
\text { against SHCal04 via } \\
\text { Tau_Boundary }\end{array}$ & Table 2 & \\
\hline
\end{tabular}




\begin{tabular}{|c|c|c|c|c|}
\hline \multirow[t]{2}{*}{$\begin{array}{l}\text { Unit K } \\
\text { (TP) }\end{array}$} & $4901-5321$ & $\begin{array}{l}5111 \pm 210 \\
\text { mid } \\
5104 \mathrm{WMA}\end{array}$ & $\begin{array}{l}\text { Bacon modelling of } \\
\text { modified Kaipo peat } \\
\text { sequence against } \\
\text { IntCalo9 }\end{array}$ & $\begin{array}{l}\text { Hajdas et al. } \\
\text { (2006), Table S1 }\end{array}$ \\
\hline & $5015-5160$ & $\begin{array}{l}5088 \pm 73 \\
\text { mean }\end{array}$ & $\begin{array}{l}\text { P_Sequence modelling } \\
(\mathrm{K}=10) \text { of modified } \\
\text { Kaipo peat sequence } \\
\text { against IntCalog }\end{array}$ & $\begin{array}{l}\text { Hajdas et al. } \\
\text { (2006), Table S1, } \\
\text { Fig. S1 }\end{array}$ \\
\hline \multirow[t]{2}{*}{$\begin{array}{l}\text { Whakatane } \\
\text { (OK) }\end{array}$} & $5381-5671$ & $\begin{array}{l}5526 \pm 145 \\
\text { mid } \\
5536 \text { WMA }\end{array}$ & $\begin{array}{l}\text { Bacon modelling of } \\
\text { modified Kaipo peat } \\
\text { sequence against } \\
\text { IntCal09 }\end{array}$ & $\begin{array}{l}\text { Hajdas et al. } \\
\text { (2006), Table S1 }\end{array}$ \\
\hline & 5494-5589 & $\begin{array}{l}5542 \pm 48 \\
\text { mean }\end{array}$ & $\begin{array}{l}\text { P_Sequence modelling } \\
(\mathrm{k}=10) \text { of modified } \\
\text { Kaipo peat sequence } \\
\text { against IntCal09 }\end{array}$ & $\begin{array}{l}\text { Hajdas et al. } \\
\text { (2006), Table S1, } \\
\text { Fig. S1 }\end{array}$ \\
\hline \multirow[t]{3}{*}{$\begin{array}{l}\text { Tuhua } \\
\text { (TU) }\end{array}$} & $6029-7124$ & $\begin{array}{l}6577 \pm 547 \\
\text { mid } \\
6609 \text { WMA }\end{array}$ & $\begin{array}{l}\text { Bacon modelling of } \\
\text { modified Kaipo peat } \\
\text { sequence against } \\
\text { IntCal09 }\end{array}$ & $\begin{array}{l}\text { Hajdas et al. } \\
\text { (2006), Table S1 }\end{array}$ \\
\hline & 6797-7097 & $\begin{array}{l}6947 \pm 150 \\
\text { mean }\end{array}$ & $\begin{array}{l}\text { P_Sequence modelling } \\
(\mathrm{k}=10) \text { of modified } \\
\text { Kaipo peat sequence } \\
\text { against IntCal09 }\end{array}$ & $\begin{array}{l}\text { Hajdas et al. } \\
\text { (2006), Table S1, } \\
\text { Fig. S1 }\end{array}$ \\
\hline & $\begin{array}{l}6868-7206 \\
(95.4 \%)\end{array}$ & $\begin{array}{l}7027 \pm 170 \\
\text { mean }\end{array}$ & $\begin{array}{l}\text { Calibration of } 10^{14} \mathrm{C} \\
\text { ages against } \mathrm{SHCal04} \\
\text { via Tau Boundary }\end{array}$ & Table 2 \\
\hline \multirow[t]{2}{*}{$\begin{array}{l}\text { Mamaku } \\
\text { (OK) }\end{array}$} & $7682-8197$ & $\begin{array}{l}7940 \pm 257 \\
\text { mid } \\
7979 \text { WMA }\end{array}$ & $\begin{array}{l}\text { Bacon modelling of } \\
\text { modified Kaipo peat } \\
\text { sequence against } \\
\text { IntCal09 }\end{array}$ & $\begin{array}{l}\text { Hajdas et al. } \\
\text { (2006), Table S1 }\end{array}$ \\
\hline & $7934-8050$ & $\begin{array}{l}7992 \pm 58 \\
\text { mean }\end{array}$ & $\begin{array}{l}\text { P_Sequence modelling } \\
(\mathrm{k}=10) \text { of modified } \\
\text { Kaipo peat sequence } \\
\text { against IntCal09 }\end{array}$ & $\begin{array}{l}\text { Hajdas et al. } \\
\text { (2006), Table S1, } \\
\text { Fig. S1 }\end{array}$ \\
\hline \multirow[t]{2}{*}{$\begin{array}{l}\text { Rotoma } \\
\text { (OK) }\end{array}$} & 9303-9543 & $\begin{array}{l}9423 \pm 120 \\
\text { mid } \\
9482 W M A\end{array}$ & $\begin{array}{l}\text { Bacon modelling of } \\
\text { modified Kaipo peat } \\
\text { sequence against } \\
\text { IntCal09 }\end{array}$ & $\begin{array}{l}\text { Hajdas et al. } \\
\text { (2006), Table S1 }\end{array}$ \\
\hline & $9432-9512$ & $\begin{array}{l}9472 \pm 40 \\
\text { mean }\end{array}$ & $\begin{array}{l}\text { P_Sequence modelling } \\
(\mathrm{k}=2) \text { of modified } \\
\text { Kaipo peat sequence } \\
\text { against IntCal09 }\end{array}$ & $\begin{array}{l}\text { Hajdas et al. } \\
\text { (2006), Table S1, } \\
\text { Fig. S2 }\end{array}$ \\
\hline \multirow[t]{3}{*}{$\begin{array}{l}\text { Opepe (Unit E) } \\
\text { (TP) }\end{array}$} & $9831-10,151$ & $\begin{array}{l}9991 \pm 160 \\
\text { mid } \\
9971 \text { WMA }\end{array}$ & $\begin{array}{l}\text { Bacon modelling of } \\
\text { modified Kaipo peat } \\
\text { sequence against } \\
\text { IntCal09 }\end{array}$ & $\begin{array}{l}\text { Hajdas et al. } \\
\text { (2006), Table S1 }\end{array}$ \\
\hline & $9881-10,126$ & $\begin{array}{l}10,004 \pm 122 \\
\text { mean }\end{array}$ & $\begin{array}{l}\text { P_Sequence modelling } \\
(\mathrm{k}=2) \text { of modified } \\
\text { Kaipo peat sequence } \\
\text { against IntCal09 }\end{array}$ & $\begin{array}{l}\text { Hajdas et al. } \\
\text { (2006), Table S1, } \\
\text { Fig. S2 }\end{array}$ \\
\hline & $\begin{array}{l}9682-10,140 \\
(95.4 \%)\end{array}$ & $\begin{array}{l}9906 \pm 246 \\
\text { mean }\end{array}$ & $\begin{array}{l}\text { Calibration of } 11^{14} \mathrm{C} \\
\text { ages against SHCal04 } \\
\text { via Tau_Boundary }\end{array}$ & Table 2 \\
\hline
\end{tabular}




\begin{tabular}{|c|c|c|c|c|c|}
\hline \multirow[t]{2}{*}{$\begin{array}{l}\text { Poronui (Unit } \\
\text { C) } \\
\text { (TP) }\end{array}$} & $11,055-11,285$ & $\begin{array}{l}11,170 \pm 115 \\
\text { mid } \\
11,184 \\
\text { WMA }\end{array}$ & $\begin{array}{l}\text { Bacon modelling of } \\
\text { modified Kaipo peat } \\
\text { sequence against } \\
\text { IntCal09 }\end{array}$ & $\begin{array}{l}\text { Hajdas et al. } \\
\text { (2006), Table S1 }\end{array}$ & \\
\hline & $11,143-11,246$ & $\begin{array}{l}11,195 \pm 51 \\
\text { mean }\end{array}$ & $\begin{array}{l}\text { P_Sequence modelling } \\
(\mathrm{k}=2) \text { of modified } \\
\text { Kaipo peat sequence } \\
\text { against IntCal09 }\end{array}$ & $\begin{array}{l}\text { Hajdas et al. } \\
\text { (2006), Table S1, } \\
\text { Fig. S2 }\end{array}$ & \\
\hline \multirow[t]{2}{*}{$\begin{array}{l}\text { Karapiti (Unit } \\
\text { B) } \\
\text { (TP) }\end{array}$} & $11,287-11,632$ & $\begin{array}{l}11,460 \pm 172 \\
\text { mid } \\
11,457 \\
\text { WMA }\end{array}$ & $\begin{array}{l}\text { Bacon modelling of } \\
\text { modified Kaipo peat } \\
\text { sequence against } \\
\text { IntCal09 }\end{array}$ & $\begin{array}{l}\text { Hajdas et al. } \\
\text { (2006), Table S1 }\end{array}$ & \\
\hline & $11,397-11,605$ & $\begin{array}{l}11,501 \pm 104 \\
\text { mean }\end{array}$ & $\begin{array}{l}\text { P_Sequence modelling } \\
(\mathrm{k}=2) \text { of modified } \\
\text { Kaipo peat sequence } \\
\text { against IntCalog }\end{array}$ & $\begin{array}{l}\text { Hajdas et al. } \\
\text { (2006), Table S1, } \\
\text { Fig. S2 }\end{array}$ & \\
\hline \multirow[t]{2}{*}{$\begin{array}{l}\text { Okupata } \\
\text { (TG) }\end{array}$} & $11,574-11,959$ & $\begin{array}{l}11,767 \pm 192 \\
\text { mid } \\
11,753 \\
\text { WMA }\end{array}$ & $\begin{array}{l}\text { Bacon modelling of } \\
\text { modified Kaipo peat } \\
\text { sequence against } \\
\text { IntCal09 }\end{array}$ & $\begin{array}{l}\text { Hajdas et al. } \\
\text { (2006), Table S1 }\end{array}$ & \\
\hline & $11,711-11,923$ & $\begin{array}{l}11,817 \pm 106 \\
\text { mean }\end{array}$ & $\begin{array}{l}\text { P_Sequence modelling } \\
(\mathrm{k}=2) \text { of modified } \\
\text { Kaipo peat sequence } \\
\text { against IntCal09 }\end{array}$ & $\begin{array}{l}\text { Hajdas et al. } \\
\text { (2006), Table S1, } \\
\text { Fig. S2 }\end{array}$ & \\
\hline \multirow[t]{3}{*}{$\begin{array}{l}\text { Konini (bed b) } \\
\text { (EG) }\end{array}$} & $11,698-12,063$ & $\begin{array}{l}11,880 \pm 183 \\
\text { mid } \\
11,877 \\
\text { WMA }\end{array}$ & $\begin{array}{l}\text { Bacon modelling of } \\
\text { modified Kaipo peat } \\
\text { sequence against } \\
\text { IntCal09 }\end{array}$ & $\begin{array}{l}\text { Hajdas et al. } \\
\text { (2006), Table S1 }\end{array}$ & \multirow[t]{3}{*}{$\begin{array}{l}\text { Marks base of } \\
\text { Holocene }\end{array}$} \\
\hline & $11,834-12,035$ & $\begin{array}{l}11,935 \pm 100 \\
\text { mean }\end{array}$ & $\begin{array}{l}\text { P_Sequence modelling } \\
(\mathrm{k}=2) \text { of modified } \\
\text { Kaipo peat sequence } \\
\text { against IntCal09 }\end{array}$ & $\begin{array}{l}\text { Hajdas et al. } \\
\text { (2006), Table S1, } \\
\text { Fig. S2 }\end{array}$ & \\
\hline & $\begin{array}{l}11,404-11,956 \\
(95.4 \%)\end{array}$ & $\begin{array}{l}11,682 \pm 292 \\
\text { mean }\end{array}$ & $\begin{array}{l}\text { Calibration of } 4{ }^{14} \mathrm{C} \\
\text { ages against IntCal09 } \\
\text { via Tau_Boundary }\end{array}$ & Table 2 & \\
\hline \multirow[t]{3}{*}{$\begin{array}{l}\text { Waiohau } \\
\text { (OK) }\end{array}$} & $13,854-14,164$ & $\begin{array}{l}14,009 \pm 155 \\
\text { mid } \\
14,001 \\
\text { WMA }\end{array}$ & $\begin{array}{l}\text { Bacon modelling of } \\
\text { modified Kaipo peat } \\
\text { sequence against } \\
\text { IntCal09 }\end{array}$ & $\begin{array}{l}\text { Hajdas et al. } \\
\text { (2006), Table S1 }\end{array}$ & \\
\hline & 13,927-14,109 & $\begin{array}{l}14,018 \pm 91 \\
\text { mean }\end{array}$ & $\begin{array}{l}\text { P_Sequence modelling } \\
(\mathrm{k}=2) \text { of modified } \\
\text { Kaipo peat sequence } \\
\text { against IntCalog }\end{array}$ & $\begin{array}{l}\text { Hajdas et al. } \\
\text { (2006), Table S1, } \\
\text { Fig. S2 }\end{array}$ & \\
\hline & $\begin{array}{l}14,118-14,599 \\
(95.4 \%)\end{array}$ & $\begin{array}{l}14,324 \pm 254 \\
\text { mean }\end{array}$ & $\begin{array}{l}\text { Calibration of } 13^{14} \mathrm{C} \\
\text { ages against IntCalo9 } \\
\text { via Tau_Boundary }\end{array}$ & $\begin{array}{l}\text { Table } 3 \\
\end{array}$ & \\
\hline \multirow[t]{3}{*}{$\begin{array}{l}\text { Rotorua } \\
\text { (OK) }\end{array}$} & $15,222-16,047$ & $\begin{array}{l}15,635 \pm 412 \\
\text { mid } \\
15,601 \\
\text { WMA }\end{array}$ & $\begin{array}{l}\text { Bacon modelling of } \\
\text { modified Kaipo peat } \\
\text { sequence against } \\
\text { IntCal09 }\end{array}$ & $\begin{array}{l}\text { Hajdas et al. } \\
\text { (2006), Table S1 }\end{array}$ & \\
\hline & $15,475-16,001$ & $\begin{array}{l}15,738 \pm 263 \\
\text { mean }\end{array}$ & $\begin{array}{l}\text { P_Sequence modelling } \\
(\mathrm{k}=2) \text { of modified } \\
\text { Kaipo peat sequence } \\
\text { against IntCalog }\end{array}$ & $\begin{array}{l}\text { Hajdas et al. } \\
\text { (2006), Table S1, } \\
\text { Fig. S2 }\end{array}$ & \\
\hline & $\begin{array}{l}15,190-16,122 \\
(95.4 \%)\end{array}$ & $\begin{array}{l}15,612 \pm 506 \\
\text { mean }\end{array}$ & $\begin{array}{l}\text { Calibration of } 15^{14} \mathrm{C} \\
\text { ages against IntCalo9 } \\
\text { via Tau_Boundary }\end{array}$ & Table 3 & \\
\hline
\end{tabular}




\begin{tabular}{|c|c|c|c|c|c|}
\hline \multirow[t]{3}{*}{$\begin{array}{l}\text { Rerewhakaaitu } \\
\text { (OK) }\end{array}$} & $17,033-17,958$ & $\begin{array}{l}17,496 \pm \\
462 \text { mid } \\
17,497 \\
\text { WMA }\end{array}$ & $\begin{array}{l}\text { Bacon modelling of } \\
\text { modified Kaipo peat } \\
\text { sequence against } \\
\text { IntCal09 }\end{array}$ & $\begin{array}{l}\text { Hajdas et al. } \\
\text { (2006), Table } \\
\text { S1 }\end{array}$ & $\begin{array}{l}\text { Tephra near } \\
\text { base of bog }\end{array}$ \\
\hline & $16,960-17,458$ & $\begin{array}{l}17,209 \pm \\
249 \text { mean }\end{array}$ & $\begin{array}{l}\text { P_Sequence } \\
\text { modelling }(k=2) \text { of } \\
\text { modified Kaipo peat } \\
\text { sequence against } \\
\text { IntCal09 }\end{array}$ & $\begin{array}{l}\text { Hajdas et al. } \\
\text { (2006), Table } \\
\text { S1, Fig. S2 }\end{array}$ & \\
\hline & $\begin{array}{l}17,503-18,223 \\
(91.7 \%) \\
18,235-18,370 \\
(3.7 \%)\end{array}$ & $\begin{array}{l}17,845 \pm \\
380 \text { mean }\end{array}$ & $\begin{array}{l}\text { Calibration of } 4{ }^{14} \mathrm{C} \\
\text { ages against } \\
\text { IntCal09 via } \\
\text { Tau_Boundary }\end{array}$ & Table 3 & \\
\hline $\begin{array}{l}\text { Okareka } \\
\text { (OK) }\end{array}$ & $\begin{array}{l}21,575-22,127 \\
(95.4 \%)\end{array}$ & $\begin{array}{l}21,858 \pm \\
290 \text { mean }\end{array}$ & $\begin{array}{l}\text { Calibration of } 5{ }^{14} \mathrm{C} \\
\text { ages against } \\
\text { IntCal09 via } \\
\text { Tau_Boundary }\end{array}$ & Table 3 & \\
\hline $\begin{array}{l}\text { Te Rere } \\
\text { (OK) }\end{array}$ & $\begin{array}{l}24,432-26,191 \\
(95.4 \%)\end{array}$ & $\begin{array}{l}25,171 \pm \\
964 \text { mean }\end{array}$ & $\begin{array}{l}\text { Calibration of } 3{ }^{14} \mathrm{C} \\
\text { ages against } \\
\text { IntCal09 via } \\
\text { Tau_Boundary }\end{array}$ & Table 3 & $\begin{array}{l}\text { Samples on } \\
\text { unidentified } \\
\text { carbonised wood } \\
\text { hence in-built } \\
\text { age likely } \\
\end{array}$ \\
\hline $\begin{array}{l}\text { Kawakawa/Oruanui } \\
\text { (TP) }\end{array}$ & $\begin{array}{l}25,202-25,511 \\
(95.4 \%)\end{array}$ & $\begin{array}{l}25,358 \pm \\
162 \text { mean }\end{array}$ & $\begin{array}{l}\text { Calibration of } 22{ }^{14} \mathrm{C} \\
\text { ages against } \\
\text { IntCalo9 via } \\
\text { Tau_Boundary }\end{array}$ & Table 3 & $\begin{array}{l}\text { Vandergoes et } \\
\text { al. (in press a) }\end{array}$ \\
\hline $\begin{array}{l}\text { Poihipi } \\
\text { (TP) }\end{array}$ & $\begin{array}{l}27,860-29,155 \\
(95.4 \%)\end{array}$ & $\begin{array}{l}28,446 \pm \\
670 \text { mean }\end{array}$ & $\begin{array}{l}\text { Calibration of } 2{ }^{14} \mathrm{C} \\
\text { ages against } \\
\text { IntCal09 via } \\
\text { Tau_Boundary }\end{array}$ & Table 3 & \\
\hline $\begin{array}{l}\text { Okaia } \\
\text { (TP) }\end{array}$ & $\begin{array}{l}27,155-29,736 \\
(95.3 \%) \\
29,749-29,764 \\
(0.1 \%)\end{array}$ & $\begin{array}{l}28,621 \pm \\
1428 \text { mean }\end{array}$ & $\begin{array}{l}\text { Calibration of } 3{ }^{14} \mathrm{C} \\
\text { ages against } \\
\text { IntCal09 via } \\
\text { Tau_Boundary }\end{array}$ & Table 3 & \\
\hline
\end{tabular}

${ }^{a}$ Tephra names from Froggatt and Lowe (1990), Alloway et al. (1994, 1995), and D.J. Lowe et al. (2008); tephra unit designations from Wilson (1993). Tephra sources: OK, Okataina Volcanic Centre; TP, Taupo Volcanic Centre; TG, Tongariro Volcanic Centre; EG, Egmont volcano (also known as Mt Taranaki) (Fig. 1).

${ }^{b}$ Mid-point age of the extremes of the $95 \%$ confidence intervals (i.e., mid-points of the highest posterior density regions, HPDs) from Bacon age modelling (Blaauw and Christen, 2011), or mean age of the $95.4 \%$ confidence range from OxCal age modelling using $P$ _Sequence or Tau_Boundary functions (Bronk Ramsey, 2009a, 2009b).

'WMA, weighted mean age from Bacon modelling, a single-age representation that takes into account the general outcome of all MCMC iterations in the Bacon modelling (Blaauw and Christen, 2011).

${ }^{\mathrm{d}}$ Ages derive from (1) ${ }^{14} \mathrm{C}$ wiggle matching on logs; (2) two different Bayesian flexible age-depth

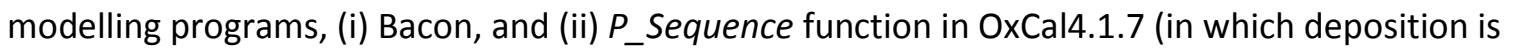
assumed to be a Poisson process), both used with the IntCal09 data set (corrected for SH offset by $44 \pm 17 \mathrm{yrs}$ ); and (3) Bayesian age-modelling program, Tau_Boundary function in OxCal4.1.7, used with the IntCal09 (corrected for SH offset by $-44 \pm 17$ yrs) or SHCal04 data sets (see text). ${ }^{\mathrm{e}}$ Konini tephra (unit b) (defined by Alloway et al., 1995) marks the base of Holocene for Australasia at the Lake Maratoto parastratoype near Hamilton in North Island, New Zealand (Walker et al., 2009). 


\begin{tabular}{|c|c|c|c|c|c|c|c|c|}
\hline Lab number ${ }^{a}$ & Location & Sample ${ }^{b}$ & $\begin{array}{l}\text { Position of } \\
\text { sample with } \\
\text { respect to } \\
\text { tephra }\end{array}$ & $\begin{array}{l}\text { Conventional } \\
\text { age }( \pm 1 \sigma) \\
{ }^{14} \mathrm{C} \text { yr BP }\end{array}$ & $\begin{array}{c}\text { Calibrated age range }^{c} \\
(95.4 \%) \\
\text { cal. yr BP }\end{array}$ & $\begin{array}{c}\text { Mean } \\
\text { calibrated } \\
\text { age }^{c}( \pm 2 \sigma) \\
\text { cal. yr BP }\end{array}$ & References & Comments \\
\hline \multicolumn{9}{|c|}{ Mapara (Unit X) ${ }^{\mathrm{d}}$} \\
\hline NZ178 & \begin{tabular}{|l} 
Access road \\
to Bore 203, \\
Wairakei
\end{tabular} & $\mathrm{CH}$ & $\begin{array}{l}\text { In base of } \\
\text { overlying tephra }\end{array}$ & $2100 \pm 100$ & \multirow{2}{*}{$\begin{array}{l}835-2098(95.4 \%) \\
n=2, \text { post-eruption } \\
\text { boundary }\end{array}$} & \multirow{2}{*}{$1689 \pm 706$} & \multirow{2}{*}{$\begin{array}{l}\text { Grant-Taylor and } \\
\text { Rafter (1963); Healy } \\
\text { (1964) }\end{array}$} & \multirow[t]{2}{*}{$\begin{array}{l}\text { See also Vucetich and Pullar } \\
\text { (1973); Wilson (1993) }\end{array}$} \\
\hline NZ1068 & $\begin{array}{l}\text { Lukes Rd, } \\
\text { Awakeri }\end{array}$ & PT & Above & $2010 \pm 60$ & & & & \\
\hline Wk1289 & $\begin{array}{l}\text { Kopouatai } \\
\text { bog }\end{array}$ & PT & Straddles & $2130 \pm 60$ & $\begin{array}{l}1941-2155(95.4 \%) \\
n=1 \text {, eruption }\end{array}$ & $\begin{array}{l}2059 \pm 118 \\
(n=7)\end{array}$ & $\begin{array}{l}\text { Newnham et al. } \\
\text { (1995a) }\end{array}$ & See Gehrels et al. (2006) \\
\hline NZ157 & $\begin{array}{l}\text { Taupo- } \\
\text { Rotorua Rd }\end{array}$ & CW & $\begin{array}{l}\text { In paleosol } \\
\text { beneath tephra }\end{array}$ & $2270 \pm 100$ & \multirow{4}{*}{$\begin{array}{l}2035-2655(95.1 \%) \\
2662-2675(0.2 \%) \\
2683-2689(0.1 \%) \\
n=4, \text { pre-eruption } \\
\text { boundary }\end{array}$} & \multirow{4}{*}{$2266 \pm 402$} & \multirow{2}{*}{$\begin{array}{l}\text { Grant-Taylor and } \\
\text { Rafter (1963); Healy } \\
\text { (1964) }\end{array}$} & \multirow{2}{*}{$\begin{array}{l}\text { See also Vucetich and Pullar } \\
\text { (1973); Wilson (1993) }\end{array}$} \\
\hline NZ1069 & $\begin{array}{l}\text { Lukes Rd, } \\
\text { Awakeri }\end{array}$ & PT & Below & $2150 \pm 50$ & & & & \\
\hline NZA14816 & Round Lake & LSps & Below & $2286 \pm 50$ & & & $\begin{array}{l}\text { Chester and Prior } \\
(2004)\end{array}$ & \\
\hline Wk1503 & $\begin{array}{l}\text { Papamoa } \\
\text { Beach bog }\end{array}$ & PT & Below & $2230 \pm 50$ & & & Wigley (1990) & \\
\hline Wk1869 & Lake Tutira & LS & Straddles & $3240 \pm 60$ & \multicolumn{2}{|c|}{$\begin{array}{l}\text { Not included in age modelling because of likely } \\
\text { hardwater effect }\end{array}$} & Eden et al. (1993) & Too old \\
\hline \multicolumn{9}{|c|}{ Whakaipo (Unit V) } \\
\hline NZ171 & $\begin{array}{l}\text { Whakamaru- } \\
\text { Tihoi Rd }\end{array}$ & BT & $\begin{array}{l}\text { In paleosol on } \\
\text { Whakaipo }\end{array}$ & $2650 \pm 150$ & \multirow{6}{*}{$\begin{array}{l}2443-2787(95.4 \%) \\
n=6, \text { post-eruption } \\
\text { boundary }\end{array}$} & \multirow{6}{*}{$2659 \pm 214$} & \multirow[t]{2}{*}{$\begin{array}{l}\text { Grant-Taylor and } \\
\text { Rafter (1963); Healy } \\
\text { (1964) }\end{array}$} & $\begin{array}{l}\text { See also Vucetich and Pullar } \\
\text { (1973); Wilson (1993) }\end{array}$ \\
\hline NZ177 & $\begin{array}{l}\text { Terraces pit, } \\
\text { Napier Rd }\end{array}$ & CW & $\begin{array}{l}\text { In paleosol on } \\
\text { Whakaipo }\end{array}$ & $2530 \pm 70$ & & & & $\begin{array}{l}\text { Age confirmed by C. Prior } \\
\text { (pers. comm., 2012) }\end{array}$ \\
\hline NZ1070 & $\begin{array}{l}\text { Lukes Rd, } \\
\text { Awakeri }\end{array}$ & PT & Above & $2670 \pm 50$ & & & $\begin{array}{l}\text { Grant-Taylor and } \\
\text { Rafter (1971) }\end{array}$ & \\
\hline Wk537 & $\begin{array}{l}\text { Lake } \\
\text { Rotomanuka }\end{array}$ & LS & Above & $2560 \pm 60$ & & & Lowe (1988) & See also Hogg et al. (1987) \\
\hline Wk1441 & $\begin{array}{l}\text { Papamoa } \\
\text { bog }\end{array}$ & PT & Above & $2670 \pm 70$ & & & $\begin{array}{l}\text { Newnham et al. } \\
\text { (1995b) }\end{array}$ & \\
\hline Wk1834 & $\begin{array}{l}\text { East Lake } \\
\text { Taupo }\end{array}$ & $\mathrm{CH}$ & $\begin{array}{l}\text { In paleosol on } \\
\text { Unit } \mathrm{V}\end{array}$ & $2780 \pm 70$ & & & Wilson (1993) & \\
\hline
\end{tabular}

\begin{tabular}{|c|c|c|c|c|c|c|c|c|}
\hline NZ182 & $\begin{array}{l}\text { Kaimanawa } \\
\text { Rd }\end{array}$ & $\mathrm{CH}$ & Within ash & $2800 \pm 100$ & \multirow{2}{*}{$\begin{array}{l}2749-2862(95.4 \%) \\
n=2, \text { eruption }\end{array}$} & \multirow{2}{*}{$\begin{array}{l}2800 \pm 60 \\
(n=12)\end{array}$} & $\begin{array}{l}\text { Grant-Taylor and } \\
\text { Rafter (1963); Healy } \\
\text { (1964) }\end{array}$ & \multirow{2}{*}{\begin{tabular}{|l|}
$\begin{array}{l}\text { See also Vucetich and Pullar } \\
\text { (1973); Wilson (1993) }\end{array}$ \\
See Gehrels et al. (2006) \\
\end{tabular}} \\
\hline Wk1017 & $\begin{array}{l}\text { Kopouatai } \\
\text { bog }\end{array}$ & PT & Straddles & $2900 \pm 110$ & & & $\begin{array}{l}\text { Newnham et al. } \\
\text { (1995a) }\end{array}$ & \\
\hline NZ1071 & $\begin{array}{l}\text { Lukes Rd, } \\
\text { Awakeri }\end{array}$ & PT & Below & $2730 \pm 60$ & \multirow{4}{*}{$\begin{array}{l}2788-3358(95.4 \%) \\
n=4, \text { pre-eruption } \\
\text { boundary }\end{array}$} & \multirow{4}{*}{$2995 \pm 374$} & $\begin{array}{l}\text { Grant-Taylor and } \\
\text { Rafter (1971) }\end{array}$ & \\
\hline Wk506 & Lake Kainui & LS & Below & $3010 \pm 70$ & & & Lowe (1988) & \multirow{2}{*}{ See also Hogg et al. (1987) } \\
\hline Wk538 & $\begin{array}{l}\text { Lake } \\
\text { Rotomanuka }\end{array}$ & LS & Below & $2860 \pm 60$ & & & & \\
\hline Wk1442 & $\begin{array}{l}\text { Papamoa } \\
\text { bog }\end{array}$ & PT & Below & $2710 \pm 80$ & & & $\begin{array}{l}\text { Newnham et al. } \\
\text { (1995b) }\end{array}$ & \\
\hline NZ184 & $\begin{array}{l}\text { Pohokura } \\
\text { Rd, Tutira }\end{array}$ & $\mathrm{CH}$ & $\begin{array}{l}\text { Within } \\
\text { pumiceous ash }\end{array}$ & $2400 \pm 80$ & \multirow{2}{*}{\multicolumn{2}{|c|}{ Rejected as outliers (this study) }} & $\begin{array}{l}\text { Grant-Taylor and } \\
\text { Rafter (1963); Healy } \\
(1964)\end{array}$ & \\
\hline NZ2740 & $\begin{array}{l}\text { Kaingaroa } \\
\text { Forest }\end{array}$ & $\mathrm{CH}$ & $\begin{array}{l}\text { In paleosol } \\
\text { beneath tephra }\end{array}$ & $2520 \pm 65$ & & & $\begin{array}{l}\text { Collected by W.A. } \\
\text { Pullar (not I.A. Nairn); } \\
\text { Froggatt and Lowe } \\
\text { (1990) }\end{array}$ & $\begin{array}{l}\text { Age confirmed by C. Prior } \\
\text { (pers. comm., 2012) }\end{array}$ \\
\hline Wk507 & Lake Kainui & LS & Above & $2010 \pm 80$ & \multicolumn{2}{|c|}{$\begin{array}{l}\text { Not included in age modelling because } \\
\text { tephrostratigraphy indicates age is an outlier }\end{array}$} & Lowe (1988) & Too young \\
\hline AA-54137 & $\begin{array}{l}\text { Kopouatai } \\
\text { bog }\end{array}$ & PT & Below & $2962 \pm 38$ & \multicolumn{2}{|c|}{$\begin{array}{l}\text { Not included in age modelling because sample position } \\
\text { too far from tephra (not contiguous) }\end{array}$} & Gehrels et al. (2006) & $15 \mathrm{~cm}$ below tephra \\
\hline \multicolumn{9}{|c|}{ Stent (Unit Q) } \\
\hline Wk1443 & \multirow[t]{3}{*}{$\begin{array}{l}\text { Papamoa } \\
\text { bog }\end{array}$} & PT & Above & $4060 \pm 80$ & $\begin{array}{l}3075-4389(94.1 \%) \\
3053-3069(0.4 \%) \\
3027-3048(0.5 \% \\
3009-3020(0.3 \%) \\
2994-3001(0.2 \%) \\
n=1, \text { post-eruption } \\
\text { boundary }\end{array}$ & $3902 \pm 802$ & $\begin{array}{l}\text { Newnham et al. } \\
\text { (1995b) }\end{array}$ & \multirow[t]{3}{*}{ See also Wilson (1993) } \\
\hline Wk1565 & & PT & Straddles & $4030 \pm 70$ & \multirow{2}{*}{$\begin{array}{l}4224-4418(93.9 \%) \\
4185-4200(1.5 \%) \\
n=2, \text { eruption }\end{array}$} & \multirow{2}{*}{$\begin{array}{l}4322 \pm 112 \\
(n=7)\end{array}$} & Alloway et al. (1994) & \\
\hline Wk2151 & & PT & Straddles & $3820 \pm 70$ & & & $\begin{array}{l}\text { Newnham et al. } \\
\text { (1995b) }\end{array}$ & \\
\hline
\end{tabular}




\begin{tabular}{|c|c|c|c|c|c|c|c|c|}
\hline Wk1032 & $\begin{array}{l}\text { Sutton Rd } \\
\text { beach near } \\
\text { Waitara }\end{array}$ & PT & Below & $3870 \pm 110$ & \multirow{4}{*}{$\begin{array}{l}4258-4822(95.4 \%) \\
n=4, \text { pre-eruption } \\
\text { boundary }\end{array}$} & \multirow[t]{4}{*}{$4489 \pm 362$} & Alloway et al. (1994) & \\
\hline Wk1259 & $\begin{array}{l}\text { Mangamingi } \\
\text { near Eltham }\end{array}$ & PT & Below & $3940 \pm 70$ & & & & \\
\hline Wk1444 & \multirow{2}{*}{$\begin{array}{l}\text { Papamoa } \\
\text { bog }\end{array}$} & PT & Below & $3910 \pm 110$ & & & $\begin{array}{l}\text { Newnham et al. } \\
\text { (1995b) }\end{array}$ & \\
\hline Wk1564 & & WD & Below & $4140 \pm 80$ & & & Alloway et al. (1994) & \\
\hline AA54139 & $\begin{array}{l}\text { Kopouatai } \\
\text { bog }\end{array}$ & PT & Above & $4116 \pm 41$ & \multicolumn{2}{|c|}{$\begin{array}{l}\text { Not included in age modelling because sample position } \\
\text { too far from tephra (not contiguous) }\end{array}$} & Gehrels et al. (2006) & $38 \mathrm{~cm}$ above tephra \\
\hline NZ6702 & $\begin{array}{l}\text { Kaimata } \\
\text { near } \\
\text { Inglewood }\end{array}$ & PT & Below & $3580 \pm 80$ & \multicolumn{2}{|c|}{$\begin{array}{l}\text { Not included in age modelling because sample } \\
\text { reported as possibly contaminated by Alloway et al. } \\
\text { (1994), and tephrostratigraphy indicates age is an } \\
\text { outlier }\end{array}$} & Alloway et al. (1994) & Too young \\
\hline
\end{tabular}

\begin{tabular}{|c|c|c|c|c|c|c|c|c|}
\hline Wk241 & \multirow{2}{*}{$\begin{array}{l}\text { Kopouatai } \\
\text { bog }\end{array}$} & PT & Above & $6070 \pm 80$ & \multirow{4}{*}{$\begin{array}{l}5917-7018(95.1) \\
5858-5892(0.3 \%) \\
n=4, \text { post-eruption } \\
\text { boundary }\end{array}$} & \multirow{4}{*}{$6609+-656$} & \multirow{2}{*}{$\begin{array}{l}\text { Hogg and McCraw } \\
\text { (1983) }\end{array}$} & \multirow{3}{*}{ See also Hogg et al. (1987) } \\
\hline Wk244 & & PT & Above & $6060 \pm 80$ & & & & \\
\hline Wk505 & Lake Kainui & LS & Above & $5800 \pm 90$ & & & Lowe (1988) & \\
\hline Wk1317 & $\begin{array}{l}\text { Kopouatai } \\
\text { bog }\end{array}$ & PT & Above & $6130 \pm 100$ & & & $\begin{array}{l}\text { Newnham et al. } \\
\text { (1995a) }\end{array}$ & \\
\hline Wk77 & $\begin{array}{l}\text { Mayor Island } \\
\text { (Tuhua) }\end{array}$ & $\mathrm{CW}$ & $\begin{array}{l}\text { In paleosol } \\
\text { under Tuhua fall }\end{array}$ & $6340 \pm 190$ & $\begin{array}{l}6868-7206(95.4 \%) \\
n=1, \text { eruption }\end{array}$ & $\begin{array}{l}7027 \pm 170 \\
(n=10)\end{array}$ & Buck et al. (1981) & \\
\hline Wk106 & $\begin{array}{l}\text { Kopouatai } \\
\text { bog }\end{array}$ & PT & Below & $6280 \pm 70$ & & & $\begin{array}{l}\text { Hogg and McCraw } \\
\text { (1983) }\end{array}$ & \\
\hline Wk214 & $\begin{array}{l}\text { Lake } \\
\text { Maratoto }\end{array}$ & LS & Below & $6210 \pm 70$ & & $7413+528$ & Lowe (1988) & See also Hogg et al. (1987) \\
\hline Wk242 & & PT & Below & $6440 \pm 80$ & $n=5$, pre-eruption & 海 & $\begin{array}{l}\text { Hogg and McCraw } \\
\text { (1983) }\end{array}$ & \\
\hline Wk243 & Kopouatai & PT & Below & $6710 \pm 80$ & boundary & & & $\begin{array}{l}\text { Thick sample. See also Hogg et } \\
\text { al. (1987) }\end{array}$ \\
\hline Wk1318 & & PT & Below & $6440 \pm 120$ & & & $\begin{array}{l}\text { Newnham et al. } \\
\text { (1995a) }\end{array}$ & \\
\hline NZ333 & & PT & Below & $5370 \pm 54$ & & & $\begin{array}{l}\text { Grant-Taylor and } \\
\text { Rafter (1963) }\end{array}$ & $\begin{array}{l}\text { Tephra identification } \\
\text { uncertain }\end{array}$ \\
\hline Wk525 & $\begin{array}{l}\text { Lake } \\
\text { Maratoto }\end{array}$ & LS & Below & $5800 \pm 70$ & Rejected as outliers (this & & Lowe (1988) & $\begin{array}{l}\text { Thick sample. See Hogg et al. } \\
\text { (1987) }\end{array}$ \\
\hline Wk1019 & Kopouatai & PT & Above & $5280 \pm 130$ & $\begin{array}{l}\text { Not included in age modellir } \\
\text { too far from tephra (not con } \\
\text { tephrostratigraphy indicate }\end{array}$ & $\begin{array}{l}\text { cause sample position } \\
\text { us) and } \\
\text { iple is outlier }\end{array}$ & $\begin{array}{l}\text { Froggatt and Lowe } \\
\text { (1990) }\end{array}$ & \\
\hline SUERC1517 & & PT & $\begin{array}{l}36 \mathrm{~cm} \text { above } \\
\text { tephra }\end{array}$ & $6017 \pm 34$ & & & Gehrels et al. (2006) & \\
\hline OZH877 & Lake Pupuke & LS & $\begin{array}{l}13 \mathrm{~cm} \text { below } \\
\text { tephra }\end{array}$ & $6540 \pm 80$ & $\begin{array}{l}\text { Not included in age modellir } \\
\text { too far from tephra (not con }\end{array}$ & $\begin{array}{l}\text { :ause sample position } \\
\text { us) }\end{array}$ & $\begin{array}{l}\text { Augustinus et al. } \\
\text { (2008) }\end{array}$ & \\
\hline OZD508 & $\begin{array}{l}\text { Pukaki } \\
\text { crater }\end{array}$ & CS & $\begin{array}{l}20 \mathrm{~cm} \text { below } \\
\text { tephra }\end{array}$ & $6900 \pm 70$ & & & Sandiford et al. (2001) & $\begin{array}{l}\text { Not corrected for marine } \\
\text { reservoir; in marine clays }\end{array}$ \\
\hline
\end{tabular}

\begin{tabular}{|c|c|c|c|c|c|c|c|c|}
\hline \multicolumn{9}{|c|}{ Opepe (Unit E) } \\
\hline Wk229 & $\begin{array}{l}\text { Lake } \\
\text { Maratoto }\end{array}$ & LS & Above & $7650 \pm 160$ & \multirow{5}{*}{$\begin{array}{l}7527-9705(95.1 \%) \\
7474-7519(0.3 \%) \\
n=5, \text { post-eruption } \\
\text { boundary }\end{array}$} & \multirow{5}{*}{$8852 \pm 1306$} & $\begin{array}{l}\text { Hogg et al. (1987); } \\
\text { Lowe (1988) }\end{array}$ & $\begin{array}{l}\text { Compressed sediment also } \\
\text { abuts overlying Mamaku } \\
\text { tephra }\end{array}$ \\
\hline Wk492 & Kaipo bog & PT & Above & $8710 \pm 80$ & & & $\begin{array}{l}\text { Lowe and Hogg } \\
\text { (1986); Lowe et al. } \\
\text { (1999) }\end{array}$ & \\
\hline Wk521 & $\begin{array}{l}\text { Lake } \\
\text { Maratoto }\end{array}$ & PT & Above & $8670 \pm 110$ & & & Lowe (1988) & See also Hogg et al. (1987) \\
\hline Wk1000 & $\begin{array}{l}\text { Three Kings } \\
\text { bog }\end{array}$ & PT & Above & $7910 \pm 70$ & & & $\begin{array}{l}\text { Froggatt and Rogers } \\
(1990)\end{array}$ & \\
\hline Wk1292 & $\begin{array}{l}\text { Kopouatai } \\
\text { bog }\end{array}$ & PT & Above & $9050 \pm 120$ & & & $\begin{array}{l}\text { Newnham et al. } \\
\text { (1995a) }\end{array}$ & \\
\hline Wk713 & $\begin{array}{l}\text { Lake } \\
\text { Rotongata }\end{array}$ & LS & Straddles & $8990 \pm 220$ & \multirow{2}{*}{$\begin{array}{l}9682-10,140(95.4 \%) \\
n=2, \text { eruption }\end{array}$} & \multirow{2}{*}{$\begin{array}{l}9906 \pm 246 \\
(n=11)\end{array}$} & Lowe (1988) & \\
\hline Wk1320 & $\begin{array}{l}\text { Kopouatai } \\
\text { bog }\end{array}$ & PT & Straddles & $8390 \pm 280$ & & & $\begin{array}{l}\text { Newnham et al. } \\
\text { (1995a) }\end{array}$ & \\
\hline Wk230 & \multirow[t]{2}{*}{$\begin{array}{l}\text { Lake } \\
\text { Maratoto }\end{array}$} & LS & Below & $9370 \pm 210$ & \multirow{4}{*}{$\begin{array}{l}9810-11,001(95.3 \%) \\
11,009-11,019(0.1 \%) \\
n=4, \text { pre-eruption } \\
\text { boundary }\end{array}$} & \multirow{4}{*}{$10,274 \pm 684$} & \multirow{3}{*}{ Lowe (1988) } & \multirow{3}{*}{ See also Hogg et al. (1987) } \\
\hline Wk520 & & LS & Below & $8930 \pm 100$ & & & & \\
\hline Wk707 & $\begin{array}{l}\text { Lake } \\
\text { Okoroire }\end{array}$ & LS & Below & $8700 \pm 130$ & & & & \\
\hline Wk1291 & $\begin{array}{l}\text { Kopouatai } \\
\text { bog }\end{array}$ & PT & Below & $9060 \pm 110$ & & & $\begin{array}{l}\text { Newnham et al. } \\
\text { (1995a) }\end{array}$ & \\
\hline Wk1335 & $\begin{array}{l}\text { Near } \\
\text { Tauhara } \\
\text { Quarry }\end{array}$ & $\mathrm{CH}$ & In ignimbrite & $9600 \pm 70$ & \multicolumn{2}{|c|}{ Rejected as outlier (this study) } & $\begin{array}{l}\text { P.C. Froggatt in } \\
\text { Froggatt and Lowe } \\
(1990)\end{array}$ & \\
\hline NZ185 & & $\mathrm{CHf}$ & $\begin{array}{l}\text { In paleosol } \\
\text { below tephra }\end{array}$ & $8850 \pm 1000$ & \multicolumn{2}{|c|}{$\begin{array}{l}\text { Not included in age modelling because of excessive } \\
\text { error }\end{array}$} & $\begin{array}{l}\text { Grant-Taylor and } \\
\text { Rafter (1963) }\end{array}$ & $\begin{array}{l}\text { See also Vucetich and Pullar } \\
\text { (1973) }\end{array}$ \\
\hline
\end{tabular}




\begin{tabular}{|c|c|c|c|c|c|c|c|c|}
\hline \multicolumn{9}{|c|}{ Konini (bed b) } \\
\hline Wk519 & $\begin{array}{l}\text { Lake } \\
\text { Maratoto }\end{array}$ & PT & $\begin{array}{l}\text { Straddling } \\
\text { tephra }\end{array}$ & $10,100 \pm 100$ & $\begin{array}{l}9183-11,791(94.9 \%) \\
9147-9161(0.2 \%) \\
9120-9131(0.2 \%) \\
9060-9067(0.1 \%) \\
n=1,{ }^{\prime} p o s t^{\prime}-\text { eruption } \\
\text { boundary }\end{array}$ & $\begin{array}{l}10,780 \pm \\
1524\end{array}$ & Lowe (1988) & $\begin{array}{l}\text { Designated 'above' tephra in } \\
\text { age modelling }\end{array}$ \\
\hline NZ3153 & $\begin{array}{l}\text { Eltham } \\
\text { swamp }\end{array}$ & PT & $\begin{array}{l}\text { Enveloping } \\
\text { tephra }\end{array}$ & $10,150 \pm 100$ & $\begin{array}{l}11,404-11,956(95.4 \%) \\
n=1, \text { eruption }\end{array}$ & $\begin{array}{l}11,682 \pm 292 \\
(n=4)\end{array}$ & $\begin{array}{l}\text { McGlone and Neall } \\
\text { (1994); Alloway et al. } \\
\text { (1995) }\end{array}$ & \\
\hline $\begin{array}{l}\text { Wk5404/ } \\
\text { NZA7751 }\end{array}$ & Kaipo bog & PT & Below & $10,146 \pm 76$ & $\begin{array}{l}11,513-14,778(95.3 \%) \\
14,783-14,814(0.1 \%) \\
n=2, \text { pre-eruption } \\
\text { boundary }\end{array}$ & $\begin{array}{l}12,585 \pm \\
1854\end{array}$ & Lowe et al. (1999) & $\begin{array}{l}\text { NZ lab number misreported as } \\
\text { NZ7761 in Lowe et al. (1999) }\end{array}$ \\
\hline
\end{tabular}

${ }^{a}$ Radiocarbon laboratories: NZ, NZA = Rafter (formerly New Zealand), Lower Hutt, New Zealand; Wk = Waikato, Hamilton, New Zealand; AA, SUERC = NERC Radiocarbon Laboratory, East Kilbride, Scotland, UK (AMS); OZH, OZD = ANSTO, Canberra, Australia.

${ }^{\mathrm{b}} \mathrm{CH}$, charcoal; PT, peat; CW, charred/carbonised wood; LSps, pollen and spores extracted from organic lake sediment; LS, organic lake sediment;

BT, small branches and twigs; WD, wood; CS, cockle shell; CHf, charcoal 'flecks'.

'Calibrations were made using SHCal04 (McCormac et al., 2004) for all tephras except Konini tephra, for which IntCal09 was used (Reimer et al., 2009) after firstly subtracting $44 \pm 17$ years from conventional ${ }^{14} \mathrm{C}$ ages for the Southern Hemisphere offset (Hogg et al., 2011). Ages shown in bold are the new eruption ages (based on $n$ ages in total) that we have determined for the tephras using modelling via the Tau_Boundary function in OxCal4.1.7 (Bronk Ramsey, 2009a, 2009b), which incorporates stratigraphic information (summarised as the pre-eruption and post-eruption boundary ages for samples below and above tephras, respectively) as well as the ${ }^{14} \mathrm{C}$ age data.

Tephra names from Froggatt and Lowe (1990) and Alloway et al. (1994, 1995); tephra unit designations from Wilson (1993). 
Table 3 Radiocarbon ages and the OxCal Tau_Boundary modelling procedures used in deriving calibrated ages for eight pre-Holocene marker tephras: Waiohau, Rotorua, Rerewhakaaitu, Okareka, Te Rere, Kawakawa/Oruanui, Poihipi, and Okaia. Eruption ages in bold. (See Table 1 for a summary of all tephra ages derived in this paper.)

\begin{tabular}{|c|c|c|c|c|c|c|c|c|}
\hline $\begin{array}{c}\text { Lab } \\
\text { number }\end{array}$ & Location & Sample $^{b}$ & $\begin{array}{l}\text { Position of } \\
\text { sample with } \\
\text { respect to } \\
\text { tephra }\end{array}$ & $\begin{array}{l}\text { Conventional } \\
\text { age }( \pm 1 \sigma) \\
{ }^{14} \mathrm{C} \mathrm{yr} \mathrm{BP}\end{array}$ & $\begin{array}{c}\text { Calibrated age range }^{c} \\
(95.4 \%) \\
\text { cal. yr BP }\end{array}$ & $\begin{array}{l}\text { Mean calibrated } \\
\text { age }^{c}( \pm 2 \sigma) \\
\text { cal. yr BP }^{-}\end{array}$ & References $^{d}$ & Comments \\
\hline
\end{tabular}

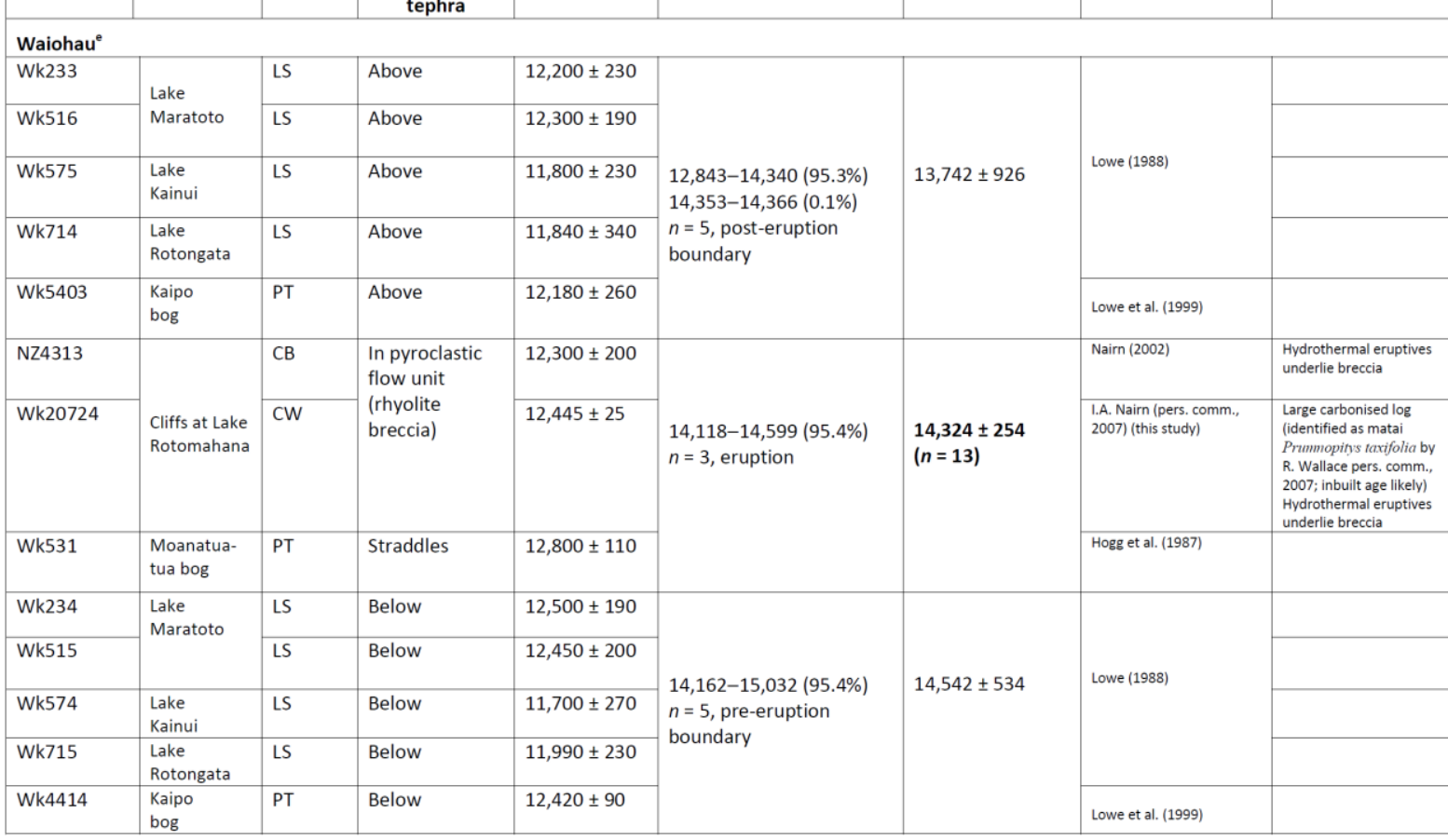

\begin{tabular}{|c|c|c|c|c|c|c|c|c|}
\hline NZ568 & Mt Tarawera & $\mathrm{CH}$ & Near base & $11,312 \pm 88$ & \multirow{4}{*}{\multicolumn{2}{|c|}{ Rejected as outliers (this study) }} & Cole (1970) & \multirow{3}{*}{$\begin{array}{l}\text { Conventional ages re- } \\
\text { calculated by R. Sparks } \\
\text { (pers. comm., 1998) }\end{array}$} \\
\hline NZ878 & \multirow{2}{*}{$\begin{array}{l}\text { Near } \\
\text { Lake Rotoiti }\end{array}$} & WD & Below & $11,100 \pm 219$ & & & $\begin{array}{l}\text { Grant-Taylor and Rafter } \\
\text { (1971) }\end{array}$ & \\
\hline NZ1135 & & $\mathrm{CH}$ & Below & $11,795 \pm 134$ & & & Pullar and Heine (1971) & \\
\hline Wk709 & \multirow{2}{*}{$\begin{array}{l}\text { Lake } \\
\text { Okoroire }\end{array}$} & LS & Below & $11,570 \pm 130$ & & & Lowe (1988) & \\
\hline Wk708 & & LS & Above & $10,220 \pm 160$ & \multicolumn{2}{|c|}{$\begin{array}{l}\text { Not included in age modelling because tephrostratigraphy } \\
\text { indicates age is an outlier }\end{array}$} & Lowe (1988) & Too young \\
\hline NZA6655 & $\mathrm{H} 214$ & $\operatorname{PF}(G i)$ & \multirow{2}{*}{$\begin{array}{l}\text { Above } \\
\text { (within } 10 \\
\mathrm{~mm} \text { ) }\end{array}$} & $12,820 \pm 110^{f}$ & \multirow{5}{*}{\multicolumn{2}{|c|}{$\begin{array}{l}\text { Not included in age modelling because of uncertain marine } \\
\text { reservoir correction }\end{array}$}} & \multirow{5}{*}{$\begin{array}{l}\text { Sikes et al. (2000), Samson } \\
\text { et al. (2005) }\end{array}$} & \multirow{5}{*}{$\begin{array}{l}\text { Marine samples. D.J. } \\
\text { Lowe et al. (2008) } \\
\text { reported ages with } \\
\text { corrections of } 776 \text { years } \\
\text { based on Carter et al. } \\
\text { (2008). This correction is } \\
\text { now excessive (see text) }\end{array}$} \\
\hline CAMS39603 & $\mathrm{H} 211$ & $\operatorname{PF}(G i)$ & & $12,130 \pm 50^{\dagger}$ & & & & \\
\hline NZA6662 & $\mathrm{H} 214$ & $\operatorname{PF}(G i)$ & \multirow{3}{*}{$\begin{array}{l}\text { Below } \\
\text { (within } 10 \\
\mathrm{~mm} \text { ) }\end{array}$} & $12,910 \pm 140^{f}$ & & & & \\
\hline NZA6668 & $\mathrm{H} 211$ & $\operatorname{PF}(G i)$ & & $12,750 \pm 160^{f}$ & & & & \\
\hline CAMS40463 & $\mathrm{H} 209$ & $\mathrm{PF}(G i)$ & & $12,640 \pm 50^{f}$ & & & & \\
\hline \multicolumn{9}{|l|}{ Rotorua } \\
\hline NZ1187 & Tongariro & $\mathrm{CH}$ & Above & $12,350 \pm 220$ & \multirow{7}{*}{$\begin{array}{l}14,013-15,567(95.4 \%) \\
n=7 \text {, post-eruption } \\
\text { boundary }\end{array}$} & \multirow{7}{*}{$14,898 \pm 878$} & Topping and Kohn (1973) & $\begin{array}{l}\text { Tephra identification } \\
\text { uncertain }\end{array}$ \\
\hline NZ3090 & \multirow[t]{2}{*}{$\begin{array}{l}\text { Kaingaroa } \\
\text { Forest }\end{array}$} & $\mathrm{CH}$ & $\begin{array}{l}\text { In paleosol on } \\
\text { tephra }\end{array}$ & $13,900 \pm 300$ & & & $\begin{array}{l}\text { Rafter Lab files (C. Prior } \\
\text { pers. comm., 2012) }\end{array}$ & May have in-built age \\
\hline NZ4185 & & $\mathrm{CHr}$ & $\begin{array}{l}\text { In paleosol on } \\
\text { tephra }\end{array}$ & $12,810 \pm 580$ & & & $\begin{array}{l}\text { K. Goh in Froggatt and } \\
\text { Lowe (1990) }\end{array}$ & $\begin{array}{l}\text { Humic acid extract dated } \\
\text { at } 6710 \pm 260^{14} \mathrm{C} \text { C Br BP } \\
\text { (NZ4183) }\end{array}$ \\
\hline Wk235 & \multirow[t]{2}{*}{$\begin{array}{l}\text { Lake } \\
\text { Maratoto }\end{array}$} & LS & Above & $12,900 \pm 310$ & & & Lowe (1988) & \\
\hline Wk512 & & LS & Above & $12,800 \pm 150$ & & & & \\
\hline Wk530 & $\begin{array}{l}\text { Moanatua- } \\
\text { tua bog }\end{array}$ & PT & Above & $12,950 \pm 110$ & & & Hogg et al. (1987) & \\
\hline Wk573 & Lake Kainui & LS & Above & $12,350 \pm 210$ & & & Lowe (1988) & Disturbed sediment? \\
\hline
\end{tabular}




\begin{tabular}{|c|c|c|c|c|c|c|c|c|}
\hline NZ1615 & $\begin{array}{l}\text { Trig } 7696 \\
\text { east of Lake } \\
\text { Rotokakahi }\end{array}$ & CT & Within & $13,450 \pm 250$ & \multirow{2}{*}{$\begin{array}{l}15,190-16,122(95.4 \%) \\
n=2, \text { eruption }\end{array}$} & \multirow{2}{*}{$\begin{array}{l}15,612 \pm 506 \\
(n=15)\end{array}$} & Nairn $(1980,2002)$ & \\
\hline Wk9851 & $\begin{array}{l}\text { Rerewhaka- } \\
\text { aitu Forest }\end{array}$ & $\mathrm{CH}$ & $\begin{array}{l}\text { Within } \\
\text { pyroclastic } \\
\text { flow unit }\end{array}$ & $12,941 \pm 75$ & & & $\begin{array}{l}\text { Kilgour (2002); Kilgour and } \\
\text { Smith (2008) }\end{array}$ & $\begin{array}{l}\text { Charcoal from large } \\
\text { charred log, phase } 2 \text { of } \\
\text { eruption (G.N. Kilgour } \\
\text { pers. comm., 2012) }\end{array}$ \\
\hline NZ1186 & Tongariro & $\mathrm{CH}$ & Below & $13,150 \pm 300$ & \multirow{6}{*}{$\begin{array}{l}15,532-17,088(95.1 \%) \\
17,093-17,124(0.3 \%) \\
n=6, \text { pre-eruption } \\
\text { boundary }\end{array}$} & \multirow{6}{*}{$16,234 \pm 904$} & Topping and Kohn (1973) & Identification uncertain \\
\hline Wk236 & \multirow[t]{2}{*}{$\begin{array}{l}\text { Lake } \\
\text { Maratoto }\end{array}$} & LS & Below & $12,600 \pm 230$ & & & \multirow{2}{*}{ Lowe (1988) } & \\
\hline Wk511 & & LS & Below & $13,450 \pm 120$ & & & & \\
\hline Wk529 & $\begin{array}{l}\text { Moanatua- } \\
\text { tua bog }\end{array}$ & PT & Below & $13,300 \pm 110$ & & & Hogg et al. (1987) & \\
\hline Wk572 & Lake Kainui & LS & Below & $12,650 \pm 230$ & & & Lowe (1988) & Disturbed sediment? \\
\hline Wk5163 & Kaipo bog & PT & Below & $13,420 \pm 80$ & & & $\begin{array}{l}\text { Lowe et al. (1999); Shane } \\
\text { et al. (2003) }\end{array}$ & $\begin{array}{l}\text { Peat 40-80 } \mathrm{mm} \text { below } \\
\text { tephra }\end{array}$ \\
\hline NZA9123 & $\begin{array}{l}\text { Pukaki } \\
\text { crater }\end{array}$ & LS & Below & $14,052 \pm 71$ & $\begin{array}{l}\text { Not included in age modelling bec: } \\
\text { for hardwater effect }\end{array}$ & e of uncertain correction & Sandiford et al. (2001) & $\begin{array}{l}\text { Hardwater effect likely } \\
\text { (too old) }\end{array}$ \\
\hline \multicolumn{9}{|c|}{ Rerewhakaaitu } \\
\hline Wk237 & $\begin{array}{l}\text { Lake } \\
\text { Maratoto }\end{array}$ & LS & Above & $14,700 \pm 220$ & \multirow{2}{*}{$\begin{array}{l}15,597-18,074(95.0 \%) \\
15,548-15,591(0.2 \%) \\
15,469-15,502(0.2 \%) \\
n=2, \text { post-eruption } \\
\text { boundary }\end{array}$} & \multirow[t]{2}{*}{$17,263 \pm 1364$} & Lowe (1988) & \\
\hline Wk5165 & Kaipo bog & PT & Above & $14,700 \pm 160$ & & & Lowe et al. (1999) & \\
\hline & & & & & $\begin{array}{l}17,503-18,223(91.7 \%) \\
18,235-18,370(3.7 \%) \\
\text { Eruption }\end{array}$ & $\begin{array}{l}17,845 \pm 380 \\
(n=4)\end{array}$ & & \\
\hline NZ716 & Kawerau & $\mathrm{CH}$ & Below & $14,700 \pm 200$ & \multirow{2}{*}{$\begin{array}{l}17,598-20,013(95.0 \%) \\
20,027-20,073(0.3 \%) \\
20,134-20.154(0.1 \%) \\
n=2, \text { pre-eruption } \\
\text { boundary }\end{array}$} & \multirow[t]{2}{*}{$18,421 \pm 1364$} & Vucetich and Pullar (1969) & \\
\hline Wk238 & $\begin{array}{l}\text { Lake } \\
\text { Maratoto }\end{array}$ & LS & Below & $14,700 \pm 180$ & & & Lowe (1988) & \\
\hline NZA9124 & Pukaki crater & LS & Above & $15,459 \pm 86$ & \multicolumn{2}{|c|}{$\begin{array}{l}\text { Not included in age modelling because of uncertain correction } \\
\text { for hardwater effect }\end{array}$} & Sandiford et al. (2001) & $\begin{array}{l}\text { Hardwater effect likely } \\
\text { (too old) }\end{array}$ \\
\hline
\end{tabular}

\begin{tabular}{|c|c|c|c|c|c|c|c|c|}
\hline \multicolumn{9}{|l|}{ Okareka } \\
\hline NZA16791 & $\begin{array}{l}\text { Onepoto } \\
\text { basin }\end{array}$ & LS & Above $(5 \mathrm{~mm})$ & $18,300 \pm 100$ & \multirow{2}{*}{$\begin{array}{l}19,546-22,074(95.4 \%) \\
n=2, \text { post-eruption } \\
\text { boundary }\end{array}$} & \multirow[t]{2}{*}{$21,290 \pm 1456$} & \multirow[t]{2}{*}{ Molloy et al. (2009) } & \\
\hline OZK262 & Lake Pupuke & LF & Above $(10 \mathrm{~mm})$ & $18,310 \pm 130$ & & & & \\
\hline & & & & & $\begin{array}{l}21,575-22,127(95.4 \%) \\
\text { Eruption }\end{array}$ & $\begin{array}{l}21,858 \pm 290 \\
(n=5)\end{array}$ & & \\
\hline Wk5753 & Mt Richmond & OS & Below $(10 \mathrm{~mm})$ & $18,420 \pm 140$ & \multirow{3}{*}{$\begin{array}{l}21,624-23,108(95.4 \%) \\
n=3, \text { pre-eruption } \\
\text { boundary }\end{array}$} & \multirow{3}{*}{$22,204 \pm 930$} & Sandiford et al. (2002) & \\
\hline OZH872 & $\begin{array}{l}\text { Onepoto } \\
\text { basin }\end{array}$ & LS & Below (5 mm) & $18,290 \pm 120$ & & & \multirow[t]{2}{*}{\begin{tabular}{|l|} 
Molloy et al. (2009) \\
\end{tabular}} & \\
\hline OZK263 & Lake Pupuke & LF & Below $(10 \mathrm{~mm})$ & $18,540 \pm 160$ & & & & \\
\hline NZA9125 & Pukaki crater & LS & Below & $19,100 \pm 100$ & \multicolumn{2}{|c|}{$\begin{array}{l}\text { Not included in age modelling because of uncertain correction } \\
\text { for hardwater effect }\end{array}$} & Sandiford et al. (2001) & Hardwater effect likely \\
\hline $\begin{array}{l}872-873 \mathrm{~cm} \\
\text { depth }\end{array}$ & MD97-2121 & PF & Below & $19,920 \pm 100^{f}$ & \multicolumn{2}{|c|}{$\begin{array}{l}\text { Not included in age modelling because of uncertain marine } \\
\text { reservoir correction }\end{array}$} & \begin{tabular}{|l} 
Carter et al. (2008) \\
\end{tabular} & Marine sample \\
\hline \multicolumn{9}{|l|}{ Te Rere } \\
\hline NZ523 & Rotoiti & $\mathrm{CH} / \mathrm{CW}$ & Upper ash & $20,700 \pm 450$ & \multirow{2}{*}{$\begin{array}{l}18,461-25,455(95.1 \%) \\
18,289-18,454(0.3 \%) \\
n=2, \text { post-eruption } \\
\text { boundary }\end{array}$} & \multirow[t]{2}{*}{$23,299 \pm 4034$} & Nairn $(1992,2002)$ & $\begin{array}{l}\text { Unidentified carbonised } \\
\text { wood hence in-built age } \\
\text { possible }\end{array}$ \\
\hline $\begin{array}{l}907 \mathrm{~cm} \\
\text { depth }\end{array}$ & MD97-2121 & PF & Above & $20,707 \pm 100^{f}$ & & & $\begin{array}{l}\text { B. Manhigetti \& L. Carter } \\
\text { in Lowe et al. (2008) }\end{array}$ & Marine sample \\
\hline \multirow{2}{*}{ NZ5171 } & & & & & $\begin{array}{l}24,432-26,191(95.4 \%) \\
\text { Eruption }\end{array}$ & $\begin{array}{l}25,171 \pm 964 \\
(n=3)\end{array}$ & & \\
\hline & $\begin{array}{l}\text { Near Lake } \\
\text { Rotoehu }\end{array}$ & $\mathrm{CH} / \mathrm{CW}$ & In surge beds & $21,500 \pm 450$ & $\begin{array}{l}24,899-33,595(94.4 \%) \\
33,601-33,631(0.1 \%) \\
33,637-33,762(0.6 \%) \\
33,770-33,793(0.1 \%) \\
33,881-33,913(0.2 \%) \\
n=1, \text { 'pre'-eruption } \\
\text { boundary }\end{array}$ & $28,434 \pm 5298$ & Nairn $(1992,2002)$ & $\begin{array}{l}\text { Designated 'below' } \\
\text { tephra in age modelling }\end{array}$ \\
\hline
\end{tabular}




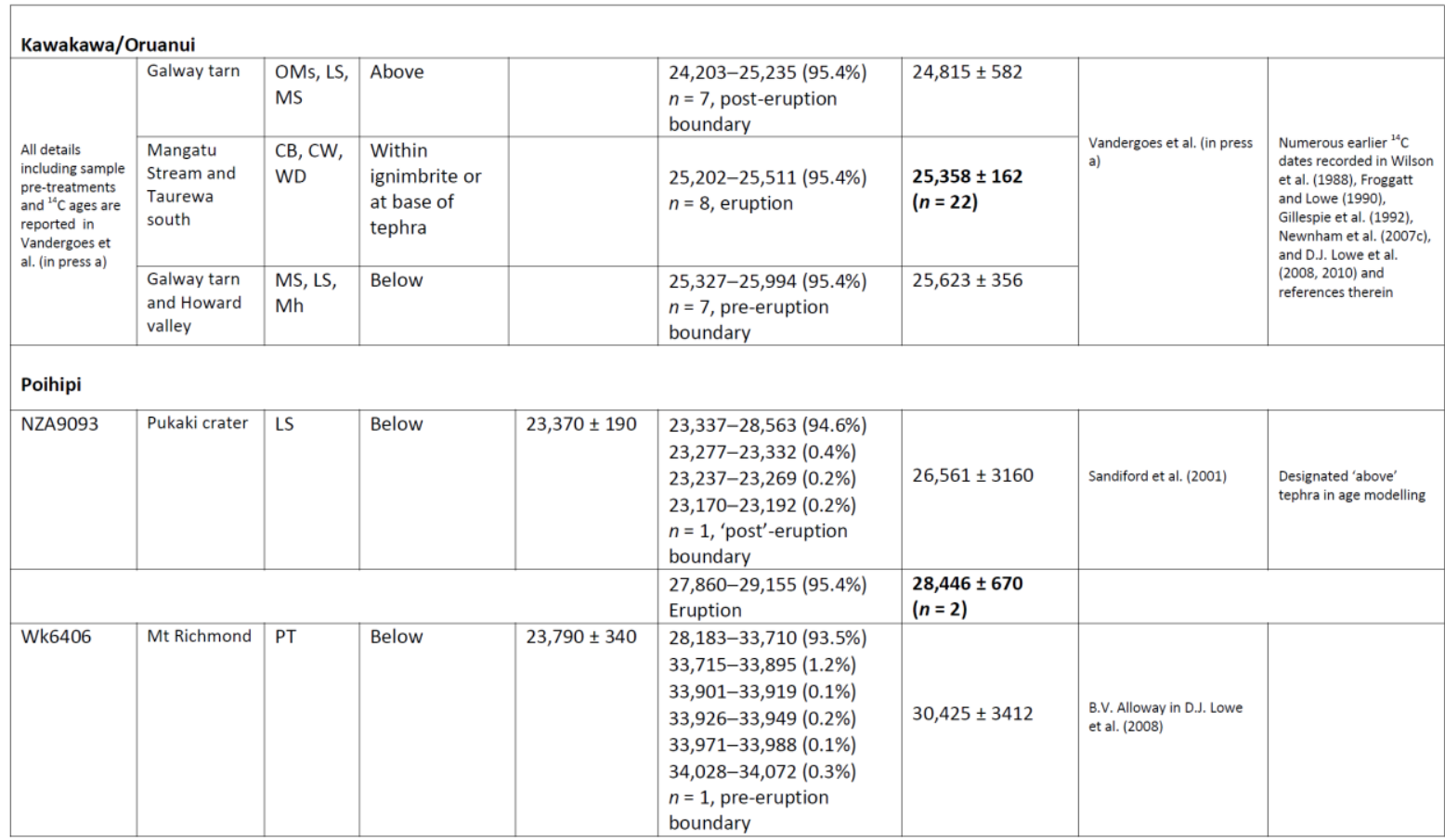

\begin{tabular}{|c|c|c|c|c|c|c|c|}
\hline \multicolumn{8}{|l|}{ Okaia } \\
\hline OZH875 & $\begin{array}{l}\text { Onepoto } \\
\text { basin }\end{array}$ & LS & Above $(10 \mathrm{~mm})$ & $22,630 \pm 180$ & $\begin{array}{l}21,483-28,229(93.7 \%) \\
21,361-21,477(0.9 \%) \\
21,228-21,283(0.4 \%) \\
21,327-21,343(0.1 \%) \\
n=1, \text { post-eruption } \\
\text { boundary }\end{array}$ & $25,316 \pm 4004$ & Molloy et al. (2009) \\
\hline & & & & & $\begin{array}{l}27,155-29,736(95.3 \%) \\
29,749-29,764(0.1 \%) \\
\text { Eruption }\end{array}$ & $\begin{array}{l}28,621 \pm 1428 \\
(n=3)\end{array}$ & \\
\hline Wk5757 & $\begin{array}{l}\text { Mt } \\
\text { Richmond }\end{array}$ & OS & Below $(10 \mathrm{~mm})$ & $25,080 \pm 230$ & \multirow{2}{*}{$\begin{array}{l}28,660-35,317(95.4 \%) \\
n=2, \text { pre-eruption } \\
\text { boundary }\end{array}$} & \multirow[t]{2}{*}{$31,070 \pm 3620$} & Sandiford et al. (2002) \\
\hline OZH876 & $\begin{array}{l}\text { Onepoto } \\
\text { basin }\end{array}$ & LS & Below $(10 \mathrm{~mm})$ & $24,570 \pm 210$ & & & \begin{tabular}{|l|} 
Molloy et al. (2009) \\
\end{tabular} \\
\hline
\end{tabular}

'Radiocarbon laboratories: Wk = Waikato, Hamilton, New Zealand; NZ, NZA = Rafter (formerly New Zealand), Lower Hutt, New Zealand; CAMS = Centre for AMS, Lawrence Livermore National Laboratory, University of California, USA; OZH, OZK = ANSTO, Canberra, Australia.

${ }^{\mathrm{b}} \mathrm{LS}$, lake sediment; $\mathrm{PT}$, peat; $\mathrm{CB}$, carbonised small branch(es); CW, carbonised wood; $\mathrm{CH}$, charcoal; WD, wood; PF, PF(Gi), planktonic foraminifera (Globorotalia inflata); $\mathrm{CHr}$, residual charcoal after humic and fulvic acid extractions; $\mathrm{CT}$, carbonised small twigs and branches; OS, organic sediment; OMs, organic matter/sphagnum; MS, macrofossil sphagnum; Mh, heath macrofossil species (Styphelioidea).

'Calibrations were made using IntCal09 (Reimer et al., 2009) after firstly subtracting $44 \pm 17$ years from conventional ${ }^{14} \mathrm{C}$ ages for the Southern Hemisphere offset (Hogg et al., 2011). Ages shown in bold are the new eruption ages (based on $n$ ages in total) that we have determined for the tephras using modelling via the Tau_Boundary function in OxCal4.1.7 (Bronk Ramsey, 2009a, 2009b), which incorporates stratigraphic information (summarised as the pre-eruption and post-eruption boundary ages for samples below and above tephras, respectively) as well as the ${ }^{14} \mathrm{C}$ age data.

${ }^{\mathrm{d}}$ Ages published pre-1990 were reported and evaluated in Hogg et al. (1987) and Froggatt and Lowe (1990).

${ }^{e}$ Tephra names from Froggatt and Lowe (1990) and D.J. Lowe et al. (2008).

fUncorrected for marine reservoir effect. 


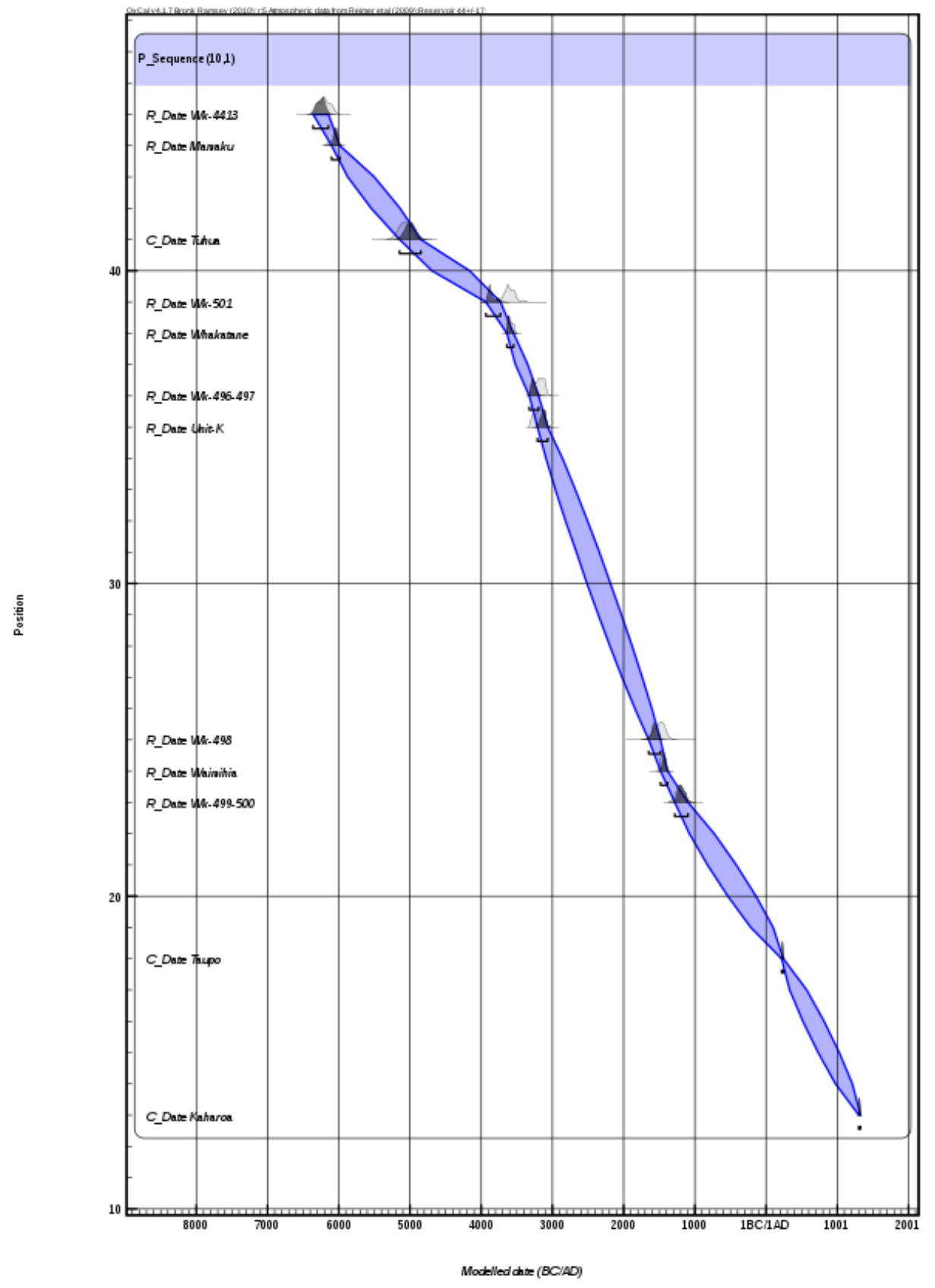

Fig. S1. Posterior age-depth models (in blue) derived using the Poisson-based $P$ _Sequence function in OxCal4.1.7 with $\mathrm{k}=10$, and IntCal09, for the upper segment $(0-50 \mathrm{~cm}$ depth, tephra-free basis) of the Kaipo bog sequence (95\% probability intervals). The complete set of underpinning ages (in ${ }^{14} \mathrm{C}$ yr BP or cal. yr BP, $\pm 1 \sigma$ ) and associated sampling depths (tephra free basis) of the Kaipo bog sequence, as modified for this paper, are given in Table S1. 


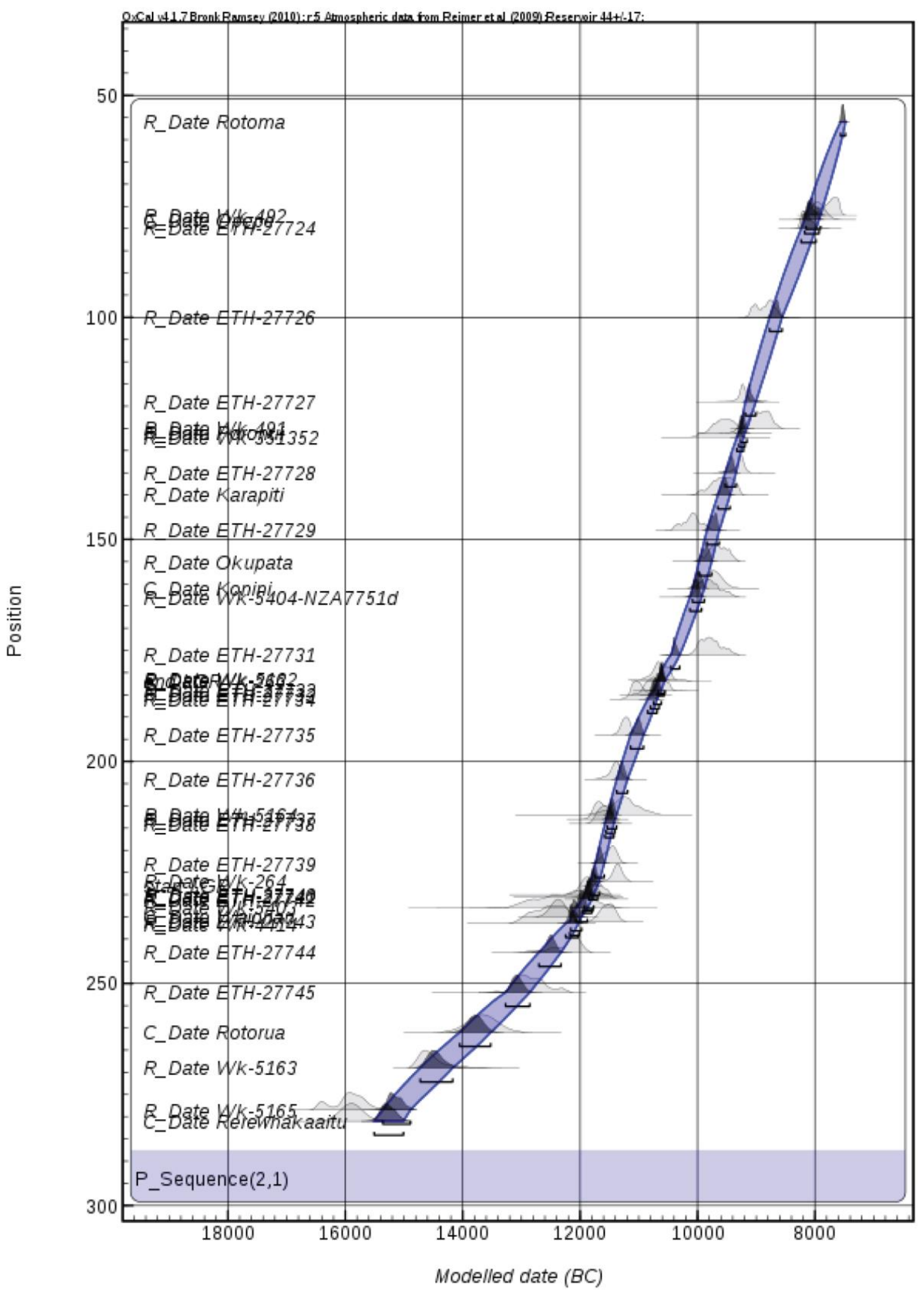

Fig. S2. Posterior age-depth models (in blue) derived using the $P \_$Sequence function in OxCal4.1.7 with $\mathrm{k}=2$, and IntCal09, for the lower segment (50-281 cm depth, tephra-free basis) of the Kaipo bog sequence (95\% probability intervals). Other details as for Fig. S1. 


\section{Table S1}

Complete set of ${ }^{14} \mathrm{C}$ or calibrated ages (all \pm 1 std dev) and associated sampling depths (tephra-free basis) of the Kaipo bog sequence as used in this paper for age modelling via Bacon and and the $P$ sequence function in OxCal4.1.7 (data modified after Hajdas et al., 2006, p.342).

\begin{tabular}{|c|c|c|c|c|c|c|}
\hline Tephra/sample & $\mathrm{Age}^{\mathrm{b}}$ & Error I & Depth & $\mathrm{cc}^{\mathrm{C}}$ & $d \cdot R^{d}$ & d.STD \\
\hline Kaharoa & 636 & $5 \mathrm{cal} 1$ & 13 & 0 & 0 & 0 \\
\hline Taupo & 1718 & $5 \mathrm{cal}$ & 18 & 0 & 0 & 0 \\
\hline$W k-499-500^{e}$ & 3000 & 33 & 23 & 1 & 44 & 17 \\
\hline Waimihia & 3230 & 20 & 24 & 1 & 44 & 17 \\
\hline Wk-498 & 3250 & 70 & 25 & 1 & 44 & 17 \\
\hline Unit-K & 4510 & 20 & 35 & 1 & 44 & 17 \\
\hline$W k-496-497^{e}$ & 4509 & 20 & 36 & 1 & 44 & 17 \\
\hline Whakatane & 4830 & 20 & 38 & 1 & 44 & 17 \\
\hline$W k-501$ & 4860 & 70 & 39 & 1 & 44 & 17 \\
\hline Tuhua & 7027 & $85 \mathrm{cal}$ & 41 & 0 & 0 & 0 \\
\hline Mamaku & 7250 & 20 & 44 & 1 & 44 & 17 \\
\hline Wk-4 413 & 7380 & 70 & 45 & 1 & 44 & 17 \\
\hline Rotoma & 8530 & 10 & 56 & 1 & 44 & 17 \\
\hline Wk-492 & 8710 & 80 & 77 & 1 & 44 & 17 \\
\hline Opepe & 9906 & $123 \mathrm{cal}$ & 78 & 0 & 0 & 0 \\
\hline ETH-27724 & 8990 & 70 & 80 & 1 & 44 & 17 \\
\hline ETH-27726 & 9510 & 70 & 100 & 1 & 44 & 17 \\
\hline ЕTH-27727 & 9795 & 75 & 119 & 1 & 44 & 17 \\
\hline Wk-491 & 9560 & 80 & 125 & 1 & 44 & 17 \\
\hline Poronui & 9840 & 60 & 126 & 1 & 44 & 17 \\
\hline$W k-351-352^{e}$ & 10024 & 93 & 127 & 1 & 44 & 17 \\
\hline ETH-27728 & 9840 & 75 & 135 & 1 & 44 & 17 \\
\hline Karapiti & 10030 & 90 & 140 & 1 & 44 & 17 \\
\hline ETH-27729 & 10290 & 70 & 148 & 1 & 44 & 17 \\
\hline Okupata & 10080 & 60 & 155 & 1 & 44 & 17 \\
\hline Konini & 11682 & $146 \mathrm{ca}]$ & 1161 & 0 & 0 & 0 \\
\hline Wk-5404/NZA7751 & 10146 & 76 & 163 & 1 & 44 & 17 \\
\hline ETH-27731 & 10140 & 75 & 176 & 1 & 44 & 17 \\
\hline Wk-5162 & 10790 & 70 & 181.5 & 1 & 44 & 17 \\
\hline$W k-263$ & 10600 & 90 & 182 & 1 & 44 & 17 \\
\hline ETH-27732 & 10640 & 75 & 184 & 1 & 44 & 17 \\
\hline ETH-27733 & 10900 & 75 & 185 & 1 & 44 & 17 \\
\hline ЕTH-27734 & 11120 & 80 & 186 & 1 & 44 & 17 \\
\hline ETH-27735 & 11320 & 80 & 194 & 1 & 44 & 17 \\
\hline $\mathrm{ETH}-27736$ & 11540 & 80 & 204 & 1 & 44 & 17 \\
\hline$W k-5164$ & 11360 & 210 & 212 & 1 & 44 & 17 \\
\hline ETH-27737 & 11800 & 80 & 213 & 1 & 44 & 17 \\
\hline ETH-27738 & 11730 & 85 & 214 & 1 & 44 & 17 \\
\hline ETH-27739 & 11620 & 85 & 223 & 1 & 44 & 17 \\
\hline$W k-264$ & 11500 & 80 & 227 & 1 & 44 & 17 \\
\hline ЕTH-27740 & 12030 & 90 & 230 & 1 & 44 & 17 \\
\hline ETH-27741 & 11940 & 85 & 230.5 & 1 & 44 & 17 \\
\hline ETH-27742 & 11830 & 85 & 231 & 1 & 44 & 17 \\
\hline$W k-5403$ & 12180 & 260 & 233 & 1 & 44 & 17 \\
\hline Waiohau & 14324 & $127 \mathrm{cal}$ & 1235 & 0 & 0 & 0 \\
\hline ETH-27743 & 11660 & 100 & 236 & 1 & 44 & 17 \\
\hline Wk-4414 & 12420 & 90 & 236.5 & 1 & 44 & 17 \\
\hline ETH-27744 & 12240 & 85 & 243 & 1 & 44 & 17 \\
\hline
\end{tabular}




$\begin{array}{lrlrrrr}\text { ETH-27745 } & 12610 & 85 & 252 & 1 & 44 & 17 \\ \text { Rotorua } & 15612 & 253 \mathrm{cal} & 261 & 0 & 0 & 0 \\ \text { Wk-5163 } & 13420 & 80 & 269 & 1 & 44 & 17 \\ \text { Wk-5165 } & 14700 & 160 & 278.5 & 1 & 44 & 17 \\ \text { Rerewhakaaitu } & 17845 & 190 \mathrm{cal} & 281 & 0 & 0 & 0\end{array}$

${ }^{a}$ Wk, Waikato Radiocarbon Dating Laboratory (New Zealand); ETH, ETH/PSI AMS Radiocarbon Dating Laboratory, Zurich (Switzerland) (see also Fig. 2) ${ }^{\mathrm{b}} \mathrm{All}$ in ${ }^{14} \mathrm{C}$ yr BP except those marked as calibrated (cal) yr BP (see paper) ${ }^{\mathrm{C} U s e}$ of IntCalo9 (1) or not (0) for those ages already calibrated (cal) ${ }^{\mathrm{d} C o r r e c t i o n}$ for SH offset $-44 \pm 17 \mathrm{yr}$ (Hogg et al., 2011). For example, a conventional radiocarbon age of $20,000 \pm 100{ }^{14} \mathrm{C}$ yr BP becomes $19,956 \pm$ $101{ }^{14} \mathrm{C}$ yr BP after $\mathrm{SH}$ offset correction, the new error term (101 yr) being the square root of $\left[100^{2}+17^{2}\right]$

etwo ages on same tephra combined by Hajdas et al. (2006)

fDual sample number; note NZA7751 was misreported in Lowe et al. (1999) as NZA7761 